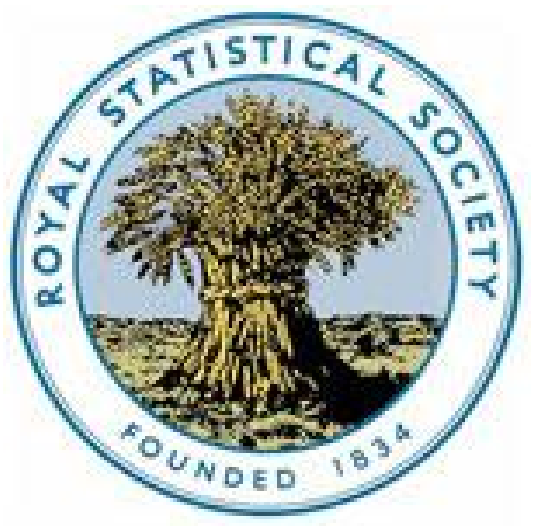

\title{
WILEY
}

\section{Local Taxation in London}

Author(s): Laurence Gomme

Source: Journal of the Royal Statistical Society, Vol. 61, No. 3 (Sep., 1898), pp. 442-517

Published by: Wiley for the Royal Statistical Society

Stable URL: http://www.jstor.org/stable/2979648

Accessed: 25-06-2016 07:08 UTC

Your use of the JSTOR archive indicates your acceptance of the Terms \& Conditions of Use, available at

http://about.jstor.org/terms

JSTOR is a not-for-profit service that helps scholars, researchers, and students discover, use, and build upon a wide range of content in a trusted digital archive. We use information technology and tools to increase productivity and facilitate new forms of scholarship. For more information about JSTOR, please contact support@jstor.org.

Royal Statistical Society, Wiley are collaborating with JSTOR to digitize, preserve and extend access to Journal of the Royal Statistical Society 


\section{Local Taxation in London. By G. Laurence Gomme.}

[Read before the Royal Statistical Society, 17th May, 1898.

A. E. Batrman, Esq., C.M.G., in the Chair.]

The primary fact which governs the amount of local taxation is the expenditure of local government authorities. In London this expenditure is incurred by four county authorities, sixteen district authorities, seventeen union authorities, thirty-four special district authorities and $33 \mathrm{I}$ parish authorities. The total expenditure incurred in London in 1895-96 by these several authorities was as follows:-

1. County Authorities-

London County Council

School Board for London

Metropolitan Asylums Board

police

2. District Authorities-

City of London Corporation

„Commissioners of Sewers

District boards (12)

Library commissioners (2)

3. Union Authorities-

Boards of guardians (17)

4. Special District Authorities-

Sick asylum district managers (2)

School district managers (6)

Library commissioners (1).

Wards of the City of London (25)

5. Parish Authorities-

Vestries (29) and 1 local board

Boards of guardians (14)

Overseers or bodies acting as overseers (192)

Library commissioners (27)

Baths commiseioners (29)

Burial boards (29)

Market trustees (1)

Churchwardens (9)

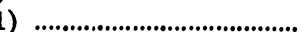

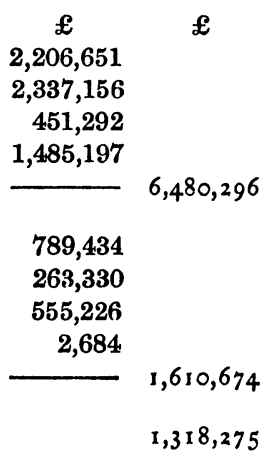

451,292

$1,485,197$

$$
6,480,296
$$

789,434

268,330

555,226

2,684

$1,610,674$

$1,318,275$

32,589

122,432

2,570

6,931

164,522

$1,938,641$

$1,163,851$

200,149

59,135

137,093

55,523

8,076

9,899

Total expenditure which governs the amount of local taxation.

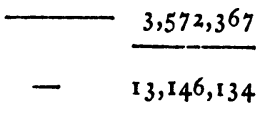


This expenditure is for the following purposes:-

\begin{tabular}{|c|c|c|c|}
\hline Purpose. & $\begin{array}{l}\text { Local Authority } \\
\text { incurring Expenditure. }\end{array}$ & \multicolumn{2}{|c|}{ Amount. } \\
\hline $\begin{array}{l}\text { Maintenance of the poor } \\
\text { in workhouses, \&c. }\end{array}$ & $\begin{array}{l}\text { Metropolitan Asylums Board } \\
\text { Boards of guardians .................. } \\
\text { Sick asylum district managers } \\
\text { School district managers }\end{array}$ & $\begin{array}{r}\mathfrak{E} \\
\mathbf{3 4 2 , 9 9 3} \\
1,549,332 \\
27,050 \\
90,287\end{array}$ & \\
\hline $\left.\begin{array}{c}\text { Maintenance of the } \\
\text { poor (outdoor) }\end{array}\right\}$ & Boards of guardians & 一 & $\begin{array}{r}2,209,662 \\
261,069^{\circ}\end{array}$ \\
\hline Maintenance of lunatics & 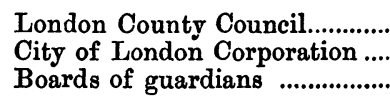 & $\begin{array}{r}59,469 \\
2,464 \\
360,4,10\end{array}$ & \\
\hline Education .............................. & 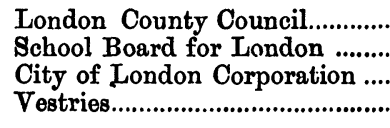 & $\begin{array}{r}76,560 \\
1,851,704 \\
63,426 \\
495\end{array}$ & \\
\hline $\begin{array}{cc}\text { Roads, dust } & \text { removal, } \\
\text { bridges, } & \text { embank- } \\
\text { ments, \&c. } & \end{array}$ & $\begin{array}{l}\text { London County Council............. } \\
\text { City of London Corporation ... } \\
\text { " Commissioners of Sewers } \\
\text { Vestries and district boards .... }\end{array}$ & $\begin{array}{r}38,124 \\
26,635 \\
94,562 \\
1,377,600\end{array}$ & 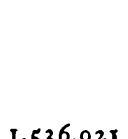 \\
\hline Sewerage and drainage.... & $\begin{array}{l}\text { London County Council.............. } \\
\text { City Commissioners of Sewers } \\
\text { Vestries and district boards .... }\end{array}$ & $\begin{array}{r}185,065 \\
17,252 \\
185,368\end{array}$ & \\
\hline Public health ......................... & 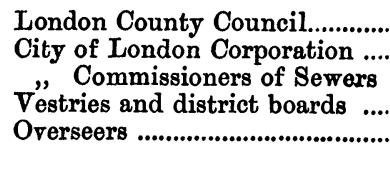 & $\begin{array}{r}20,696 \\
13,201 \\
7,947 \\
80,310 \\
110\end{array}$ & 122,26 \\
\hline Lighting ............................... & 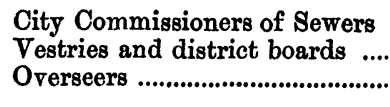 & $\begin{array}{r}21,906 \\
253,595 \\
189\end{array}$ & 27560 \\
\hline Police and magistracy .... & $\begin{array}{l}\text { London County Council.............. } \\
\text { Metropolitan police................... } \\
\text { City of London Corporation.... }\end{array}$ & $\begin{array}{r}98,260 \\
1,413,767 \\
185,982\end{array}$ & \\
\hline Fire Brigade .......................... & London County Council.............. & - & 153,827 \\
\hline $\begin{array}{l}\text { Parks, gardens, and open } \\
\text { spaces }\end{array}$ & 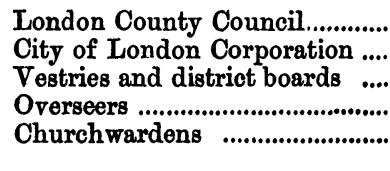 & $\begin{array}{r}107,042 \\
10,032 \\
17,522 \\
605 \\
477\end{array}$ & \\
\hline
\end{tabular}




\begin{tabular}{|c|c|c|c|}
\hline Purpose. & $\begin{array}{c}\text { |Local Authority } \\
\text { incurring Expenditure. }\end{array}$ & \multicolumn{2}{|c|}{ Amount. } \\
\hline Other ordinary services & 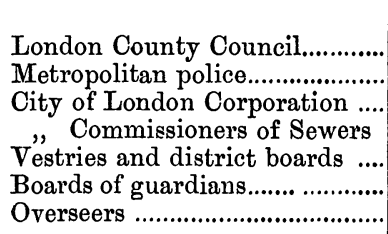 & $\begin{array}{r}\qquad \\
82,412 \\
29,282 \\
146 \\
8,331 \\
27,736 \\
411,453 \\
64,186\end{array}$ & $£$ \\
\hline Loans for all services ... & - & - & $2,81_{5}, 018$ \\
\hline $\left.\begin{array}{c}\text { Establishment for all } \\
\text { services where not } \\
\text { separately charged }\end{array}\right\}$ & - & - & 660,591 \\
\hline Special services ....................... & 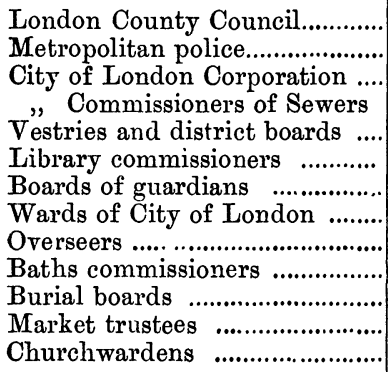 & $\begin{array}{r}6,695 \\
23,789 \\
151,780 \\
5,631 \\
25,979 \\
50,815 \\
2,536 \\
6,931 \\
4,625 \\
85,885 \\
40,517 \\
7,041 \\
9,422\end{array}$ & \\
\hline & & & $3,146,134$ \\
\hline
\end{tabular}

It should be noted here that the amount stated as expenditure of the Metropolitan police is the apportioned amount between London and extra-London of the total expenditure of the Metropolitan police authorities, the basis of the apportionment being rateable value. This can only be regarded as approximately correct. The expenditure incurred on behalf of London in respect of the police may be less or greater than the proportion based upon rateable value, but as the actual expenditure is not ascertainable, this proportion is the best means of reducing the total to a London figure.

This total expenditure $\left(13, \mathrm{I}_{4} 6, \mathrm{I}_{3} l_{l}\right.$.) does not fall wholly upon taxation. A portion of it is met by certain receipts-in-aid, and a portion is defrayed out of revenue from municipal property. Taxation is therefore relieved by the amount of these two items of receipt. They are as follows:- 


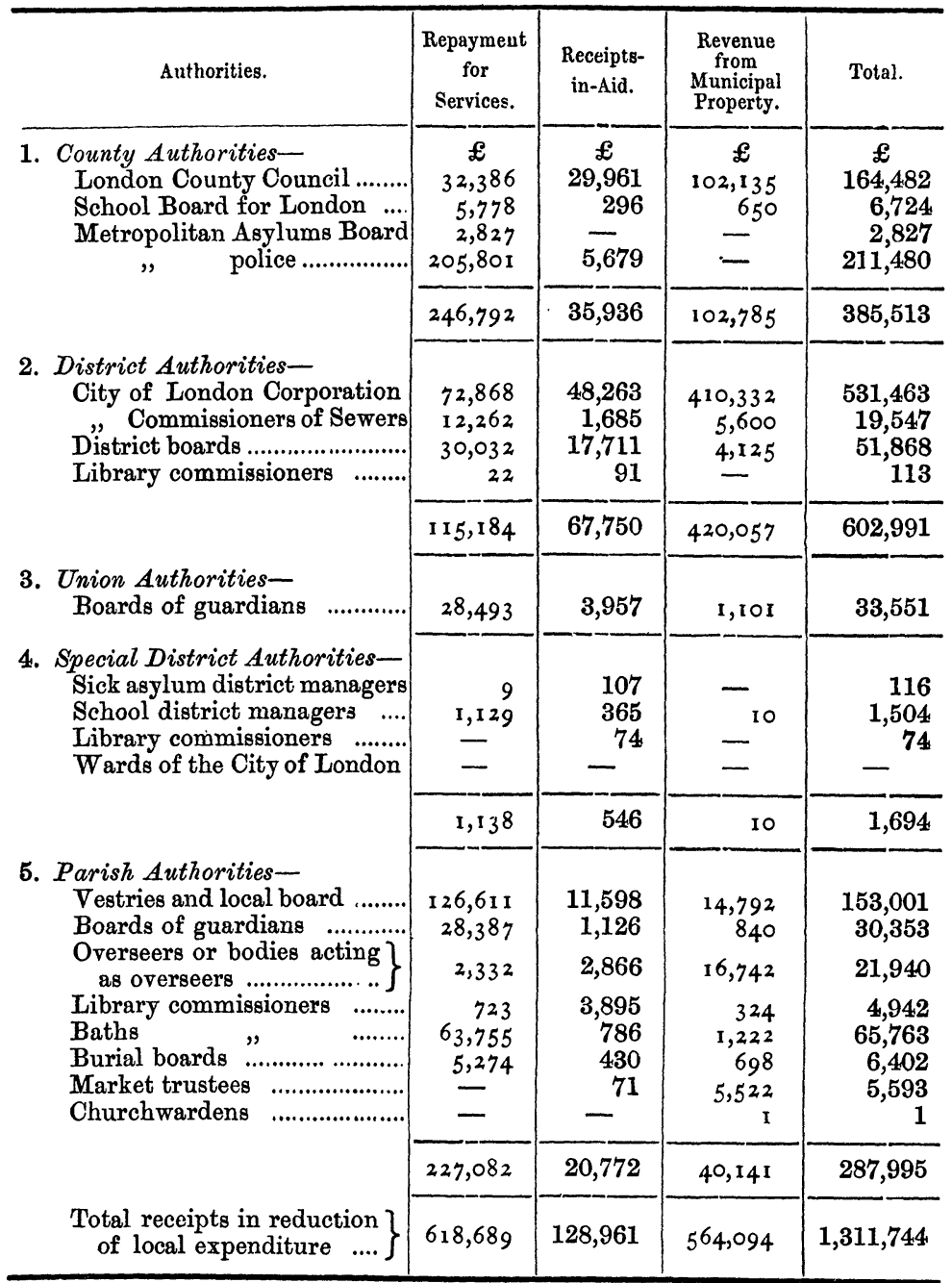

The comparative value of these several receipts is not brought out by the amounts in money, but can best be shown by reducing them to percentages of rateable values of the areas administered by the several authorities concerned. This is done in the following table :- 


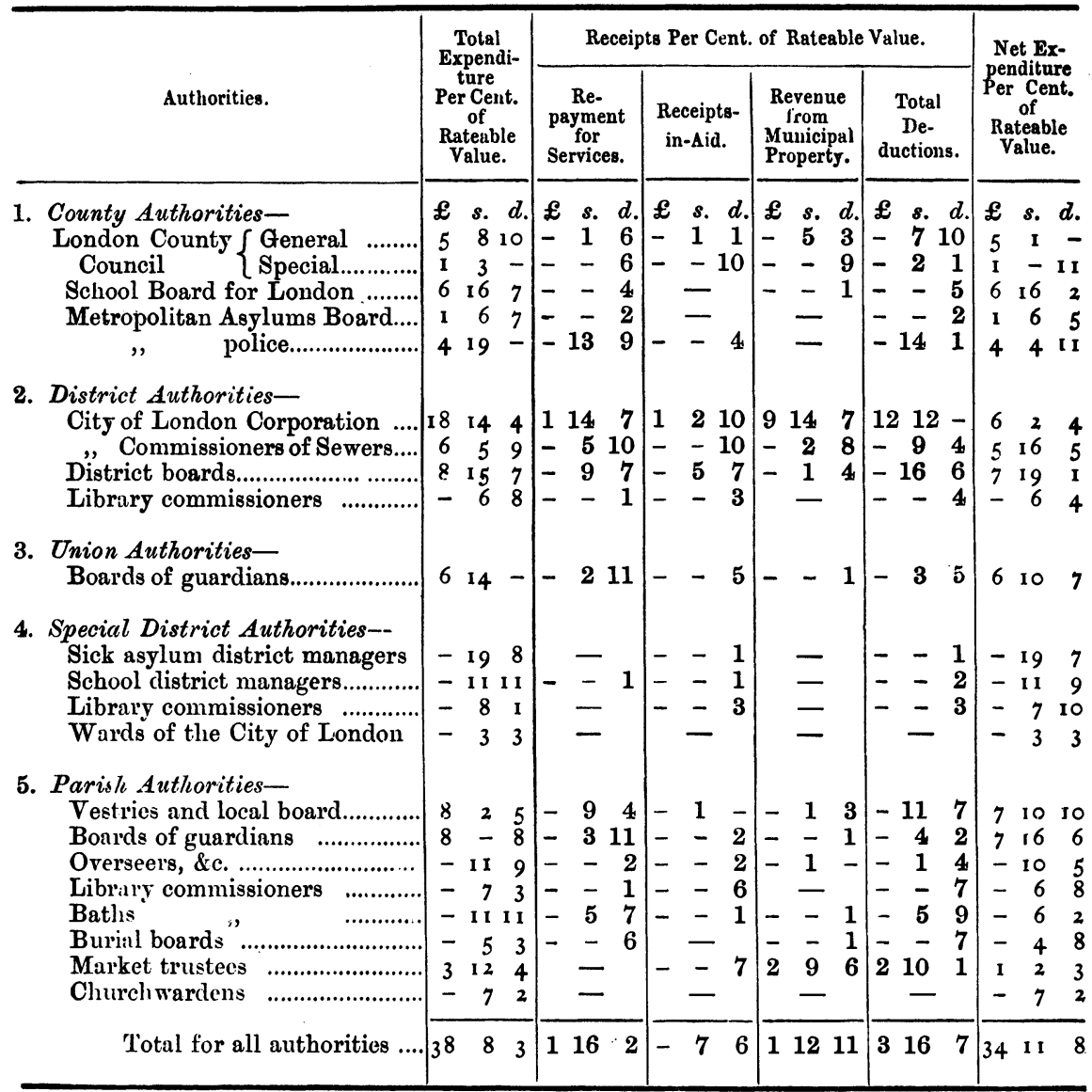

Although the largest total is in respect of repayments for services, this is not the most important item. It is largest in the city of London, where the school fees of the city schools make a very considerable item. With this exception the items are small, and consist of various services paid for by relatives of painers for their keep, in the case of guardians, by householders and others for opening ground and connecting gas, water, and other pipes in the case of vestries and district boards, employment of police by private firms, and so on.

The principal head of receipt is revenue from municipal property, the largest amounts of which are received by the City of London Corporation, the London County Council, the City Commissiouers of Sewers, the vestries and the overseers. Tho 
property belonging to the city corporation is partly municipal property which can be used for any purpose determined by the corporation, and partly trust property which can only be applied to certain specific purposes. The receipts under each of these heads are as follows-

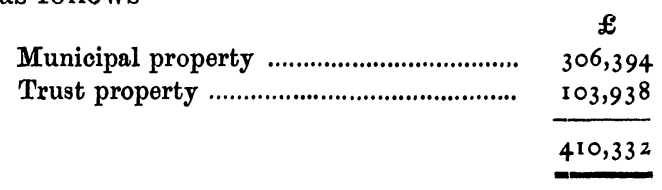

These receipts in aid of taxation are of two different kinds, which it is of importance to note in connection with the economic results of taxation. The receipts from ancient city and parish property, and from fees, fines, \&c., are not relative to expenditure, that is to say, they are not a lessening of expenditure, but rather independent receipts which lessen taxation. On the other hand, the receipts from municipal property held as products of local improvements, and receipts for services rendered are relative to expenditure, and, therefore, strictly speaking, result in a lessening of expenditure before it becomes a charge upon taxation. There are therefore two classes of receipts, as follows :-

$\begin{array}{crc} & & £ \\ \text { (a.) Receipts which lessen expenditure.... } & 618,689 \\ \text { (b.) } & 6 \quad \text { reduce taxation ......... } & 693,055 \\ & & 1,311,744 \\ & & \end{array}$

The balance of expenditure which fell upon taxation in the year 1895-96 may with these figures be summarised as follows :-

\begin{tabular}{|c|c|}
\hline 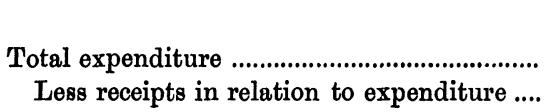 & $\begin{array}{r}£ \\
13,146,134 \\
618,689\end{array}$ \\
\hline $\left.\begin{array}{c}\text { Expenditure primarily to be met by taxation } \\
\text { Less receipts from city and parish pro- } \\
\text { perty, and from receipts-in-aid, which } \\
\text { relieve taxation }\end{array}\right\}$ & $\begin{array}{r}\text { I 2,527,445 } \\
693,055\end{array}$ \\
\hline Expenditure finally to be met by taxation.... & $11,834,390$ \\
\hline
\end{tabular}

This expenditure was incurred by the several authorities as follows :-

1. County Authorities-

London County Council

School Board for London

Metropolitan Asylums Board ....

," police

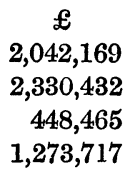

$£$ 
2. District Authorities-

City of London Corporation.........

"Commissioners of Sewers ....

District boards

Library commissioners

3. Union Authorities-

Boards of guardians

4. Special District Authorities-

Sick asylum district managers ....

School district managers

Library commissioners

Wards of the city

5. Parish Authorities-

Vestries and local board

Boards of guardians

Overseers or bodies acting as overseers

Library commissioners

Baths commissioners .

Burial boards

Market trustees

Churchwardens

$\left.\begin{array}{c}\text { Total expenditure falling } \\ \text { upon taxation...................... }\end{array}\right\}$
$1,785,640$

$1,133,498$

178,209

54,193

71,330

49,121

2,483

9,898
$£$

257,971

243,783

503,358

$£$

2,571

$1,007,683$

I, 284,724

32,473

120,928

2,496

6,931

I 62,828

$-\frac{3,284,372}{11,834,390}$

The taxation to meet this expenditure is divided into three classes. First, there is an amount appropriated to local taxation from imperial taxes, which amount is applied to local expenditure before such expenditure is sent down upon local taxation proper; secondly, there are certain indirect local taxes levied independently of what the local expenditure may be, and applied to such expenditure before it is sent down upon direct taxation; and thirdly, there is the final balance of expenditure left over after these operations, which is the measure of the direct taxation. The amount of this direct taxation is therefore, as a matter of fact, determined by the amount of expenditure thus left over. Of the three divisions of local taxation, the first, appropriations from imperial taxes, and the second, local indirect taxation, are fixed according to rules, independent of municipal expenditure, that is, upon rules sanctioned by Parliament and not determined by the local authorities; while the third division only, direct taxation, is governed by the amount of municipal expenditure, and is under the control of local anthorities. The total taxation is a measure of the municipal expenditure, but direct taxation alone bears the pressure of increased or receives the benefit of decreased municipal expenditure.

In the yeap 1895-96 the local expenditure in London was met by each of the three classes of taxation as follows:- 
A. Appropriations from Imperial taxes-

London County Council

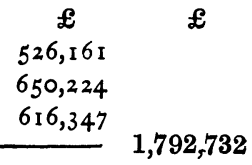

B. Indirect local taxation-

School Board for London

County taxation-

London County Council ........ $\quad \mathbf{7 6 , 2 1 9}$

Metropolitan police ................. 28,815

City of London Corporation $\quad 134,282$

District taxation-

City Commissioners of Sewers $\quad 8,117$

District boards.

208

Special district taxation-

Market trustees

239,3 I 6

Vestries and local board

Overseers

Burial boards

37,578

o. Direct local taxation-

County rating-

London County Council

School Board for London

Metropolitan Asylums Board....

$$
\text { " police }
$$

Local Government Board

$2,952,322$

$1,631,612$

422,982

625,072

$1,174,680$

District rating-

City of London Corporation ....

„Commissioners of Sewers

District boards

78,848

252,877

337,996

Library commissioners

2,494

Union rating-

Boards of guardians

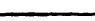

Special district rating-

Sick asylum district managers

School district managers.

Library commissioners.

Wards of the city

.................

rish rating -

Vestries and local board.

Boards of guardians

Overseers

Library commissioners

Baths commissioners

Burial boards

1,085

120,965

2,658

6,965

$$
\text { I6I,673 }
$$

$1,060,645$

$\mathbf{3 7 1 , 7 0 6}$

225,556

53,479

78,023

12,755

Churchwardens. 
I will now proceed to explain these different classes of taxation. The appropriations from imperial taxation include the sum collected in London from local licences, amounting to $438,644 l$, and certain apportioned amounts of imperial taxation as follows :-

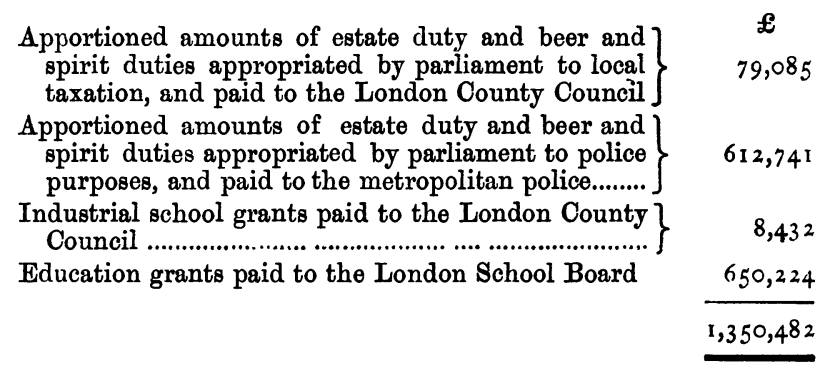

The first of these apportioned items is arrived at by deducting the amount paid to the metropolitan police from the amount of these duties appropriated to London. This is not strictly in accord with the terms of the Local Government Act, 1888, which provides for the amount paid to the metropolitan police being deducted from the total appropriation to London of imperial taxes, i.e., the above named duties together with the local licences. But inasmuch as the local licences are collected in London only, the incidence of this taxation falls upon London, and it is more correct from the point of view of taxation, to make the deduction for the police from the amount strictly appropriated from imperial taxation, leaving the local licences entirely for the use of London.

The first point to note about these appropriations of imperial taxation to local services is the diverse methods adopted, and the extraordinary complications which are produced between imperial and local finance. There are two additional matters which help to further complicate this relationship, namely, the appropriation to imperial purposes from the local taxation account of the cost of swine fever under the Diseases of Animals Act, 1894, and the grants under the Agricultural Rates Act, 1896. The first of these does not occur in the local taxation I am dealing with, because the expenditure is incurred by Government and paid for out of local taxation; the second does not occur because it did not come into operation until the year after that to which my figures relate. But for a proper consideration of these imperial grants to local taxation these matters must be included.

At present then there are no less than six methods of allocating imperial taxation to the relief of local rates. They are as follows :-

1. Licences, according to the amount collected within the 
county or county borough areas, subject to an apportionment between counties and county boroughs under Section 32 of the Local Government Act, 1888.

2. Estate duty and customs and excise duties, according to the grants from imperial taxation actually made to the several local authorities within the county and county borough areas in the year 1887-88, but subject to special adjustment in one or two cases.

3. Police pension grant, according to an arbitrary decision of parliament founded on no basis beyond the immediate requirements of the London police.

4. Education grant, according to the results of education.

5. The cost of the Diseases of Animals Act, 1894, administered by the Board of Agriculture, an imperial department, and paid for out of the local taxation account, that is to say, paid for by the counties and county boroughs in proportion to the basis of apportionment under No. 2, with which it has nothing whatever to do, and not in proportion to the expenditure incurred.

6. The grants under the Agricultural Rates Act, 1896, according to the amount of rates paid upon agricultural lands.

The first method, that of appropriating local taxes collected in the county to the services of the county, is prima facie a perfectly sound system.

The second method is arbitrary and not founded upon any principle of taxation which can be defended.

The discontinued grants which form the basis of this apportionment for London comprise the payments towards the cost incurred by guardians and other bodies in respect of lunatics, disturnpiked roads, salaries of poor law medical officers and teachers in poor law schools, payments to registrars of births and deaths, public vaccinators, medical officers and sanitary inspectors, the cost of criminal prosecutions, and of the metropolitan police.

The amount certified by the Local Government Board as the estimated receipts by London from the discontinued grants in 1887-88, was :-

\begin{tabular}{|c|c|}
\hline \multicolumn{2}{|l|}{ 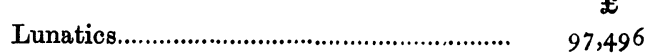 } \\
\hline Poor Law medical officers & $\begin{array}{l}91,490 \\
32,939\end{array}$ \\
\hline Teachers in Poor Law schools ...................... & 12,513 \\
\hline Registrars of births and deaths.................. & 584 \\
\hline Vaccinators & 2,030 \\
\hline 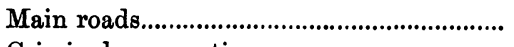 & 3,559 \\
\hline 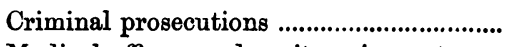 & 21,384 \\
\hline Medical officers and sanitary inspectors & \\
\hline Police & $45 \%, 579$ \\
\hline & 628,084 \\
\hline
\end{tabular}


These figures differ in amount from those given in the parliamentary return (C-5424, pp. 24 and 25) issued from the Local Government Board on 21st June, 1888, where the total appears at $623,917 l$.

These figures contain the local charges, and certain charges which have to be apportioned as between (1) Penge and Croydon, (2) the new county of London and the old counties, and (3) the new county of London and the police area. The apportionment was based upon rateable value, and a critical examination of the government certified figures is desirable. In a return (see "London Statistics," vol. iv, p. 569) an analysis of the receipts from grants in 1887-88 according to the published local taxation returns was given, the necessary apportionments being based on the rateable values in force for that year. The result showed a difference when compared with the figures given in the certificate of the Local Government Board; but not perhaps of sufficient importance to affect the question under consideration. ${ }^{1}$ Adjusting these differences, the following might be taken as the analysis of the government certificate :-

\begin{tabular}{|c|c|c|c|c|}
\hline \multirow{12}{*}{ 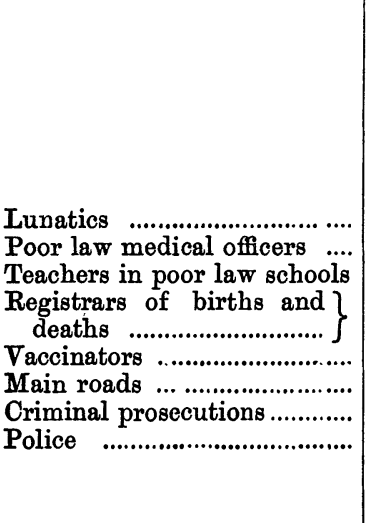 } & \multirow{2}{*}{$\begin{array}{c}\text { Paid to } \\
\text { Local } \\
\text { Authorities } \\
\text { in } \\
\text { London. }\end{array}$} & \multicolumn{2}{|c|}{$\begin{array}{l}\text { Paid to County Authorities and } \\
\text { apportioned to London. }\end{array}$} & \multirow{2}{*}{$\begin{array}{c}\text { Total } \\
\text { Grants. }\end{array}$} \\
\hline & & For Penge. & $\begin{array}{l}\text { For County and } \\
\text { other Areas. }\end{array}$ & \\
\hline & $£$ & $£$ & $£$ & $£$ \\
\hline & 92,018 & 276 & 5,202 & 97,496 \\
\hline & 32,793 & 146 & - & 32,939 \\
\hline & 12,513 & - & - & $12,5^{1} 3$ \\
\hline & 584 & - & - & $5^{84}$ \\
\hline & 2,030 & - & - & 2,030 \\
\hline & 3,559 & - & - & 3,559 \\
\hline & ],321 & - & 20,063 & 21,384 \\
\hline & - & - & 457,579 & 457,579 \\
\hline & 144,818 & 422 & 482,844 & 628,084 \\
\hline
\end{tabular}

The construction of this table enables us to apportion the figures of previous years upon the same basis, and the following table shows the amounts received by London from imperial grants

1 I have not had access to the government figures, but the printed analysis given in the local taxation returns has been used. Differences might occur owing to the published accounts containing the receipts in the year instead of the receipts for the year; that is, taking into account balances of a previous year paid in the year and balances for the year owing at the end. It has been assumed that the government certificate includes the necessary allowances in respect of Penge, but there is nothing to prove this. 
in the five years to $1887-88$, as compared with the amount certified in that year:-

\begin{tabular}{|c|c|c|c|c|c|}
\hline \multirow{2}{*}{ Year. } & \multirow{2}{*}{$\begin{array}{c}\text { Charges in respect of } \\
\text { which the Government Grants } \\
\text { were made. }\end{array}$} & \multicolumn{2}{|c|}{ London. } & \multicolumn{2}{|c|}{ Rest of England. } \\
\hline & & $\begin{array}{l}\text { Amount } \\
\text { Received. }\end{array}$ & $\begin{array}{l}\text { Per- } \\
\text { centage. }\end{array}$ & $\begin{array}{l}\text { Amount } \\
\text { Received. }\end{array}$ & $\begin{array}{c}\text { Per- } \\
\text { centage. }\end{array}$ \\
\hline $1883-84$ & $\left.\begin{array}{c}\text { Union and county luna- } \\
\text { tics, poor law officers, } \\
\text { main roads, criminal } \\
\text { prosecutions, police, } \\
\text { \&c. }\end{array}\right\}$ & $\begin{array}{c}£ \\
558,243\end{array}$ & $22 \cdot 57$ & $\begin{array}{c}£ \\
1,915,183\end{array}$ & $77^{\circ} 43$ \\
\hline $\begin{array}{l}' 84-85 \\
\text { ' } 85-86 \\
', 86-87 \\
', 87-88\end{array}$ & $\begin{array}{ll}\text { Ditto } \\
\text { Ditto }\end{array}$ & $\begin{array}{r}576,140 \\
596,574 \\
597,805 \\
* 618,984\end{array}$ & $\begin{array}{l}23 \cdot 51 \\
23 \cdot 94 \\
23 \cdot 13 \\
21 \cdot 95\end{array}$ & $\begin{array}{l}1,874,426 \\
1,895,791 \\
1,987,137 \\
2,200,775\end{array}$ & $\begin{array}{l}76 \cdot 49 \\
76.06 \\
76 \cdot 87 \\
78 \cdot 05\end{array}$ \\
\hline '87-88 & $\left.\begin{array}{c}\text { Certificate by the } \\
\text { government }\end{array}\right\}$ & 628,084 & $21 \cdot 96$ & $2,232,300$ & $78 \cdot 04$ \\
\hline
\end{tabular}

* This is exclusive of $2,530 l$. for vaccinators, which, not being included in the years $1883-84$ to $1886-87$, is not included in $1887-88$ for the purposes of this comparative table.

The certificate includes an amount for vaccinators which, not being paid to local authorities, is not given in the Local Taxation Returns $;^{2}$ it also contains adjustments made under the provisions of the Local Government Act, which are not amounts paid. These would partly account for the difference in amount between the $618,984 l$. actually paid in $1887-88$ and the $628,084 l$. certified; but they did not materially alter the ratio between London and the rest of England.

From the figures it would appear that the year 1887-88 was an unfortunate year so far as London is concerned, to have been chosen as the basis, because, in respect of the grants then certified, London received more than I per cent. less in proportion than it did in the three prior years.

The acceptance of this basis is to fix upon the cost in one year of certain specified charges as the ratio of apportionment of receipts for all future years and for all requirements.

A detailed criticism of the discontinued grants as certified will show the anomalies. The grants may be divided as follows :-

(i) Grants which London shared in full proportion to the rest of the country; namely, those in respect of poor law and criminal prosecutions.

(ii) Grants as to which London was at great disadvantage

2 These payments are set out in the reports of the Local Government Board, but not arranged as between London and the rest of England. 
with respect to the rest of the country; namely, main roads.

(iii) Grants in which London had no share whatever; namely, medical officers and sanitary inspectors.

(iv) Grants in respect of the police.

The grants under the first head (poor law, \&c.) show the following proportions :-

\begin{tabular}{|c|c|c|c|c|}
\hline & \multicolumn{2}{|c|}{ London. } & \multicolumn{2}{|c|}{ Rest of Country. } \\
\hline & Amount. & Per Cent. & Amount & Per Cent. \\
\hline $\begin{array}{r}1883-84 \ldots . . . . \\
' 84-85 . . . . . . \\
' 85-86 \ldots . . . . \\
' 86-87 \ldots . . . . . \\
' 87-88 \ldots . . . . .\end{array}$ & $\begin{array}{c}\mathscr{E} \\
145,757 \\
156,032 \\
165,797 \\
155,456 \\
164,860\end{array}$ & $\begin{array}{l}16 \cdot 67 \\
18 \cdot 98 \\
19.74 \\
18 \cdot 25 \\
19.66\end{array}$ & $\begin{array}{c}£ \\
728,347 \\
665,855 \\
674,231 \\
696,290 \\
673,879\end{array}$ & $\begin{array}{l}83 \cdot 33 \\
81 \cdot 02 \\
80 \cdot 26 \\
81 \cdot 75 \\
80^{\circ} 34\end{array}$ \\
\hline
\end{tabular}

The grants under the second head (main roads) show the following proportions :-

\begin{tabular}{|c|c|c|c|c|}
\hline & \multicolumn{2}{|c|}{ London. } & \multicolumn{2}{|c|}{ Rest of Country. } \\
\hline & Amount. & Per Cent. & Amount. & Per Cent. \\
\hline $\begin{array}{r}1883-84 . . . . . . . \\
' 84-85 \ldots . . . . \\
' 85-86 \ldots . . . . \\
' 86-87 \ldots . . . . . \\
' 87-88 \ldots . . . . .\end{array}$ & \begin{tabular}{c}
\multicolumn{1}{c}{$£$} \\
1,975 \\
1,524 \\
1,731 \\
1,760 \\
3,559
\end{tabular} & $\begin{array}{l}1.00 \\
0.73 \\
0.76 \\
0.74 \\
0.72\end{array}$ & $\begin{array}{c}£ \\
194,898 \\
206,097 \\
227,366 \\
236,291 \\
490,870\end{array}$ & $\begin{array}{l}99^{\circ} 00 \\
99^{\circ} 27 \\
99^{\circ} 24 \\
99^{\circ} 26 \\
99^{\circ} 28\end{array}$ \\
\hline
\end{tabular}

The grant under the third head (salaries of medical officers of health and inspectors of nuisances) were as follows :-

\begin{tabular}{|c|c|c|c|c|}
\hline & \multicolumn{2}{|c|}{ London. } & \multicolumn{2}{|c|}{ Rest of Country. } \\
\hline & Amount. & Per Cent. & Amount. & Per Cent. \\
\hline $\begin{array}{r}1883-84 \ldots . . . . . \\
' 84-85 \ldots . . . . \\
' 85-86 . . . \ldots . . \\
' 86-87 \ldots . . . . \\
' 87-88 . . . . . .\end{array}$ & $\begin{array}{c}£ \\
\text { Nil } \\
, \\
, \\
, \\
,\end{array}$ & $\frac{-}{-}$ & $\begin{array}{c}£ \\
67,926 \\
76,814 \\
69,113 \\
75,419 \\
73,804\end{array}$ & $\begin{array}{l}100 \\
100 \\
100 \\
100 \\
100\end{array}$ \\
\hline
\end{tabular}

The grants under the fourth head (police) show the following proportions :- 


\begin{tabular}{|c|c|c|c|c|}
\hline & \multicolumn{2}{|c|}{ London. } & \multicolumn{2}{|c|}{ Rest of Country. } \\
\hline & Amount. & Per Cent. & Amount. & Per Cent. \\
\hline 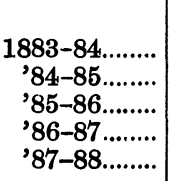 & $\begin{array}{c}£ \\
410,511 \\
418,584 \\
429,046 \\
440,589 \\
450,565\end{array}$ & $\begin{array}{l}30 \cdot 76 \\
31 \cdot 14 \\
31 \cdot 68 \\
31 \cdot 03 \\
31 \cdot 90\end{array}$ & $\begin{array}{c}£ \\
924,012 \\
925,660 \\
925,081 \\
979,137 \\
962,222\end{array}$ & $\begin{array}{l}69 \cdot 24 \\
68 \cdot 86 \\
68 \cdot 32 \\
68 \cdot 97 \\
68 \cdot 10\end{array}$ \\
\hline
\end{tabular}

From these tables it is obvious that London is at a special disadvantage with reference to main roads and sanitation, and yet these are services in which, perhaps more than any other, the country at large is greatly interested. That the traffic of London for commercial and other purposes should be assisted by the best means of communication is one of the most important of London necessities, and at the same time one in respect of which it receives the least assistance from imperial taxation. ${ }^{3}$

The peculiar operation of the exchequer contribution for police purposes deserves special attention. Previous to 1888 it was a sum equal to $4 d$. in the $£$ on the rateable value of the metropolitan police district, an amount which increased annually with the growth of rateable value. But in 1888 the exchequer grants to the county of London became a fixed proportion of a total sum, while the commissioners of police continued to demand from that sum the ever-increasing product of a $4 d$. rate. Thus the government, in 1887-88, contributed to the police fund in respect of the London proportion of that fund $457,579 l$., and the county council has contributed in the six years under the Local Government Act an excess of $152,260 l$. beyond the last government contribution, as follows :-

\begin{tabular}{|c|c|}
\hline $1889-90$ & $\stackrel{£}{186}$ \\
\hline 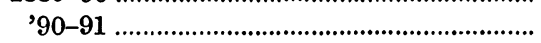 & 7,870 \\
\hline 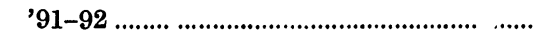 & 15,928 \\
\hline '92-93 & 24,421 \\
\hline 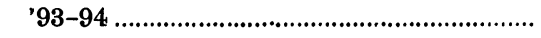 & 31,758 \\
\hline '94-95 & 33,197 \\
\hline & \\
\hline
\end{tabular}

3 By Section 22 (2) the particular cases of the Isle of Wight and South Wales main roads are met by a special addition to the discontinued grants for the purpose of the Local Goverument Board certificate. London therefore contributes proportionately to this special consideration of country roads at the same time as it suffers from the inadequacy of the grants for its own roads. The special additions amounted to 8,534l.- "Local Government Board Report, 1889-90," pp. xvi, 273 and 274. 
Whatever the total amount of the exchequer grant to the county may be, the amount falling to the police is an increasing amount, while that falling to the county council must in consequence be proportionately diminished. As between the council and the police therefore the new arrangement is not satisfactory.

But the new apportionment is not satisfactory as between the county of London and the rest of the country, and at this point the ratepayers of the county are directly interested. The proportion allotted to each county out of the exchequer contributions is based upon the total grants made in the year 1887. These grants included the police grant. In London this was four-ninths of the cost of the metropolitan police falling upon the rates, while in the country it was one-half the cost of pay and clothing. But the four-ninths taken as the London grant, was not four-ninths of the entire cost of the London police, because it did not include any grant in respect of the city of London police, nor was it four-ninths of the total cost of the metropolitan police, because a certain portion of the total cost was charged upon fees, licences, \&c., instead of upon rates. In these two respects therefore the comparison between London and the rest of the country cannot be expressed in the terms four-ninths of total cost and one-half of pay and clothing respectively.

The neglect of the consideration that the city did not participate in the government grant, has placed London at a disadvantage as compared with other counties by causing other counties to get more, because London in the past has paid a portion of its police which would otherwise have been paid by government. Before 1887 it was merely a question between the city of London and the imperial exchequer, but owing to the method of calculation imposed by the Act of 1888, it has become a question between the county of London and the rest of the country. There is no reason why other counties should benefit at the expense of London, but London should receive its proper proportion, let the distribution within London be what it may. In other words, the payment out of the city estates should act as a benefit to London, and not to other county areas, which divide amongst them the total sum derived from exchequer contributions. Had the government contributed to the city police in the same manner as to the metropolitan police, their contribution would have been fourninths of the cost, which, in 1887, would have amounted to 53,897 ., equal to a rate of $0^{\circ} 42 d$. in the $£$.

Turning next to the grant compared with total cost, the amount has to be considered in its relation to payments by London ratepayers for the police. These payments are not only rates, but also hackney carriage licences, fines, penalties, \&c. The 
total charge upon London for the metropolitan police (excluding the pension fund) is as follows:-

\begin{tabular}{|c|c|}
\hline 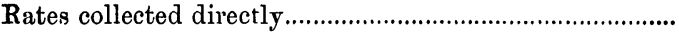 & $5 \cdot 00$ \\
\hline Exchequer contribution & 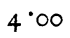 \\
\hline 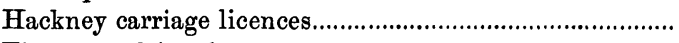 & 0.23 \\
\hline Fines, penalties, \&c. & 0.04 \\
\hline Showing the total cost to the ratepayers to be ......... & $9 \cdot 27$ \\
\hline
\end{tabular}

The comparison between London and the rest of the country, after taking into account these two considerations, shows that London gets $\frac{4}{0 \cdot 60}$ of the total cost as against the country's half cost of pay and clothing. It is difficult to compare these two figures with the limited information at hand, but, so far as it is possible to go, the comparison tells against London. Thus in 1887-88 the local taxation accounts give the total cost of police in boroughs as $940,3 \mathrm{r} 3 l$. of which $892,145 l$. was for pay and clothing, and towards which $386,266 l$. was paid in the year by the exchequer. Assuming that the full half cost of pay and clothing was paid in due course, the fraction $\frac{448,072}{940,818}$ represents $0^{\circ} 47$ of the entire cost of police to have been paid out of the exchequer grant in boroughs as against $0.4 \mathrm{I}$ (the equivalent of the fraction $\frac{4}{9 \cdot 69}$ quoted above) in London. This comparison too does not take into consideration the question of the extra total cost to London by reason of the imperial character of the metropolitan police force, nor of the cost of London police being increased by exceptional charges for police stations. If it is urged that the grant to London should have been limited to half the cost of pay and clothing of the entire London police, that is including the city, London's share in 1887 would have been $436,010 l$., instead of the present $457,579 l$; but this way of looking at the matter would leave the entire question of the cost of the imperial services of the metropolitan police to be dealt with as a matter between London and the government, and in the meantime it would open up a serious question for the consideration of the rest of the country in respect of the share obtained by London from the exchequer contribution account. If the amount of the grant over and above the half cost of pay and clothing is in part payment of the imperial duties of the police, it ought to be paid directly by the government, instead of from the funds set aside for distribution to the counties on an assumed equitable basis.

Upon this artificial basis, which it has taken so long to explain, the amount of imperial taxes now allocated to local taxation in London has been as follows:- 


\begin{tabular}{|c|c|c|c|c|}
\hline Year. & $\begin{array}{c}\text { Share of } \\
\text { Estate Duty. }\end{array}$ & $\begin{array}{l}\text { Share of } \\
\text { Beer and Spirit } \\
\text { Duties. }\end{array}$ & Total. & $\begin{array}{c}\text { Yearly Increase } \\
\text { or } \\
\text { Decrease. }\end{array}$ \\
\hline \multirow[t]{2}{*}{$\begin{array}{r}1889-90 . . . \ldots . \\
\text { '90-91........ } \\
\text { '91-92....... } \\
\text { '92-93........ } \\
\text { '93-94....... } \\
\text { '94-95....... } \\
\text { '95-96........ }\end{array}$} & $\begin{array}{c}£ \\
397,774 \\
423,995 \\
493,825 \\
421,248 \\
415,105 \\
358,538 \\
398,267\end{array}$ & $\begin{array}{c}£ \\
\ldots . \\
\text { I } 62,572 \\
\text { I } 79,134 \\
172,569 \\
172,759 \\
165,844 \\
178,558\end{array}$ & $\begin{array}{c}\mathfrak{£} \\
\mathbf{3 9 7 , 7 7 4} \\
\mathbf{5 8 6 , 5 6 7} \\
\mathbf{6 7 2 , 9 5 9} \\
\mathbf{5 9 3 , 8 1 7} \\
\mathbf{5 8 7 , 8 6 4} \\
\mathbf{5 2 4 , 3 8 2} \\
\mathbf{5 7 6 , 8 2 5}\end{array}$ & $\begin{array}{l} \\
\qquad \\
+\ldots \\
+\quad 26,221 \\
+\quad 86,392 \\
-\quad 79,142 \\
-\quad 5,953 \\
-\quad 63,482 \\
+\quad 52,443\end{array}$ \\
\hline & $2,908,752$ & $1,031,436$ & $3,940,188$ & $\ldots$ \\
\hline
\end{tabular}

This is $2 \mathbf{r}^{\circ} 96$ per cent. of the total amount devoted to the local taxation of England and Wales, and 17.57 per cent. of the total amount devoted to the local taxation of the United Kingdom. But before the amount is divided upon an artificial basis among the counties and county boroughs of England and Wales and the corresponding units of Scotland and Ireland, the total amount transferred from the imperial exchequer to local taxation is divided, again upon an artificial basis, between the three countries, the following being the proportions :-

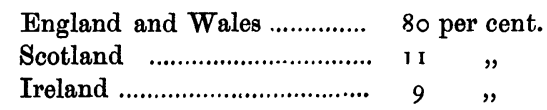

The amount allocated to each area therefore depends not only upon the correctness of the basis adopted for each locality, but also upon the correctness of the basis adopted for each of the three countries, and a more complex or artificial method of taxation can scarcely be conceived.

I hesitate to say what is the incidence of these taxes allocated to local taxation. Of course, because they are legally taken from the estate duty and the beer and spirit duties, it does not follow that they actually fall upon those duties. It can be argued with some force that they fall upon imperial taxation generally and not upon any one class of tax. But there is much, in my opinion, to show that this is not quite the fact. Imperial taxation consists of two classes, the permanent class and the shifting class. By the permanent class I mean taxes which are imposed, not with regard to the expenditure they have to meet, but with regard to the interests they tax. They would not be changed from year to year. By the shifting class I mean taxes which are readily changed from year to year as necessity arises. Thus the licences, estate duty, and beer and spirit duties are not fixed in reference to the calls upon them for grants to local taxation, but in reference to the principles governing those classes of taxation. They are fixed, 
not to meet the expenditure on particular services, but according to the expediency of imposing certain particular taxes. It follows from this that any increase in grants from imperial funds to local taxation would fall, not upon the taxes on which they are nominally charged, but upon the taxes which can be increased or decreased according to necessity, in other words, upon the shifting elements of taxation and not upon the permanent elements. The shifting elements, if I may so express myself, of the existing system of taxation are:-

(1) The income tax.

(2) Such of the customs and excise duties as can be altered having regard to their regulative character.

Customs and excise duties are now rarely increased, the tendency being to decrease them (see Parliamentary Return, Customs Tariffs of the United Kingdom, 1800-97). It may be noted in confirmation of this that the Chancellor of the Exchequer, in his present badget, proposes to reduce the duty on tobacco. The duty on tea, coffee, and cocoa also is often suggested as one which should be remitted at the earliest opportunity.

I think, therefore, that these grants allocated from imperial taxation to local taxation fall really upon the income tax and upon those custom duties which are ready for abolition or reduction; and $I$ think this incidence is most unjust and contrary to all principles of local taxation.

I have nothing to say about the police pension grant. It is a grant, and that is all that can be said of it.

There is next the education grant. This is made out of the consolidated fund, and no special taxation is created for it. Moreover, education is to all intents and purposes an imperial service. It therefore falls upon the several classes of imperial taxation proportionately, just as all national services would fall. With the assistance of Sir Alfred Milner's tables, "Royal Commission on "Agriculture," vol. iv, pp. 582 and 583, the following results have been obtained, to show the incidence of imperial taxation :-

\begin{tabular}{|c|c|c|c|c|}
\hline Classes of Taxation. & $\begin{array}{l}\text { Land and } \\
\text { other } \\
\text { Rateable } \\
\text { Property. }\end{array}$ & $\begin{array}{c}\text { Ton-Rateable } \\
\text { Property. }\end{array}$ & $\begin{array}{l}\text { Incomes } \\
\text { from } \\
\text { Personal } \\
\text { Earnings. }\end{array}$ & Consumers. \\
\hline 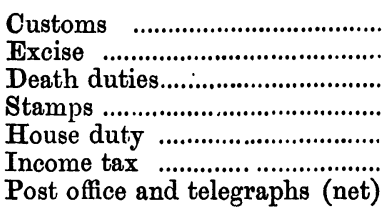 & $\begin{array}{c}\overline{-} \\
\overline{3,301,612} \\
1,425,371 \\
1,462,373 \\
5,598,570 \\
-\end{array}$ & $\begin{array}{l}\text { - } \\
5,452,732 \\
1,578,828 \\
- \\
5,379,846\end{array}$ & $\begin{array}{c}\bar{z} \\
\overline{-} \\
\overline{4,670,946}\end{array}$ & $\begin{array}{l}20,138,948 \\
25,875,626 \\
2,829,1142 \\
- \\
3,077,000\end{array}$ \\
\hline Percentage & $\begin{array}{r}11,787,926 \\
14 \% 59\end{array}$ & $\begin{array}{r}\text { I } 2,4 \text { I I, } 406 \\
\text { I5.36 }\end{array}$ & $\begin{array}{r}4,670,946 \\
5 \% 99\end{array}$ & $\begin{array}{r}5 \mathrm{I}, 920,7 \mathrm{I} 6 \\
64^{*} 26\end{array}$ \\
\hline
\end{tabular}


This excludes land tax and revenue which is not taxation. The former is excluded because it is a fixed amount, not affected by the education grant one way or the other, and having its origin many years before the cost of education was thrown upon the exchequer. The latter is excluded because it relieves the permanent crown services, and would not affect the education grant.

Of the total grant received by London for education in the year under review (1895-96) therefore the following are the amounts received from each class of taxation :-

\begin{tabular}{|c|c|c|c|c|c|}
\hline \multirow{4}{*}{ 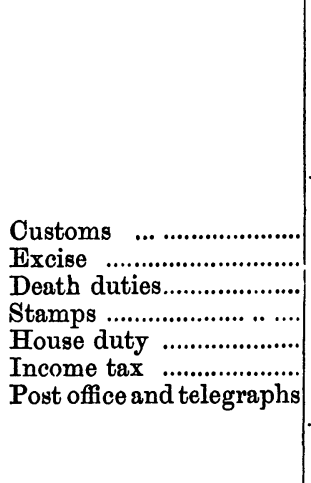 } & \multirow[b]{2}{*}{$\begin{array}{l}\text { Amount } \\
\text { of } \\
\text { the Tax. }\end{array}$} & \multicolumn{4}{|c|}{ Incidence of the Tax. } \\
\hline & & $\begin{array}{l}\text { Land and } \\
\text { other } \\
\text { Rateable } \\
\text { Property. }\end{array}$ & $\begin{array}{c}\text { Non- } \\
\text { Rateable } \\
\text { Property. }\end{array}$ & Incomes. & $\begin{array}{c}\text { Con- } \\
\text { sumers. }\end{array}$ \\
\hline & $\begin{array}{r}162,083 \\
208,253 \\
70,457 \\
46,948 \\
11,770 \\
125,949 \\
24,764\end{array}$ & $\begin{array}{l}\overline{-} \\
26,572 \\
11,472 \\
11,770 \\
45,059 \\
-\end{array}$ & $\begin{array}{l}\overline{-} \\
43,885 \\
12,707 \\
\overline{43,298} \\
-\end{array}$ & $\begin{array}{l}\bar{z} \\
\bar{E} \\
\overline{37,592}\end{array}$ & $\begin{array}{c}162,083 \\
208,253 \\
- \\
22,769 \\
= \\
24,764\end{array}$ \\
\hline & 650,224 & 94,873 & 99,890 & 37,592 & 4 '7,869 \\
\hline
\end{tabular}

I next come to the Diseases of Animals Act, 1894. Under that Act if in any financial year the money standing to the cattle pleuro-pneumonia account for Great Britain is insufficient to defray the costs and expenses under that Act, the Local Government Board may deduct from the local taxation account and pay into the cattle pleuro-pneamonia account such sums as may be certified by the Board of Agriculture to be required; so that, having allocated a certain amount of imperial taxation for local taxation purposes, it is dipped into for imperial purposes. The process is, to say the least of it, bewildering. The "money stand"ing to the pleuro-pneumonia account" consists of the amount voted by Parliament from year to year and the amounts recovered by the sale of carcases.

The following table shows the expenditure out of the cattle pleuro-pneumonia account for Great Britain, and the manner in which it has been met.for the last five years for which the figures are published.

From this table it will be seen that prior to the year 1894-95 the expenditure out of this account was borne by the imperial exchequer. Since that date (i.e., after the passing of the Diseases of Animals Act, 1894) the bulk of the expenditure has been 
defrayed out of amounts deducted from the local taxation account under the powers mentioned above, and the contributions to local authorities out of that account have been correspondingly reduced.

\begin{tabular}{|c|c|c|c|c|c|}
\hline & $1891-92$. & $1892-93$ & 1893-94. & 1894-95. & $1895-96$ \\
\hline Expenditure- & $£$ & $£$ & $£$ & $£$ & $£$ \\
\hline $\begin{array}{c}\text { Salaries and travelling ex }- \\
\text { penses }\end{array}$ & 15,089 & 9,494 & 19,346 & 60,908 & 67,109 \\
\hline 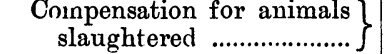 & 145,843 & 42,512 & 52,467 & 115,070 & 120,350 \\
\hline Miscellaneous expenses ......... & 9,532 & 3,795 & 9,574 & 29,114 & 29,305 \\
\hline Total ......................... & 170,464 & 55,801 & 81,387 & 205,092 & 216,764 \\
\hline $\begin{array}{l}\text { Receipts in aid- } \\
\text { Salvage on carcases.................. }\end{array}$ & 57,396 & 16,840 & 20,350 & $30,4,20$ & 27,223 \\
\hline Expenditure falling on taxation & 113,068 & 38,961 & 61,037 & 174,672 & 189,541 \\
\hline $\begin{array}{l}\text { Imperial taxation-Vote } \\
\text { Local taxation-... }\end{array}$ & $18 \AA, 000$ & 50,000 & 15,000 & 35,000 & 25,000 \\
\hline 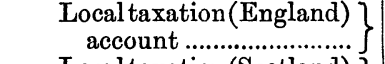 & $\cdots$ & $\cdots$ & $\cdots$ & 79,200 & 145,200 \\
\hline $\left.\begin{array}{r}\text { Local taxation(Scotland) } \\
\text { account }\end{array}\right\}$ & $\cdots$ & $\cdots$ & $\cdots$ & 10,800 & 19,800 \\
\hline Balance increased or decreased & $+71,932$ & $+11,039$ & $-46,037$ & $-49,672$ & $+\quad 459$ \\
\hline
\end{tabular}

The amounts withdrawn from the local taxation (England) account have been as follows:-

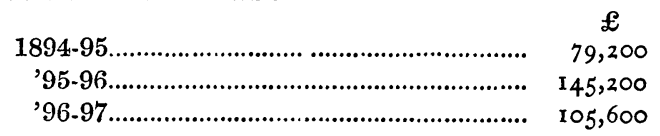

These amounts are deducted from the estate duty grant, which is apportioned among the counties and county boroughs on the basis of the old grants, and the amounts thereby deducted from the grant receivable by London are as follows :-

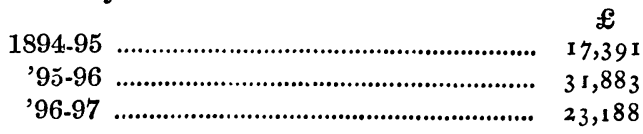

The bulk of the expenditure out of the pleuro-pneumonia account is now for swine fever, and there can be no doubt that the cost to London would be far less if the expenditure was met locally. It is not of course possible to ascertain exactly what would be the cost to London of dealing with swine fever, but the number of animals may be taken as some indication of London's proportion of the cost. In 1896, according to the Board of Agriculture returns, the number of swine in London was only $0^{\circ} \mathrm{I}$ per cent. of the number in England and Wales, while London contributes to the cost of swine fever through the local taxation account at a proportion of 22 per cent. of the whole country.

VOL. LXI. PART III. 
With reference to the grants under the Agricultural Rates Act, the analysis of the recent government return is as follows :-

\begin{tabular}{|c|c|c|}
\hline \multirow{5}{*}{ 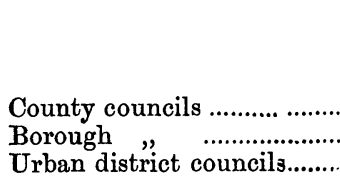 } & London. & Rest of the Country. \\
\hline & $£ \quad s . \quad d$. & $\begin{array}{lll}£ & s . & d .\end{array}$ \\
\hline & $931 \quad 10 \quad 2$ & 328,267 II 6 \\
\hline & - & $18,12 \mathrm{I} \quad 3 \quad 4$ \\
\hline & - & $5,366 \quad 5 \quad 8$ \\
\hline Rural $\quad, \quad, \quad \ldots \ldots .$. & - & $327,091 \quad 310$ \\
\hline 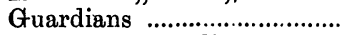 & $1,214 \quad 16$ & $504,844 \quad 10 \quad 5$ \\
\hline Metropolitan police ............. & 3225 & $4,067 \quad 9 \quad 6$ \\
\hline 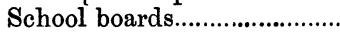 & $70510-$ & $106,64 \mathrm{I} \quad \mathrm{3} \quad 8$ \\
\hline Highway boards......................... & - & $16,368 \quad 7$ \\
\hline Surveyors of highways......... & - & 18,570 \\
\hline & $3,174 \quad 1 \quad 11$ & $1,329,338$ \\
\hline
\end{tabular}

This amount, 3 I $74 l$. Is. I $d$., being paid for out of the consolidated fund, that is, it is paid for not out of increased taxation specially raised to meet it, but out of general taxation, is practically divided among the several classes of imperial taxation in much the same way as the education grants.

This Act introduces the system of paying a proportion of rates levied. It is limited to rates upon one particular class of property -a class not favourable to London and other urban districts, namely, agricultural land; and it raises more than any other class of appropriation of imperial taxation, the issue as to whether the recipient areas get back proper proportions of taxation which they pay to the State. I know of no Act of Parliament which has so violently disturbed every principle of local taxation.

Like almost everything else in matters of public concern in this country, the present complications between imperial and local taxation have been the growth of some years-a growth which has been allowed to proceed without adequate, or indeed any consideration as to results.

The practice of making grants from the imperial funds in aid of local taxation was commenced in 1833 , by a grant towards the cost of the metropolitan police, and it has been extended from time to time by grants towards the following services:-

1835. Criminal prosecutions.

'46. Teachers in poor law schools and poor law medical officers.

'56. Police (counties and boroughs).

1865-66. Metropolitan Fire Brigade.

1870. Education.

1873-74. Medical officers and sanitary inspectors.

1874. Pauper lunatics.

75. Registration of births and deaths.

'76. Industrial schools.

'82. Disturnpiked and main roads.

'91. Education-fee grant. 
Up to 1888 these grants were made direct to the authorities who spent the money, and were a fixed proportion of the amount spent, being subject to a check by the imperial authority by means of a proper system of audit and by provisions for disallowances. The very important departure in 1888 made in the method of fixing the amount of all these grants, except those for education and the fire brigade, is thus shown to be not only a matter of amount but of principle, and one which has very important bearings upon the relationship of local taxation to imperial taxation and upon the operation of local taxation. This departure has been followed up, as I have shown, by other innovations in 1894 and in 1896, and I think it has become almost hopeless to understand what local taxation now is.

The relationship of imperial to local taxation is one of great moment in the interests of the taxpayer. Changes are made by parliament in imperial taxation without any reference to how it may affect interests already touched by local taxation, and there is no corresponding power in local authorities to change the incidence of local taxation so as to rectify any injustice. This matter is becoming more and more of importance now that local government is called upon to do so much more in the interests of the people of each particular area, and I would refer to Professor Bastable's valuable work on "Public Finance" for the scientific exposition of this proposition.

There is further to observe that the artificial splitting up of taxes collected from individuals in all parts of the country, and not governed by local incidence, is beneficial neither to imperial nor to local finance. It depletes the national treasury of a sum which belongs by the incidence of the tax to the national area and not to local areas; it adds to the local treasuries sums which belong to the national area. The national tax so appropriated and the local taxation so relieved cannot be properly understood by the taxpayers in the same manner as a tax collected and applied within the area of its incidence, for it adds to the natural perplexities of taxation the perplexities of artificial arrangements. The taxpayer not being an expert cannot find out for himself how these matters work, either with reference to the imperial government or to the local government, and there are no statistics to help him. Moreover, this kind of taxation places local authorities in proportionate fiscal dependence upon the imperial government, which is not conducive to economy, while the fluctuations of increase or decrease from year to year, which in relation to the imperial exchequer do not cause any great dislocation of taxation from year to year, cause very considerable dislocation in local taxation. Thus the windfall in the year 1891-92 could not be made of effective use because of the 
considerable proportion which it bears to total local taxation, and the uncertainty as to the amount which might normally be considered as proper to be set aside as relief to rates from imperial exchequer. On the other hand a serious drop, as in 1893-94, would send the rates up to a high figure, and cause a zigzag fluctuation in rates which is serious to many ratepayers.

I next come to the indirect local taxation. This consists of several items, of which the following are the distinguising kinds :-

1. Licences, duties, \&c., collected in the area of the county by the Inland Revenue Commissioners, and handed over to the London County Council..

2. Tax upon fire insurance companies at $35 l$. per million of insurance effected in the county of London, collected by and applied by the London County Council

3. Licences for petroleum, explosives, cowhouses, slaughter houses, locomotives, theatres, and sky-signs, fees in respect of dangerous structures and Building Act, collected by and applied by the London County Council

4. Licences for explosives and sky-signs, collected and applied by the City Commissioners of Sewers (dangerous structures are not separately stated, and cannot therefore be given)

5. Licences for petroleum and locomotives, collected and? applied by the City of London Corporation .................. $\}$

6. Fees payable for stamping weights and measures, collected and applied by the London County Council........ $\}$

7. The same, collected and applied by the City Commis-? sioners of Sewers.....

8. Licences for public carriages, collected and applied by the Metropolitan police

9. Fees payable for certificates to pedlars and chimney sweeps, collected and applied by the Metropolitan police

10. Licences for advertisement hoardings, collected and applied by vestries and district boards and by the City Commissioners of Sewers

11. Market dues and tolls, collected and applied by the City of London Corporation

12. The same, collected and applied by the Woolwich Local Board, and the market trustees of Whitechapel and St. Saviour

13. Grain duty and fruit metage, collected and applied by the City of London Corporation

14. Fees from canal boats, collected and applied by the City of London Corporation

15. Burial fees, collected and applied by the vestries, burial boards, and City Commissioners of Sewers

16. Fees received from the City of London Court over and above the cost of maintaining the court and of salaries of judges and staff, collected and applied by the City of London Corporation

An important point to note in connection with this indirect taxation is that the area of taxation is not in all cases coincident 
with the area of administration. Thus the Metropolitan police levy and receive the licence fees for hackney carriages in the city of London, though they have no police jurisdiction within the city; and although the levy extends throughout the entire area of greater London, it is nearly certain that the greater part of the amount is levied within the city and county of London, the result being an injustice to London, namely, that London taxation is not wholly applied to London matters. Secondly, there is the indirect taxation by way of grain duty and market tolls levied and applied by the City of London Corporation. The area of this taxation is far beyond the city boundary, to some extent beyond the county boundary. In respect of the grain duty, the City Corporation are bound by Act of Parliament to apply it to open spaces outside the area of the county, but presumably for the benefit of Londoners primarily, although the anomaly is not quite explained by the benefit which Londoners are supposed to receive from Epping Forest, Burnham Beeches, West Wickham Common, and other places. In respect of market tolls and dues the corporation apply the taxation derived from the county to purposes belonging to the city. This fact is of some importance, considering the frequent complaints of the city that they pay too much towards equalising the rates of the rest of London. Thirdly, there are the market dues and tolls levied by the local markets of Southwark, Whitechapel, and Woolwich. These taxes are paid by the consumers of an area much larger than the parishes, though they are applied to the benefit of the parishes only. These are anomalies which generally are not considered in connection with London taxation, but they are nevertheless of some importance when London taxation is being scientifically examined.

Finally, I come to direct local taxation. This amounted, as I have already stated, to 9:904,675l., and is imposed by five different classes of authorities, namely, county authorities, district authorities, union authorities, special district authorities, and parish anthorities. All authorities, except parish authorities, levy their rates by means of precepts sent down to the parish, the unit of valuation in all cases being the parish. The parish has to add the amount of the demands by precept to the amount of the parish rates, and to collect the whole sum from the ratepayers through one or other of the parish rates. The rates in London are poor rate, general rate, sewers rate, lighting rate, church rate, consolidated rate, and ward rate. The technical names of these rates, which are derived from a condition of things no longer existing, do not cover the items included under each rate. Thus, the poor rate includes the county rate, the police rate, the contributions assessed by the asylums board, the sick asylums managers, and 
the school district managers, the overseers' charges, the library rate, the contributions assessed by the burial boards, together with the charges of the guardians for poor law purposes proper. The general rate includes the school board rate, the contributions assessed by the district boards, together with the charges of the vestries for general purposes under the Metropolis Management Act, 1855. The sewers rate includes the contributions assessed by the district boards and the charges by the vestries in respect of sewers under the Metropolis Management Act, 1855. The lighting rate includes the contributions assessed by the district boards and the vestry charge for lighting under the Metropolis Management Act, 1855. The consolidated rate is the rate levied by the City Commissioners of Sewers for all its purposes' except sewers, for which a separate rate is levied; the ward rate is the rate levied by the City of London Corporation for ward purposes ; and the church rate is levied by the churchwardens and overseers in certain parishes for church purposes. There is the trophy or militia rate periodically levied by the Commission of Lieutenancy of the City of London.

The unit of levy by all precept authorities is the parish, according to the valuation prepared under the Valuation Metropolis Act, 1869, and the County Rates Act, 1852. The unit of levy of the parish authority is each individual hereditament entered in the parish valuation list, and it thus happens that the rates of the precept authorities reach the ratepayer not directly from each authority but indirectly through the parish.

Thus the parish bears county, district, union and parish taxation. It bears county taxation in that the levies by all the county authorities are made rateably upon the parish valuation, and are then transferred by the parish authorities to the taxpayers; it bears district and union taxation (whenever it occurs) in that levies by district boards and poor law unions are made rateably upon the parish valuation, and then transferred by the parish authorities to the taxpayers; it bears parish taxation directly through the parish authorities.

County taxation falls equally upon the rateable value of the parts of London which bear it; upon county taxation is superimposed the district and union taxation in those parts of London which bear this class of taxation; and then finally, in some parts of London, upon county taxation, district taxation, and union taxation, parish taxation is superimposed; in other parts upon anion taxation and county taxation parish taxation is superimposed, while in other parts of London parish taxation is superimposed directly upon county taxation.

The fact that in all cases, except the city of London consoli- 
dated rate, ward rate, and police rate, the ancient parish is the rating unit, brings into prominence the importance of the present relative positions of the several parishes. The area, population, valuation, and administrative importance of the parishes differ very considerably. There are in all 192 parishes in the administrative county of London, of which 30 are governed by administrative vestries for all local municipal matters, 42 have vestries with no administrative powers, $I_{12}$ are parishes in the city of London whose civil powers are now of no importance, and 8 are places in Schedule $\mathrm{C}$ of the Metropolis Management Act. To show how unequally these parishes divide between them the area of the county of London, the following particulars as to the largest and smallest parish in each class are given :-

\begin{tabular}{|c|c|c|c|c|c|}
\hline \multirow[b]{2}{*}{ Administrative parishes ......... } & \multirow[b]{2}{*}{ Largest .... } & Name of Parish. & $\begin{array}{l}\text { Area in } \\
\text { Acres. }\end{array}$ & $\begin{array}{c}\text { Population, } \\
1896 .\end{array}$ & $\begin{array}{c}\text { Rateable } \\
\text { Value, } 1896 .\end{array}$ \\
\hline & & 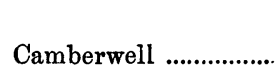 & \multirow{2}{*}{$\begin{array}{r}4,450 \\
163\end{array}$} & 253,076 & $\begin{array}{c}£ \\
1,143,248\end{array}$ \\
\hline \multirow{3}{*}{ Non-administrative parishes } & Smallest & 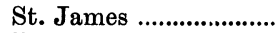 & & 23,050 & 801,105 \\
\hline & Largest .... & 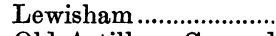 & \multirow{2}{*}{$\begin{array}{r}5,773 \\
5\end{array}$} & 83,213 & 539,527 \\
\hline & Smallest & Old Artillery Ground & & 2,143 & 8,613 \\
\hline \multirow{2}{*}{ Parishes in the city of London } & Largest .... & $\begin{array}{l}\text { St. Botolph, Bishops- } \\
\text { gate }\end{array}$ & 44 & $\mathbf{1 , 7 4 4}$ & 186,570 \\
\hline & Smallest & 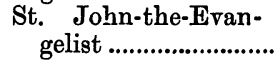 & \} & 17 & 9,511 \\
\hline
\end{tabular}

The separation of the ultimate rating unit into these small and varied areas must necessarily cause a differentiation of rating for which there is no adequate compensation.

Before however considering how this amount of expenditure of I $1,834,390 l$. actually falls as taxation in London, it is necessary to point out two facts. The first is peculiar to London, namely, that there is considerable difference between the expenditure incurred by the various authorities and the taxation imposed by these authorities. Secondly, there is the increase or decrease of balances which occurred during the year. If a balance is increased, it is increased at the expense of the ratepayers of the year, while if a balance is decreased, the local authority has met part of the year's expenditure out of accumulated balances of past years. In both ways therefore balances affect the amount of expenditure which is finally borne by taxation. The following table shows the facts for 1895-96:- 
[Sept.

\begin{tabular}{|c|c|c|c|c|}
\hline \multirow[b]{2}{*}{ Authorities. } & \multirow[b]{2}{*}{$\begin{array}{l}\text { Expenditure } \\
\text { Incurred. }\end{array}$} & \multicolumn{2}{|c|}{ Balauces. } & \multirow{2}{*}{$\begin{array}{l}\text { Net Charge } \\
\text { on } \\
\text { Taxation } \\
\text { after } \\
\text { Accounting for } \\
\text { Balances. }\end{array}$} \\
\hline & & $\begin{array}{c}\text { Increased } \\
\text { and } \\
\text { added to } \\
\text { Expenditure. }\end{array}$ & $\begin{array}{c}\text { Decreased } \\
\text { and } \\
\text { deducted } \\
\text { from } \\
\text { Expenditure. }\end{array}$ & \\
\hline 1 County Authorities- & $£$ & $£$ & $£$ & $£$ \\
\hline London County Council .......... & $2,042,169$ & 117,802 & - & $2,159,971$ \\
\hline School Board for London.......... & $2,330,432$ & - & 48,596 & $2,281,836$ \\
\hline Metropolitan Asylums Board & $44^{8}, 4^{6} 5$ & - & 29,900 & $4: 18,565$ \\
\hline$" \quad$ police & $1,273,717$ & - & 3,483 & $1,270,234$ \\
\hline \multicolumn{5}{|l|}{ 2. District Authorities- } \\
\hline City of London Corporation .. & 257,971 & - & 44,395 & 213,576 \\
\hline „Commissioners of Sewers & 243,783 & 24,579 & - & 268,362 \\
\hline 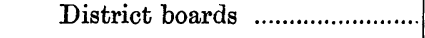 & $503,35^{8}$ & 24,148 & - & 527,506 \\
\hline Library commissioners ............... & 2,571 & - & 77 & 2,494 \\
\hline \multicolumn{5}{|l|}{ 3. Union Authorities- } \\
\hline Boards of guardians .................... & $I, 284,724$ & 51,184 & - & $1,335,908$ \\
\hline \multicolumn{5}{|l|}{ 4. Special District Authorities- } \\
\hline Sick asylum district managers & 32,473 & - & 1,388 & 31,085 \\
\hline School district managers ......... & 120,928 & 37 & - & 120,965 \\
\hline Library commissioners ............... & 2,496 & 162 & - & 2,658 \\
\hline Wards of the city & 6,931 & 34 & - & 6,965 \\
\hline \multicolumn{5}{|l|}{ 5. Parish Authorities- } \\
\hline Vestries and local board .......... & $1,785,640$ & - & $39, \approx 80$ & $1,746,360$ \\
\hline Boards of guardians .................... & $\mathrm{I}, 133,498$ & 34,081 & - & $1,167,579$ \\
\hline 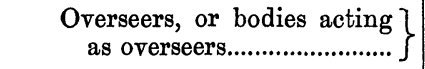 & 178,209 & 69,410 & - & $247,619^{\circ}$ \\
\hline Library commissioners .............. & 54,193 & - & 714 & 53,479 \\
\hline Baths " " & 71,330 & 6,693 & - & 78,023 \\
\hline 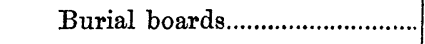 & 49,121 & 1,212 & - & 50,333 \\
\hline 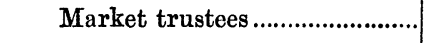 & 2,483 & - & 780 & 1,703 \\
\hline 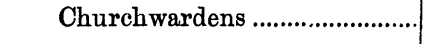 & 9,898 & 554 & - & 10,452 \\
\hline Totals ............................. & I I $, 834,390$ & 329,896 & 168,6 I 3 & $11,995,673$ \\
\hline
\end{tabular}

So that a total expenditure incurred of II $_{1}, 834,390 l$. becomes a total taxation of i $1,995,673 l$. 
Comparing this charge on taxation with the taxation imposed by the various authorities, the result is as follows :-

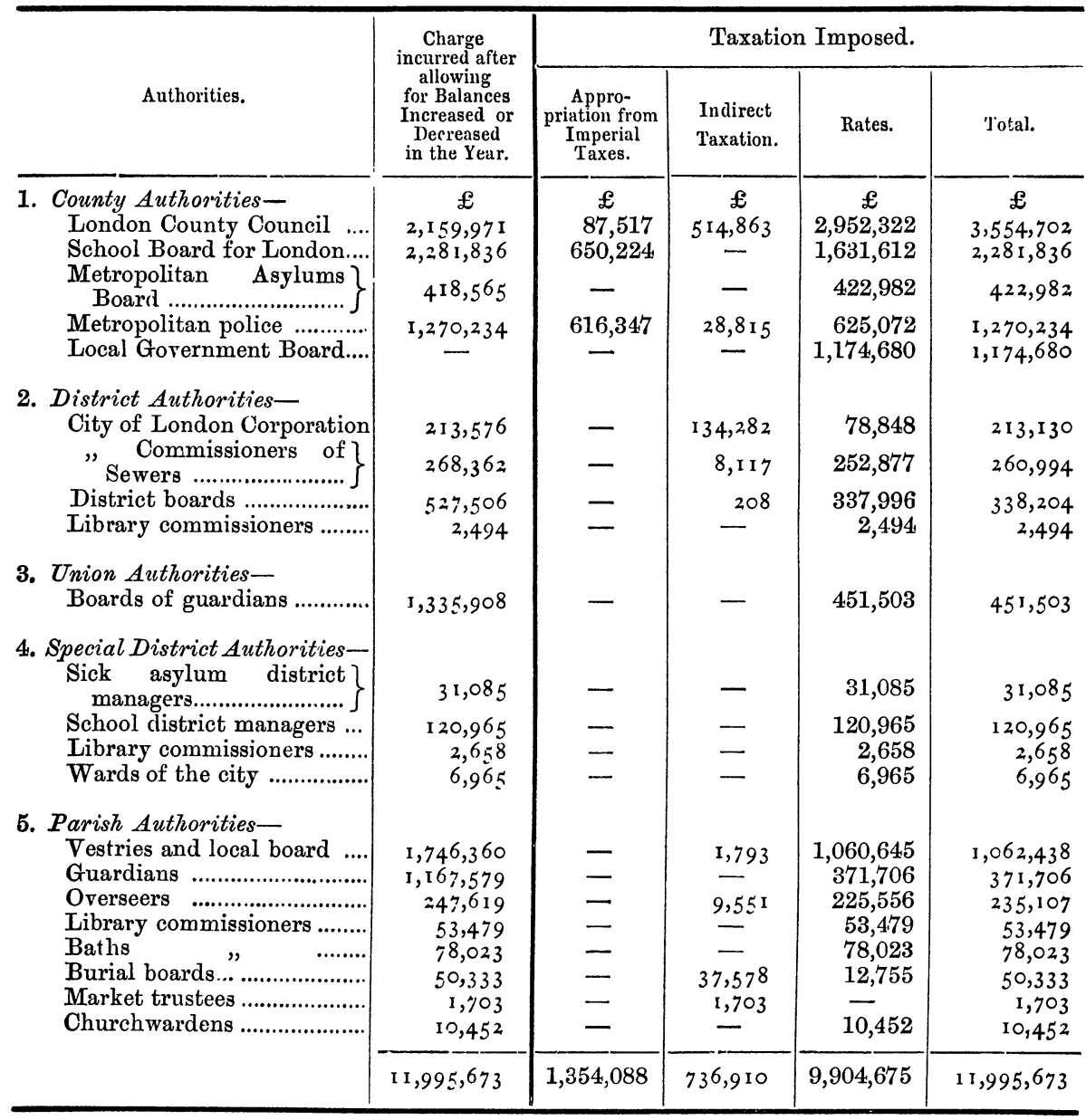

In the case of the County Council and the Asylums Board the taxation imposed is in excess of the expenditure incurred, while a wholly new authority, the Local Government Board, appears as a taxing authority without having incurred any expenditure. On the other hand, the city corporation, the Commissioners of Sewers, district boards, vestries, guardians and overseers impose less taxation than the expenditure they incur. But in the total the expenditure and taxation amount to the same sum ( $11,995,673 l$.).

These differences between expenditure incurred and taxation 
imposed by the different authorities are caused by the operation of certain equalisation funds, which have for their object the equalisation of the rates which fall upon the rating units. These funds are as follows :-

Common Poor Fund (Act of 1867, and amending Acts).

County Grants (Act of 1888).

Equalisation Fund (Act of 1894).

The common poor fund is administered by the Local Government Board. Certain charges in connection with the maintenance of in-door paupers and lunatics, and for registration and vaccination, incurred by the guardians of the poor of the several parishes and unions in the county, are transferred to this fund, and the amount required to meet them is raised by an equal rate over the metropolitan poor district, i.e., the administrative county, excluding Penge.

The county grants are administered by the London County Council. They consist of grants to guardians, sanitary authorities, and overseers, in aid of the following services :-

Guardians of the poor-

Pauper lunatics.

Poor law medical expenses.

Registrars of births and deaths.

Teachers in poor law schools.

In-door poor.

Sanitary authorities (vestries and district boards) -

Medical officers.

Sanitary inspectors.

Main roads.

Overseers-

Registration of electors.

Drowned bodies.

The rates to meet these grants are levied over the whole county, with the exception of that for drowned bodies, which is charged on the special county rate, and is therefore not levied on the city.

The Asylums Board also administers a small amount of grants. These are repayments to local authorities of fees paid for the notification of infectious diseases, under the Public Health Act, 1891. The rate to meet these grants is charged, along with the rest of the expenses of the Asylums Board, upon the Metropolitan Asylums District.

The equalisation fund is administered by the London County Council. It consists of a rate of $6 d$. in the $£$ levied annually on the whole county, and redistributed among, the sanitary authorities on the basis of population. 
The effect of these funds is to relieve parish, union, and district expenditure at the expense of county rates. The total transfer of charge thus made in 1895-96 was as follows :-

To the Common Poor Fund-

From guardians of unions

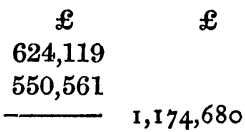

To the County Fund-

From guardians of unions

parishes

$$
1,174,680
$$

,

parishes

260,190

245,312

district boards

6,736

vestries

13,898

overseers

12,512

City of London Corporation

445

To the Asylums Board-

From vestries $(3,552 l$.$) , district boards$ $(842 l$.$) , city commissioners (22 l$.$) , and$ city corporation ( $\mathrm{I} l$. )

To the Equalisation Fund-

From district boards

" vestries

7,346

"guardians in respect of parishes in Schedule Cof the Metropolis Management Act, 1855

”

Overseers, ditto

Total amount of parish, union, and district

expenditure paid out of county rates

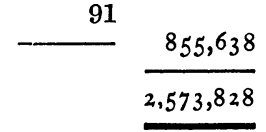

The expenditure of boards of guardians transferred to the common poor fund was as follows :-

\begin{tabular}{|c|c|}
\hline & $£$ \\
\hline \multirow{2}{*}{\multicolumn{2}{|c|}{$\begin{array}{c}\text { Maintenance of lunatics and irsane poor ........ } \\
\qquad, \quad \text { fever and small pox patients }\end{array}$}} \\
\hline & \\
\hline Medicine and medical appliances ......................... & 15,438 \\
\hline 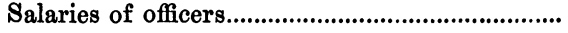 & 250,817 \\
\hline 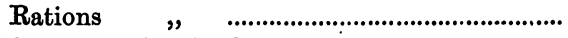 & 82,667 \\
\hline Compensation for loss of office, \&c. ..................... & $\mathbf{1}, 595$ \\
\hline Registration fees & I 1,078 \\
\hline Vaccination fees and expenses & I3,093 \\
\hline 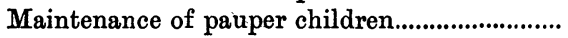 & 182,856 \\
\hline 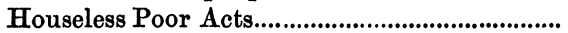 & 22,301 \\
\hline Maintenance of in-door pa & 282,070 \\
\hline children .............. & \\
\hline 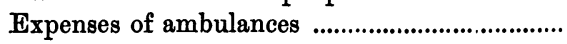 & 17,372 \\
\hline & 174,680 \\
\hline
\end{tabular}

Before dismissing this important subject of equalisation, it should be pointed out how cumbersome is the machinery at 
present adopted. The systiem has been allowed to grow without reference to the effect of each succeeding growth upon the preceding part. At the time of the institition of the common poor fund in 1867 there was no county authority and no other equalisation fund. Now there is a county authority, and two other equalisation funds administered by that authority. The overlapping of jurisdictions is not conducive to administrative efficiency. Take for instance the case of lunacy. The whole charge for pauper lunatics is now a county charge, but it becomes so in the following tortuous manner. First, there is the county lunacy administered by the county asylums committee and paid for by the county rate. Secondly, there is the local lunacy administered by the thirty boards of guardians, but paid for partly by the common county charge of the Metropolitan Asylums Board, partly by the grant from the county fund of $4 s$. per head per week, and partly by the common poor fund. All this machinery to produce so simple a result as a common county charge for London lunacy must be productive of unnecessary expense, if not inefficient administration, and at all events the London County Council employs a staff to examine the guardians' lunacy accounts for the purpose of determining the amount of the grants, which are also examined by the Local Government Board for the purpose of determining the amount to be paid by the common poor fund. Now that the council is charged with the duty of disbursing certain county grants, and with the duty of administering the equalisation fund, it should also be charged with the administration of the common poor fund, subject to some simplification of method. Payments out of the fund could be made on the certificate of the Local Government Board as at present, so that no change would be made in the machinery of control, but only in the machinery of administration. Further, the grants out of the county fund to local authorities should be made clear of the county rate proper and constituted a part of the equalisation fund.

The area with which each item of the charge on rates is shared, that is, the area among the parishes of which the charge on rates is apportioned on the basis of rateable value, forms an important feature of taxation by direct charge on rateable value. The largest area with which rates are shared is the Metropolitan police district, with which the police rate is shared. All other rates are shared either with the county, with an area somewhat less than the county for special purposes, with a specially constituted district for poor law schools or for sick asylums, with a sanitary district or poor law union, or with the parish.

The areas which consist of groups of parishes are as follows :- 
Area with which Rates are Shared.

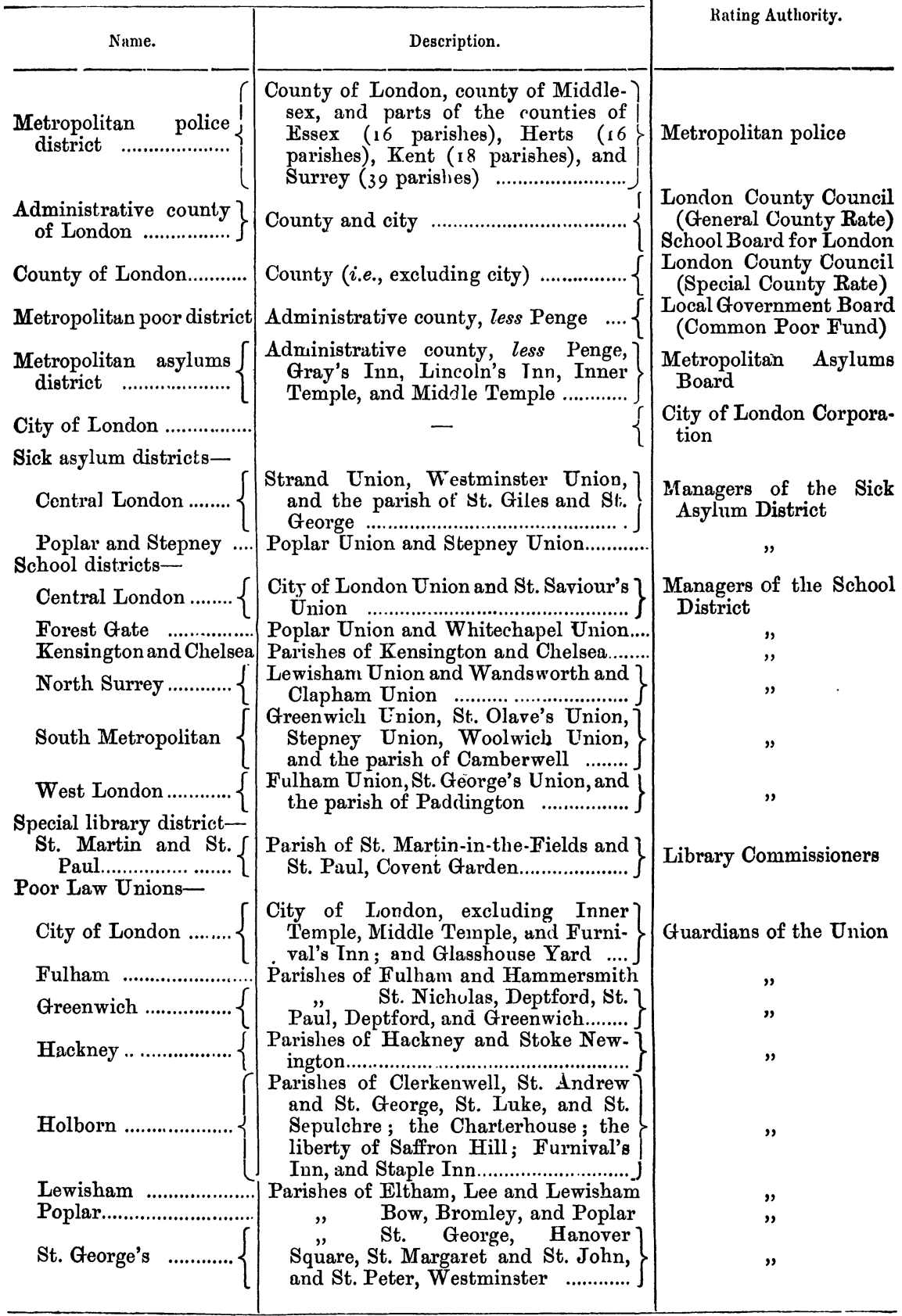




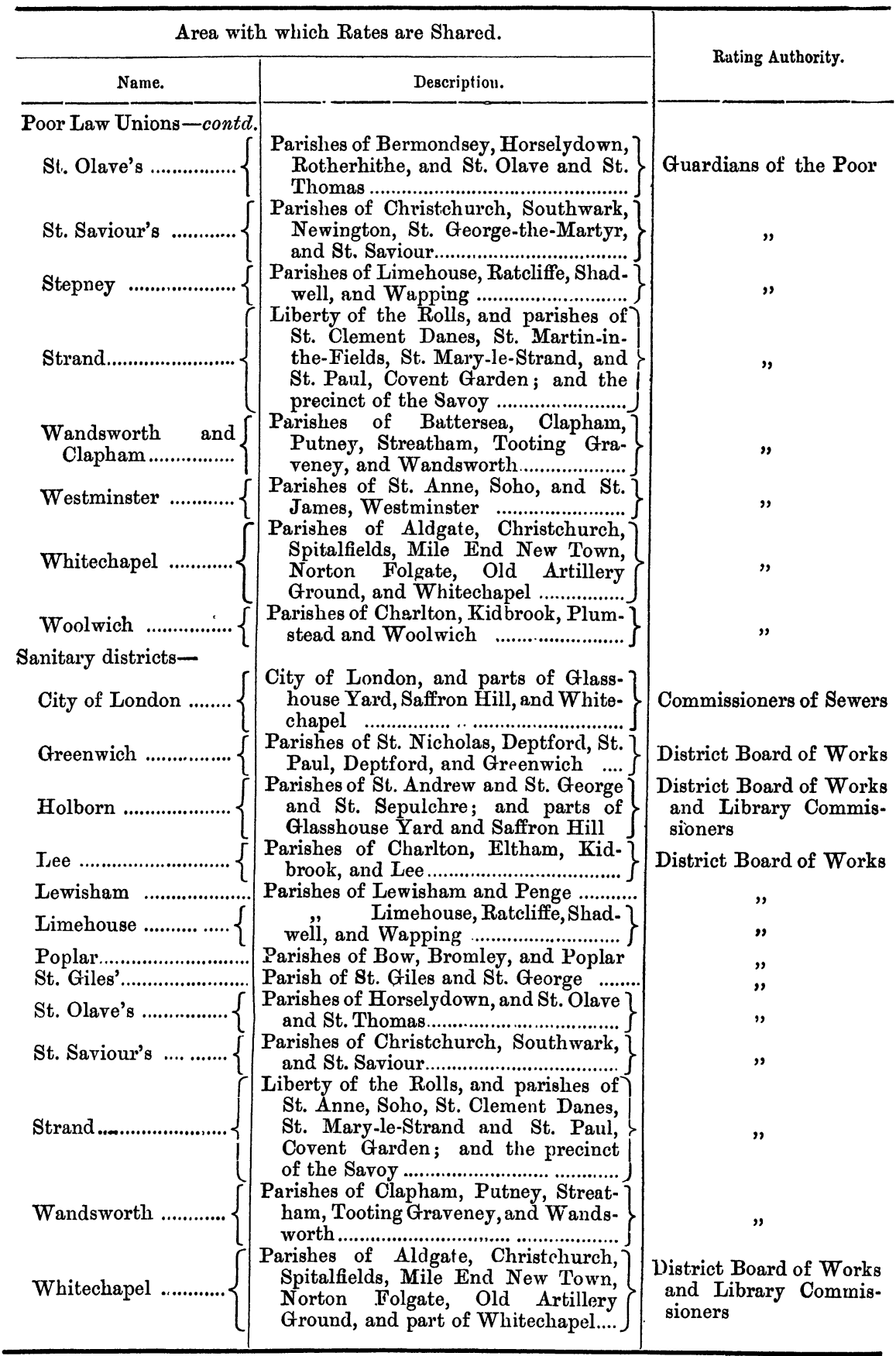


As regards the remaining authorities the charge falling on rates is shared with the parish area. These authorities are :-

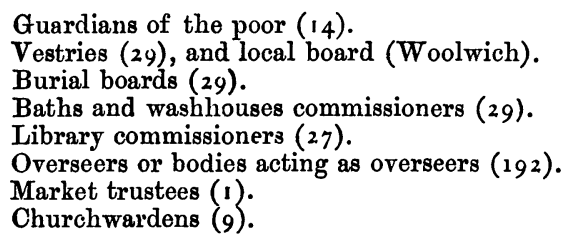

In the case of district boards and guardians of unions, however, the whole of the charges are not technically "shared" by the constituent parishes; that is to say, the whole of the charges are not apportioned among the parishes upon the basis of rateable value. In the accounts of some of these authorities there are certain items of expenditure which are charged to the individual parishes in respect of which they are incurred, and in a few cases there are items of receipt credited to individual parishes. In two particular cases, viz., Wandsworth District Board and Lee District Board, none of the charges appear to be apportioned rateably between the parishes, the whole of the expenditure being charged according to works in the several parishes. In the case of Greenwich and Lewisham District Boards also the greater part of the expenditure is charged separately to the parishes.

Although the charges of the central authorities and most of the district authorities are apportioned rateably among the constituent parishes, this apportionment is not always upon the statutory rateable value in force for the year, and thus certain parishes gain at the expense of others. The most notable instance of this is the contribution of Woolwich to the common poor fund, which works out at only $2 l$. $19 s .5 d$., instead of $3 l .9 s$. $1 d$., the parishes in the union thus escaping a rate of $9 s .8 d$. Another instance is the contribution of Tooting to the school board, which works out at only $4 l$. 1Os. $9 d$., instead of $4 l .15 s .4 d$., a gain of $4 s .7 d$. St. Sepulchre again paid only $4 l$. $13 s .5 d$. to the school board, instead of $4 l .15 s .4 d$., and $3 l .2 s .6 d$. to the guardians, instead of $3 l .5 s .8 d$., a total exemption of 5 s. I d.

This question of the area with which direct taxation is shared is thus a very important one; so important indeed, that it may create a heavy or light charge according to the position of the property which has to bear the taxation. It leads to serious differentiation of rates as between the different rating areas, the parishes.

Before considering differentiation of rates, it will be well to ascertain what has been done towards obviating the most serious inequalities of direct taxation in London. I have already described the process and given the figures in gross for all London. The following table shows the facts for each parish. 


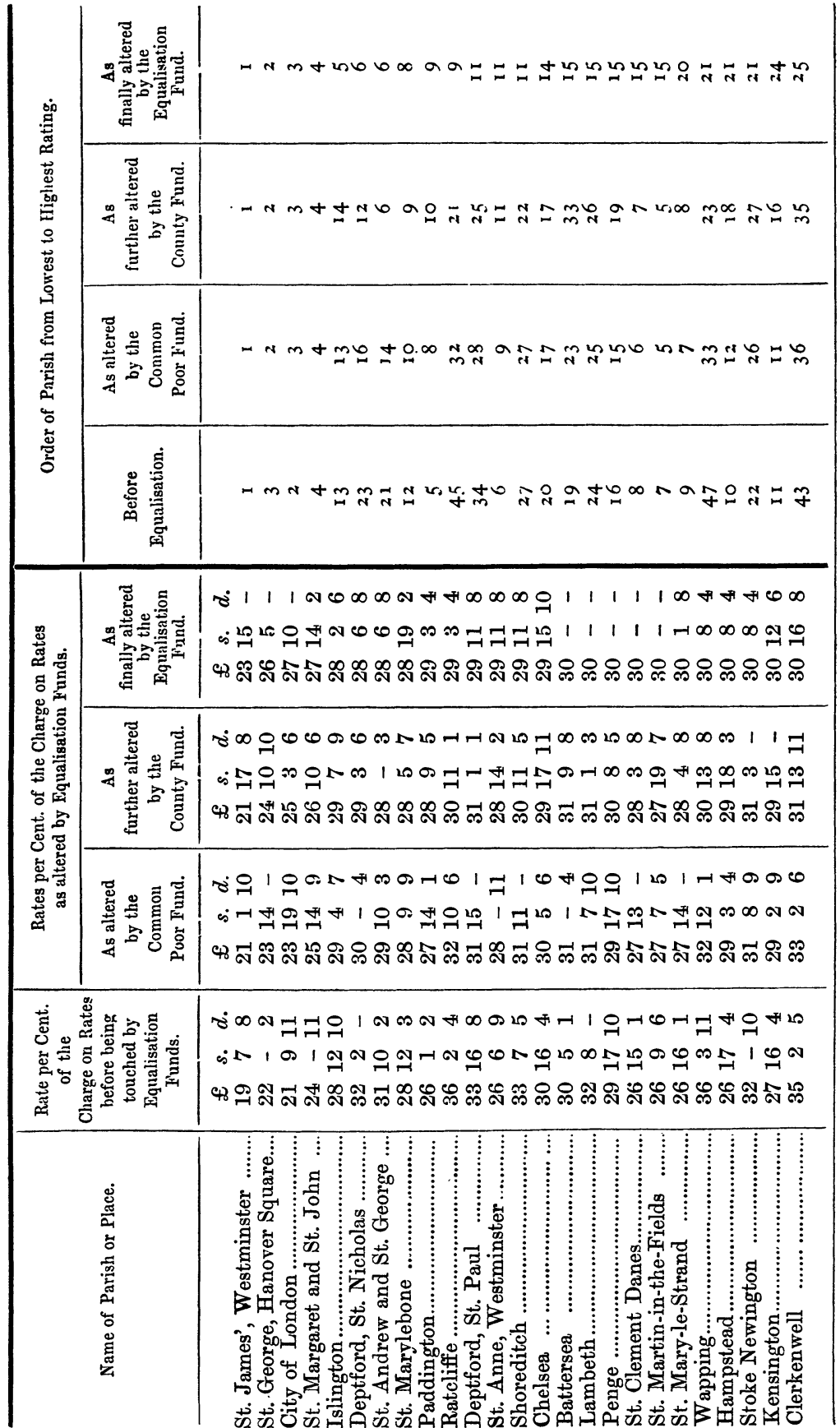




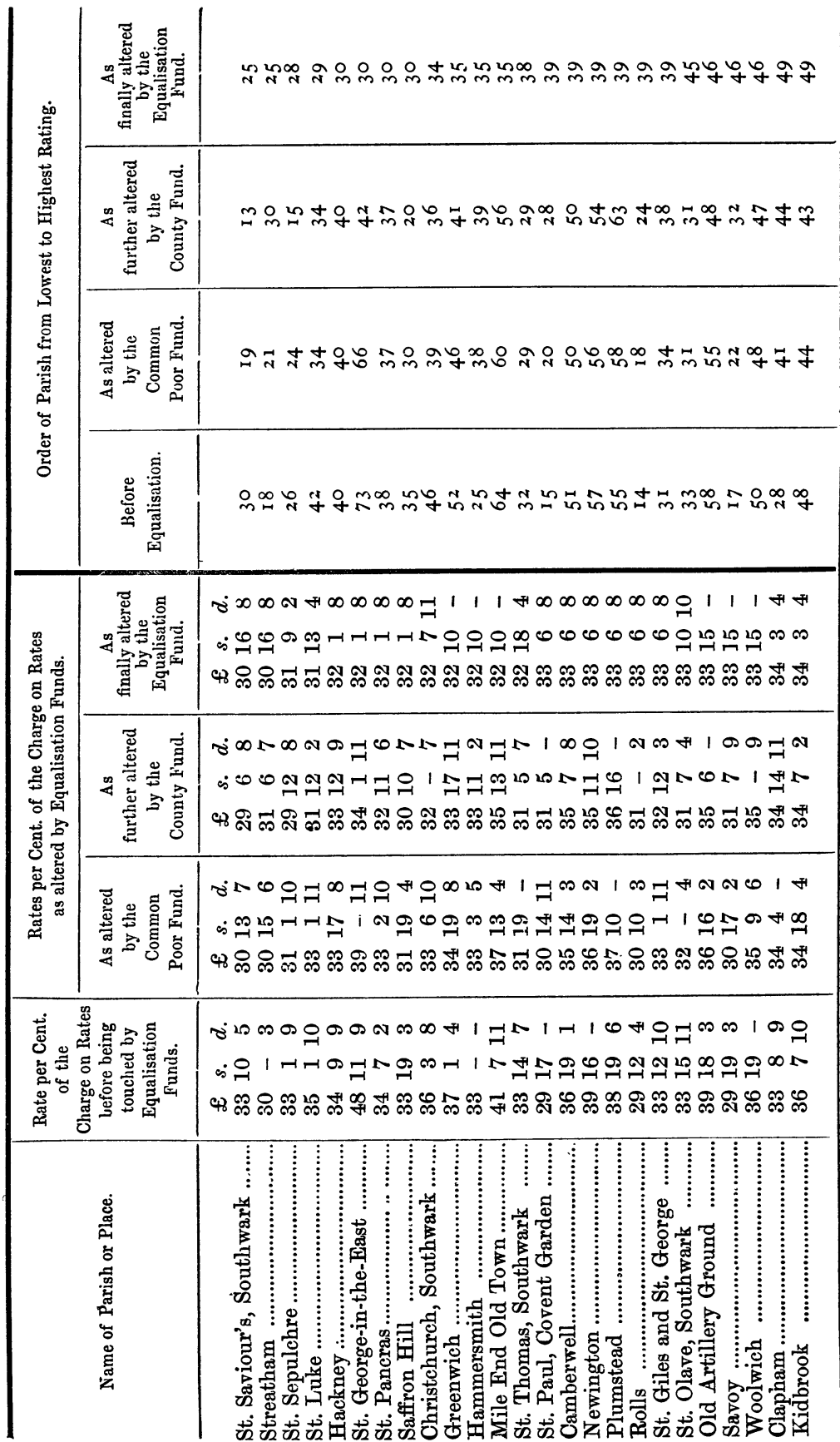

VOL. LXI. PART IIJ. 


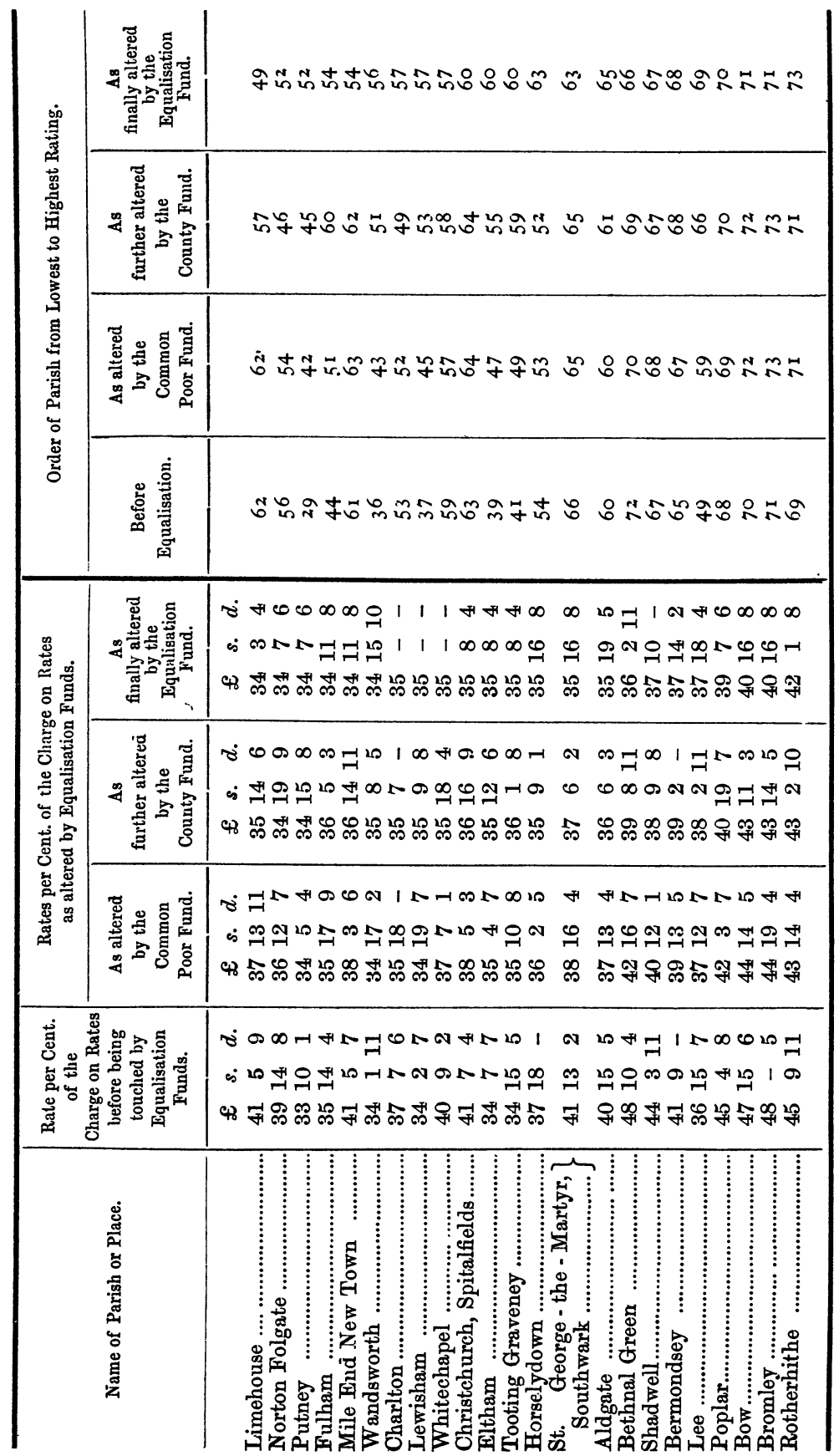


If therefore the units of local administration as originally formed had been left to themselves, the range of rating would have been from $19 l .7 s .8 d$. per cent. in St. James, Westminster, to $48 l$. I Is. $9 d$. per cent. in St. George-in-the-East; whereas, in consequence of making local charges fall upon county funds, the range of rating is from 23l.15s. per cent. in St. James, Westminster, to $42 l$. $1 s .8 d$. in Rotherhithe. There has thus been a levelling up of the lowest rated parishes and a lessening of the highest rated parishes, and in no case is a local authority in London entirely independent. Of parishes which incur a different expenditure, and in consequence of equalisation bear the same rate, there are Paddington and Ratcliff; Deptford St. Paul, St. Anne and Shoreditch; Battersea, Lambeth, Penge, St. Clement Danes, and St. Martin; Clerkenwell, St. Saviour's, and Streatham; St. George-in-the-East and St. Pancras; Greenwich and Hammersmith; Camberwell, Newington, Plumstead, Rolls, and St. Giles and St George; Savoy and W.oolwich; Clapham and Kidbrook; Charlton and Lewisham; Eltham and Tooting; Horselydown and St. George-the-Martyr. But still the range of differentiation is great, and the causes of this will need a somewhat lengthy examination.

The effect of the equalisation funds, which is either to decrease the charge incurred or to impose an additional charge upon each parish, is as follows :-

\begin{tabular}{|c|c|c|c|c|c|c|c|c|c|c|c|c|c|c|}
\hline \multirow[t]{2}{*}{ Parish. } & \multicolumn{10}{|c|}{$\begin{array}{l}\text { Addition to }(+) \text { or Deduction from }(-) \text { the Charge on lates } \\
\text { incurred by the Parish } \\
\text { caused by the operation of the Equalisation Funds. }\end{array}$} & \multicolumn{4}{|c|}{$\begin{array}{l}\text { g. } \\
\text { ge on lites } \\
\text { Funds. }\end{array}$} \\
\hline & & $\begin{array}{l}\text { Com } \\
\text { Poor }\end{array}$ & $\begin{array}{l}\text { imon } \\
\text { Fund. }\end{array}$ & & nty & Gra & ants. & & $\begin{array}{l}\text { Squalisati } \\
\text { k'und. }\end{array}$ & & & Tot: & tal. & \\
\hline 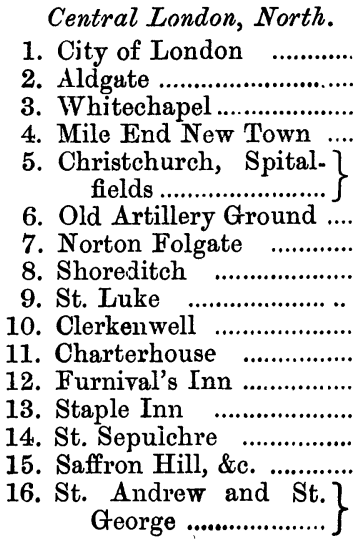 & $\begin{array}{l}- \\
- \\
- \\
- \\
- \\
- \\
- \\
- \\
-\end{array}$ & $\begin{array}{l}f \\
2 \\
3 \\
3 \\
3 \\
3 \\
3 \\
3 \\
1 \\
1 \\
1 \\
1 \\
1 \\
1 \\
1 \\
1 \\
1\end{array}$ & $\begin{array}{rr}2 & 1 \\
2 & 1 \\
16 & 5 \\
19 & 11 \\
19 & 11 \\
19 & 11 \\
19 & 11 \\
19 & 11 \\
19 & 11 \\
19 & 11 \\
19 & 11\end{array}$ & $\begin{array}{l}- \\
- \\
- \\
- \\
- \\
- \\
- \\
- \\
- \\
-\end{array}$ & $\begin{array}{l}\text { I } \\
\text { I } \\
- \\
\text { I } \\
\text { I } \\
\text { I } \\
\text { I } \\
\text { I } \\
\text { I } \\
\text { I }\end{array}$ & $\begin{array}{r}10 \\
12 \\
19 \\
9 \\
8 \\
9 \\
6 \\
6 \\
9 \\
8 \\
10\end{array}$ & $\begin{array}{r}d . \\
8 \\
1 \\
9 \\
7 \\
6 \\
2 \\
10 \\
7 \\
9 \\
7 \\
5 \\
10 \\
10 \\
2 \\
9 \\
-\end{array}$ & $\begin{array}{l}+ \\
- \\
- \\
- \\
- \\
- \\
- \\
- \\
+ \\
- \\
+ \\
+ \\
+ \\
+ \\
+ \\
+\end{array}$ & $\begin{array}{rr}f & s . \\
2 & 6 \\
- & 6 \\
- & 18 \\
2 & 3 \\
1 & 8 \\
1 & 11 \\
- & 12 \\
- & 19 \\
- & 1 \\
- & 17 \\
2 & 5 \\
2 & 2 \\
2 & 7 \\
1 & 16 \\
1 & 11 \\
- & 6\end{array}$ & $\begin{array}{l}-\overline{3} \\
9 \\
2 \\
3 \\
7 \\
- \\
3 \\
6 \\
1 \\
5\end{array}$ & $\begin{array}{l}- \\
- \\
- \\
- \\
- \\
- \\
- \\
- \\
- \\
-\end{array}$ & $\begin{array}{l}6 \\
5 \\
3 \\
3 \\
4 \\
1 \\
1 \\
- \\
\text { I } \\
1\end{array}$ & $\begin{array}{r}3 \\
7 \\
15 \\
8 \\
5 \\
3 \\
4 \\
19 \\
12 \\
17\end{array}$ & ${ }_{1}^{d}$ \\
\hline
\end{tabular}




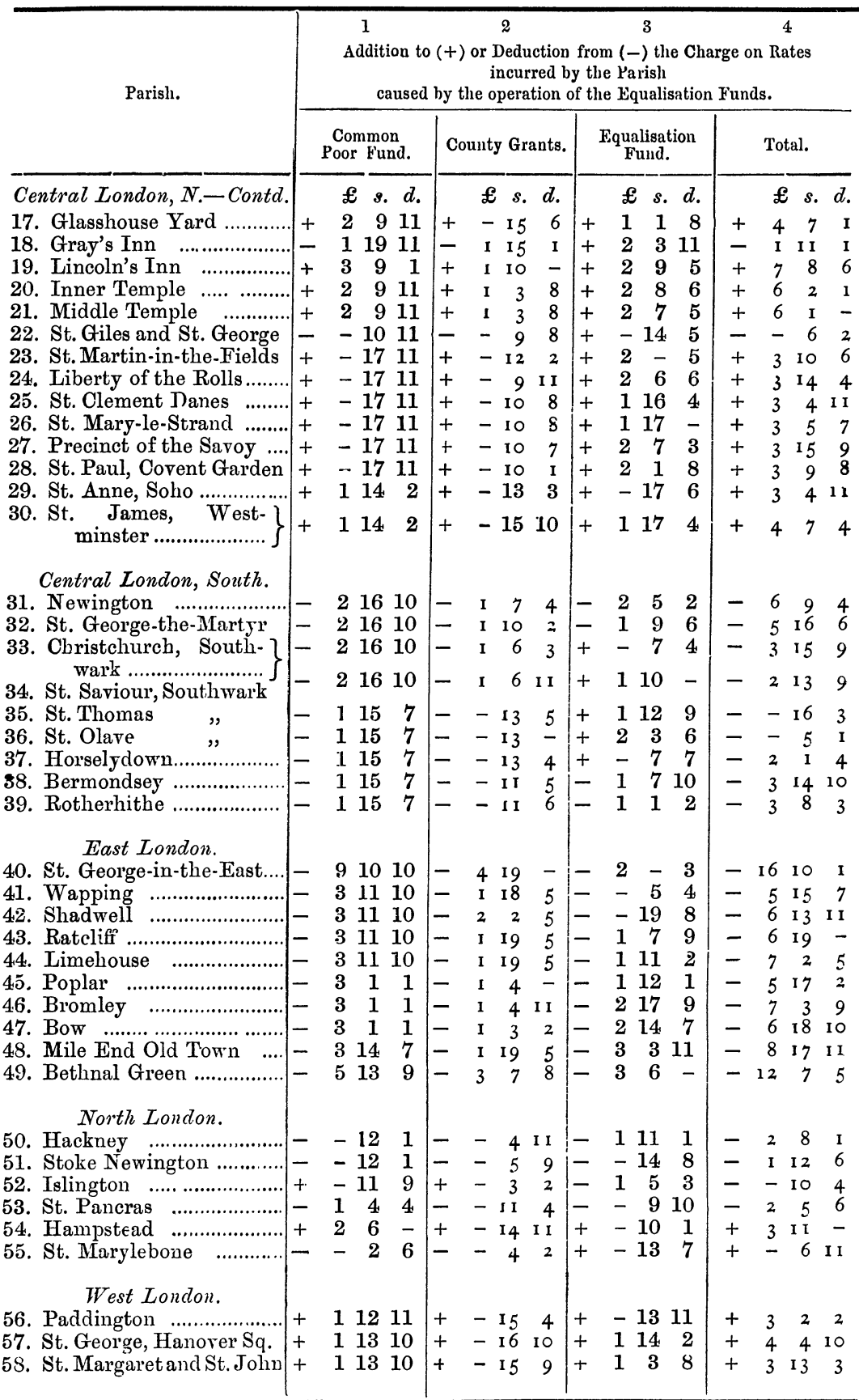




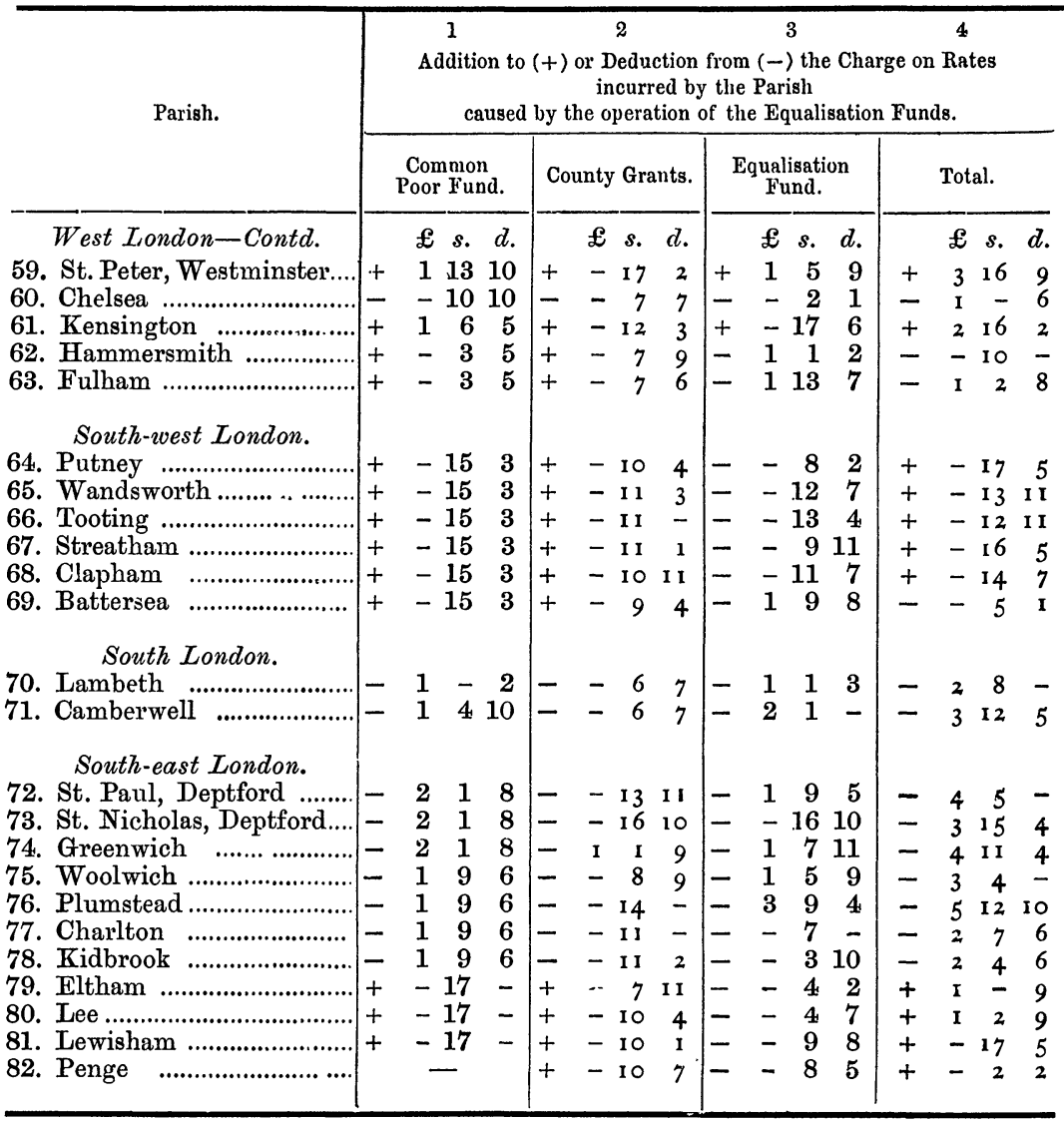

Now the question of whether local taxation falls equally upon the taxpayer, does not arise with the appropriations from imperial taxes, nor with the local indirect taxation. These systems of local taxation are governed by other considerations, and in any case they must be dealt with separately and from a different point of view to that of direct local taxation. The effect of direct local taxation when it reaches the taxpayer is the material matter for consideration by local taxing authorities.

It will be seen from the following table that the differentiation of rates in the several parishes of London is considerable, ranging from $23 l$. I $5 s$. per cent. to $42 l$. Is. $8 d$. per cent. of rateable value. 


\begin{tabular}{|c|c|c|c|c|c|}
\hline \multirow{3}{*}{ Name of Parish or Place. } & \multicolumn{2}{|c|}{$\begin{array}{c}\text { Rates per Cent. } \\
\text { of Rateable Value, } \\
1895-96 .\end{array}$} & \multicolumn{3}{|c|}{$\begin{array}{c}\text { Amount in } \\
\text { Excess of } \\
\text { Lowest Rating. }\end{array}$} \\
\hline & $\notin s$. & $d$. & $£$ & $s$. & $d$. \\
\hline & 2315 & & & - & \\
\hline St. George, Hanover Square & 265 & - & 2 & 10 & - \\
\hline 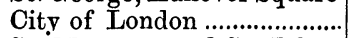 & 2710 & - & 3 & 15 & - \\
\hline St. Margaret and St. John & 2714 & 2 & 3 & 19 & 2 \\
\hline Islington & 282 & 6 & 4 & 7 & 6 \\
\hline Deptford St. Nicholas ....... & 286 & 8 & $\begin{array}{l}4 \\
4\end{array}$ & I I & 8 \\
\hline St. Andrew and St. George & 286 & 8 & $\begin{array}{l}4 \\
4\end{array}$ & I I & 8 \\
\hline St. Marylebone ......................... & 2819 & 2 & $\begin{array}{l}4 \\
5\end{array}$ & 4 & 2 \\
\hline 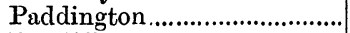 & 293 & 4 & 5 & 8 & 4 \\
\hline Ratcliff & 293 & 4 & $\begin{array}{l}5 \\
5\end{array}$ & 8 & $\begin{array}{l}4 \\
4\end{array}$ \\
\hline Deptford St. Paul ....................... & 2911 & 8 & $\begin{array}{l}5 \\
5\end{array}$ & 16 & $\begin{array}{l}4 \\
8\end{array}$ \\
\hline St. Anne, Westminster......... & 2911 & 8 & $\begin{array}{l}5 \\
5\end{array}$ & 16 & 8 \\
\hline 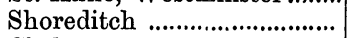 & 2911 & 8 & $\begin{array}{l}5 \\
5\end{array}$ & 16 & 8 \\
\hline 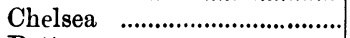 & 2915 & 10 & 6 & - & 10 \\
\hline 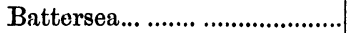 & $30-$ & - & 6 & 5 & - \\
\hline 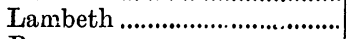 & $30-$ & - & 6 & $\begin{array}{l}5 \\
5\end{array}$ & - \\
\hline 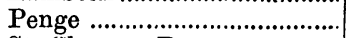 & 30 & - & 6 & 5 & - \\
\hline St. Clement Danes...................... & 30 & - & 6 & 5 & - \\
\hline St. Martin-in-the-Fields .... & 30 & - & 6 & 5 & - \\
\hline St. Mary-le-Strand .............. & 30 & 8 & 6 & 6 & 8 \\
\hline 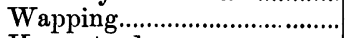 & 30 & 4 & 6 & 13 & 4 \\
\hline 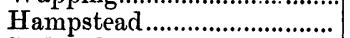 & 30 & 4 & 6 & 13 & 4 \\
\hline Stoke Newington & 308 & 4 & 6 & I3 & $\begin{array}{l}4 \\
4\end{array}$ \\
\hline 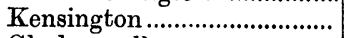 & 3012 & 6 & 6 & 17 & 6 \\
\hline 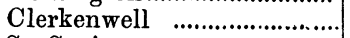 & 3016 & 8 & 7 & I & 8 \\
\hline 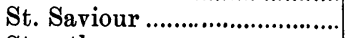 & 3016 & 8 & 7 & I & 8 \\
\hline 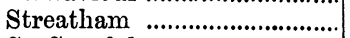 & 3016 & 8 & 7 & $\mathbf{I}$ & 8 \\
\hline 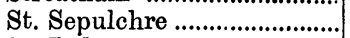 & 319 & 2 & 7 & 14 & 2 \\
\hline 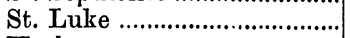 & 3113 & 4 & 7 & 18 & 4 \\
\hline Hackney ........................................ & 321 & 8 & 8 & 6 & 8 \\
\hline St. George-in-the-East ......... & 321 & 8 & 8 & 6 & 8 \\
\hline 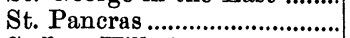 & 32 & 8 & 8 & 6 & 8 \\
\hline Saffron Hill, \&c......................... & 321 & 8 & 8 & 6 & 8 \\
\hline Christchurch, Southwark .... & 327 & 11 & 8 & I 2 & I I \\
\hline 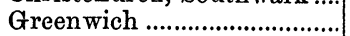 & 3210 & - & 8 & 15 & - \\
\hline 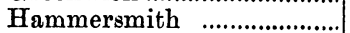 & 3210 & - & 8 & 15 & - \\
\hline Mile End Old Town .............. & 3210 & - & 8 & 15 & - \\
\hline St. Thomas, Southwark......... & 3218 & 4 & 9 & 3 & 4 \\
\hline St. Paul, Covent Garden .... & 336 & 8 & $\begin{array}{l}9 \\
9\end{array}$ & i I & 8 \\
\hline 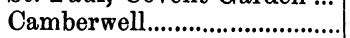 & 336 & 8 & 9 & II & 8 \\
\hline 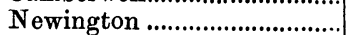 & 33 & 8 & 9 & II & 8 \\
\hline Plumstead & 33 & 8 & 9 & II & 8 \\
\hline Rolls & 33 & 8 & 9 & I & 8 \\
\hline St. Giles and St. George .... & 336 & 8 & 9 & 11 & 8 \\
\hline St. Olave, Southwark ......... & 3310 & 10 & 9 & 15 & 10 \\
\hline Old Artillery Ground .......... & 3315 & - & 10 & - & - \\
\hline Savoy ……................................... & 3315 & - & 10 & - & - \\
\hline 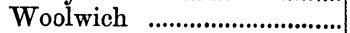 & 3315 & - & 10 & - & - \\
\hline Clapham & $34 \quad 3$ & 4 & 10 & 8 & 4 \\
\hline 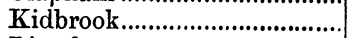 & $34 \quad 3$ & 4 & 10 & 8 & 4 \\
\hline Limehouse & $34 \quad 3$ & 4 & 10 & 8 & 4 \\
\hline 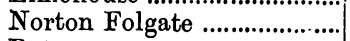 & 347 & 6 & 10 & 12 & 6 \\
\hline Putney & 347 & 6 & 10 & 12 & 6 \\
\hline Fulham .................................. & 34,11 & 8 & 10 & I 6 & 8 \\
\hline Mile End New Town............. & 3411 & 8 & 10 & 16 & 8 \\
\hline 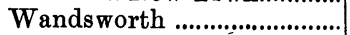 & 34,15 & 10 & 11 & - & 10 \\
\hline
\end{tabular}




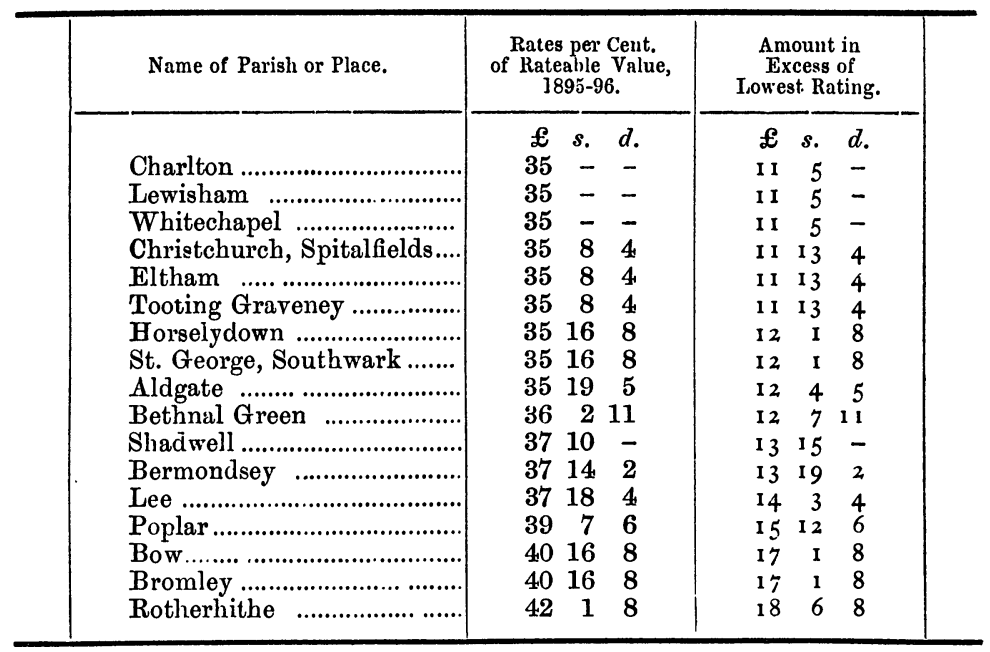

The causes of differentiation in rating operate both through the county and the parish, but by far the most important are those which operate through the parish.

The first cause of differentiation to be considered is the exemption from county rating. This occurs in the following cases :-

County rate (special): The City of Iondon, Inner Temple, and Middle Temple.

Asylums Board charge: Lincoln's Inn, Gray's Inn, Inner Temple, Middle Temple, and Penge.

Common Poor Fund charge : Penge.

The exemption from the special county rate is in London not due to special areas being benefited by special expenditure out of rates, and in consequence being charged with a special rate, but to a distinct exemption of the city of London from taking its share in the administrative organisation of the county. It causes differentiation of rating between the group of parishes contained in the county of London on the one hand, and the group of parishes contained in the city of London on the other hand. The city of London administers certain county services within its own area, and bears the charges therefor instead of sharing the administration and the cost with the rest of the county. This therefore resolves itself into a question of proportion: what additional charge for the present exempted services would the whole county have to bear in proportion to the additional rateable value which would be brought into common rating? In the year 1895-96 the charges incurred for these services were as follows :- 
(a) By the Corporation of the city.

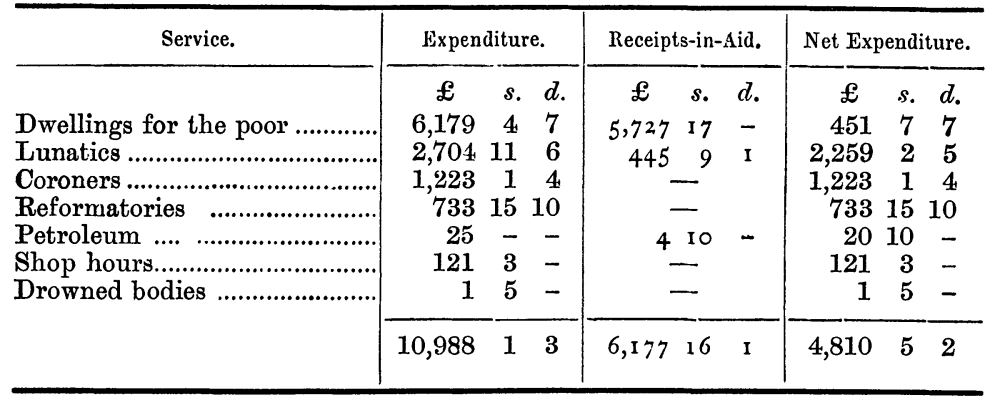

(b) By the Commissioners of Sewers.

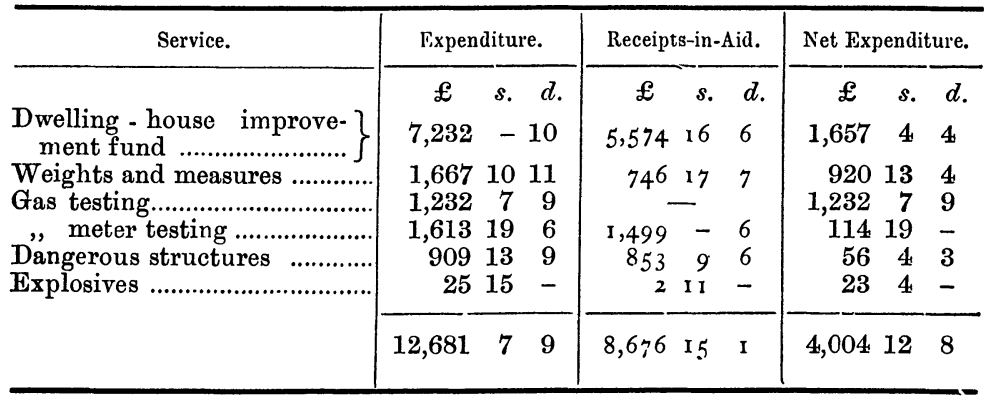

Assuming that no saving would arise from uniform administration, and that the whole of this expenditure would fall upon the entire county, the position of things would be :-

Charges now paid for by the special county rate $£ \quad$ s. $\quad d$. $\left.\begin{array}{l}\text { for corresponding services now paid by the } \\ \text { City Corporation and by the Commissioners of } \\ \text { Sewers (as above) }\end{array}\right\}$ 300,057 I3 3 8,81417 10

Total charges to be met by the entire county.... 308,872 iा 1

This amount calculated on the rateable value of the whole county is equivalent to a rate of $2 \cdot 166 d$. in the $\mathscr{E}$, or $18 s .0 .61 d$. per cent. of rateable value.

The differentiation in rating as between the city and county by reason of this exemption works out as follows :-

(a) The County-

Rate now levied-per cent. of rateable value

" which would be levied but for the exemption $\}$

"-per cent. of rateable value

Differentiated rate charged upon the county by reason of the exemption of the city-per cent. $\}-$ I 11.39 of rateable value 
(b) The City-

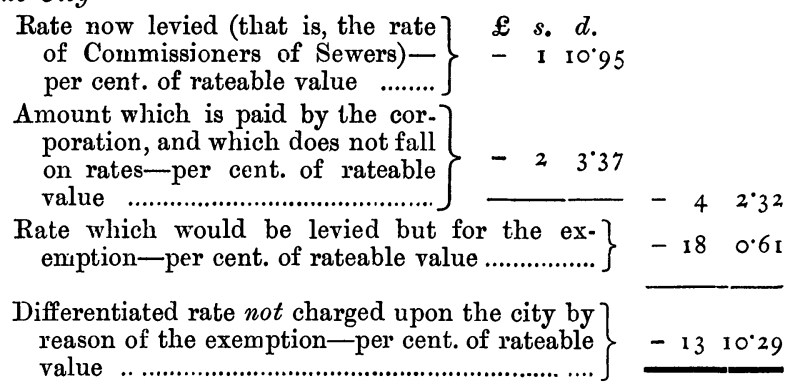

The Asylums Board charge is not levied from Lincoln's Inn, Gray's Inn, Inner 'Temple, Middle Temple, and Penge. Assuming that the inclusion of Penge in the Asylums Board district would be to correspondingly increase the charge to the amount of contribution, the exemption of the Inns of Court may be considered as the only cause of differentiation under this head. This exemption causes an increased charge equivalent to a rate of $0.65 d$. per cent. upon rateable value to fall upon the rest of the parishes in the county. The four Inns of Court escape taxation to the extent of $1 l .4 s .99^{\circ} 8 d$. per cent. of their rateable value, and the rest of the county is charged with $0.65 \mathrm{~d}$. per cent. of its rateable value more than it would be if the Asylums Board charge were levied equally over the county."

The common poor fund charge is not levied upon Penge. It is impossible to say with any certainty what the effect would be if Penge were to be brought into the metropolitan poor law system and separated from Croydon, but it is probable that it would gain from the common poor fund at the expense of the rest of London.

Putting these exemptions together, the city of London gains 13s. 10.29d. per cent. by its exemption from the special county rate, and loses $0^{6} 65 d$. per cent. by the exemption of the Inns of Court from the Asylums Board charge; the Inner and Middle Temple gain $18 s .0^{\circ} 6 \mathrm{r} d$. per cent., less $2 s .3 .37 d$., or $15 s .9 .24 d$. per cent., by their exemption from the special county rate (as they are not rated to the Commissioners of Sewers), and 1 l. $4^{s .9} 9^{\circ} 9^{8} d$. per

4 Although the Inns of Court do not contribute to the expenses of the Metropolitan Asylums Board, a peculiar arrangement is in force by which Gray's Inn contributes to the common charges of Holborn Union, and the Temple contribute to the common charges of the City of London Union, the common charges in both cases including the charge of the Asylums Board on the unions. The benefit of the exemption, therefore, instead of accruing wholly to the places exempted, is shared with the unions to which they thus contribute. 'The effect of this arrangement is not, however, included in the figures used above, because being caused by a technical process which does not appear to be founded upon statutory provisions, it may, perhaps, be counteracted by other similar operations. 
cent. by their exemption from the Asylums Board charge; Lincoln's Inn and Gray's Inn gain $\mathrm{r} l .4^{s} .9^{\circ} 98 d$. per cent. by the exemption from the Asylums Board charge, and lose is. I I $39 d$. per cent. by reason of the exemption of the city from the special county rate; Penge and the rest of the county of London lose Is. I I'39d. per cent. by reason of the exemption of the city from the special county rate, and $0.65 d$. by reason of the exemptions from the Asylums Board charge. Put into tabular form, the figures are as follows:-

\begin{tabular}{|c|c|c|c|}
\hline \multirow{8}{*}{ 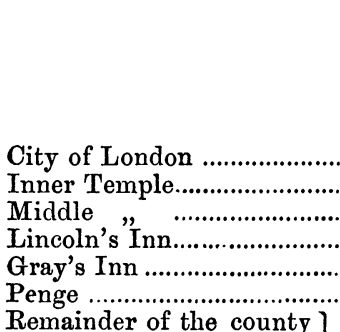 } & $\begin{array}{l}\text { Increased Rating- } \\
\text { per Cent. } \\
\text { of Rateable Value. }\end{array}$ & $\begin{array}{l}\text { Decreased Rating- } \\
\text { per Cent. } \\
\text { of Rateable Value. }\end{array}$ & $\begin{array}{c}\text { Net Result per Cent. } \\
\text { of } \\
\text { Rateable Value. }\end{array}$ \\
\hline & s. $\quad d$. & $£ s . \quad d$. & $£$ s. $\quad d$. \\
\hline & 0.65 & -1310.29 & --13 \\
\hline & $\ldots$. & $2-7.22$ & $-2-$ \\
\hline & & $-\quad 3.22$ & $-2-7 \cdot 22$ \\
\hline & $1 \dddot{11} \cdot 39$ & 49.98 & $\begin{array}{lll}-1 & 2 & 10.59\end{array}$ \\
\hline & $1 \quad 11 \cdot 39$ & I 49.98 & -12210.59 \\
\hline & 20.04 & .... & +-20.04 \\
\hline $\left.\begin{array}{l}\text { Remainder of the county } \\
\text { of London }\end{array}\right\}$ & 0.04 & $\ldots$ & +-20.04 \\
\hline
\end{tabular}

The remaining causes of differentiation operate between individual parishes, and not between groups of parishes in particular areas.

Certain classes of property are allowed partial or total exemption from rating, and the extent of this within each parish in proportion to the total rateable value of the parish causes differentiation of rating.

These properties consist of (1) properties at and below 20l. in value which, by 32 and 33 Vict., cap. 41, are allowed a deduction of 15 per cent. from the rates when the rates are paid by the landlord, and a further deduction up to a maximum of 15 per cent. if rates are paid whether the premises are occupied or empty; (2) property not occupied, which in the city of London is exempt from rating to the extent of one-half, and in the rest of London wholly exempt; (3) land in respect of which only one-fourth of the sewers rate is levied, and certain other property, chiefly land, in respect of which only one-fourth of the lighting rate is levied, certain classes of property exempt from rating by statute, certain special property exempt from rating by private Act, and certain property partially exempt from rating.

Property at or under $20 l$. rateable value bears a very different proportion to the total property in different parishes. The highest and lowest proportions are set out in the following table:- 


\begin{tabular}{|c|c|c|c|}
\hline \multicolumn{2}{|c|}{ Highest Proportions. } & \multicolumn{2}{|l|}{ Lowest Proportions. } \\
\hline Parish. & $\begin{array}{l}\text { Proportion } \\
\text { per Cent. of } \\
\text { Total. }\end{array}$ & Parish. & $\begin{array}{l}\text { Proportion } \\
\text { per Cent. of } \\
\text { Total. }\end{array}$ \\
\hline 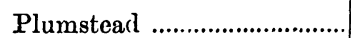 & 52 & St. Paul, Covent Garden & .04 \\
\hline 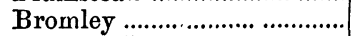 & 45 & 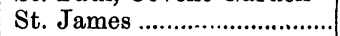 & $\cdot{ }_{\mathrm{I}}^{\top}$ \\
\hline Bethnal Green .......................... & 39 & City of London & .2 \\
\hline Mile End New Town & 38 & Rolls ......................................... & $\cdot 2$ \\
\hline 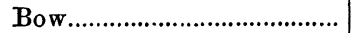 & 36 & St. Martin & $\cdot 2$ \\
\hline Mile End Old Town............... & 35 & St.George, Hanover Square & I \\
\hline Tooting & 35 & St. Clement Danes ............... & I \\
\hline 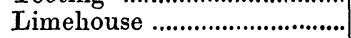 & 32 & 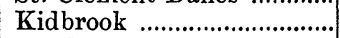 & $\mathbf{I}$ \\
\hline Bermondsey & $3 \mathbf{I}$ & 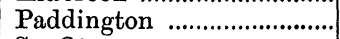 & $i$ \\
\hline Rotherhithe …...................... & 29 & St. Olave & i \\
\hline Deptford St. Paul ..................... & 29 & 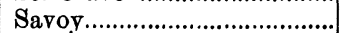 & I \\
\hline St. George-in-the-East .......... & 27 & St. Mary-le-Strand .......... & I \\
\hline 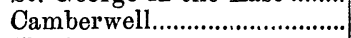 & 27 & Old Artillery Ground .......... & 2 \\
\hline 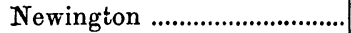 & 27 & St. Sepulchre ……….......... & 2 \\
\hline 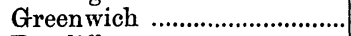 & 26 & St. Giles and St. George.... & 2 \\
\hline 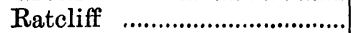 & 26 & Hampstead ............................ & 2 \\
\hline 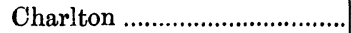 & 25 & Kensington ............................... & 3 \\
\hline 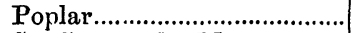 & 25 & 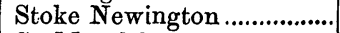 & 3 \\
\hline St. George-the-Martyr ......... & 24 & 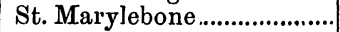 & 3 \\
\hline 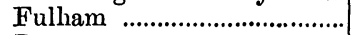 & 24 & 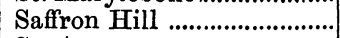 & 4 \\
\hline Battersea & 24 & 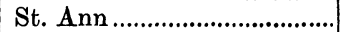 & 4 \\
\hline 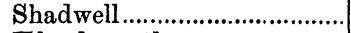 & 23 & Wapping & 4 \\
\hline 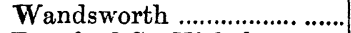 & 20 & 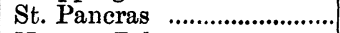 & 4 \\
\hline Deptford St. Nicholas ......... & 20 & Norton Folgate & 5 \\
\hline Woolwich ……………............. & 20 & Aldgate & 6 \\
\hline 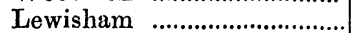 & 17 & 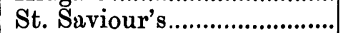 & 6 \\
\hline 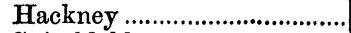 & 16 & Islington & 6 \\
\hline 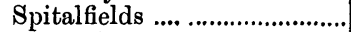 & I 5 & St. Andrew & 7 \\
\hline 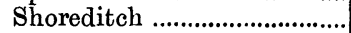 & 15 & 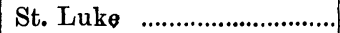 & 8 \\
\hline Hammersmith & 15 & 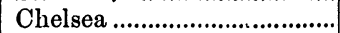 & 9 \\
\hline St. Margaret ............................... & 14 & 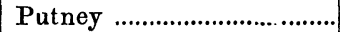 & 9 \\
\hline 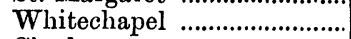 & 13 & Christchureh & 10 \\
\hline Clapham & 13 & 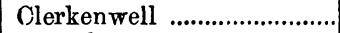 & 10 \\
\hline 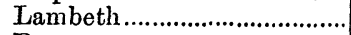 & 13 & 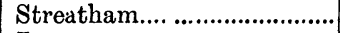 & II \\
\hline Penge .................................... & I3 & 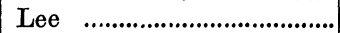 & I I \\
\hline 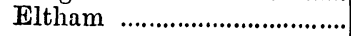 & 12 & & \\
\hline
\end{tabular}

In addition to these causes of differentiation there are other causes which depend upon matters of assessment. These cannot be reduced to statistics, because there are practically no data for the purpose, although the subject is one of considerable importance to the rating units of London. But I can pause here and make some sort of a total, because the differentiation caused by all matters connected with assessments, that is to say, exemptions from rating, loss on empty properties, inequality of assessment, \&c., can be given by means of a very elaborate calculation. This result is as follows :- 


\begin{tabular}{|c|c|c|c|c|c|}
\hline Parish. & $\begin{array}{r}\text { Inc } \\
\text { i } \\
\text { due t } \\
\text { Allon } \\
\text { of I }\end{array}$ & $\begin{array}{l}\text { rease in } \\
\text { teach P } \\
\text { Exemp } \\
\text { ances- } \\
\text { ateable } \\
1895-9\end{array}$ & $\begin{array}{l}\text { Rating } \\
\text { Parish } \\
\text { ptions and } \\
\text {-percent. } \\
\text { Value. } \\
96 .\end{array}$ & Parish. & $\begin{array}{c}\text { Increase in Rating } \\
\text { in each Parish } \\
\text { due to Exemptions and } \\
\text { Allowrances-per Cent. } \\
\text { of Rateable Value. } \\
1895-96 .\end{array}$ \\
\hline 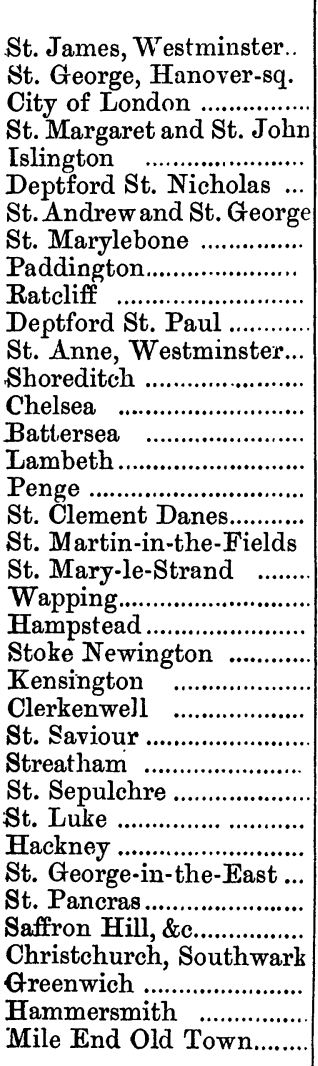 & - & $\begin{array}{lr}2 & s . \\
- & 6 \\
1 & 3 \\
- & 11 \\
- & 5 \\
- & 16 \\
1 & 9 \\
1 & 7 \\
1 & 12 \\
2 & 5 \\
- & 19 \\
1 & 12 \\
1 & 7 \\
2 & 8 \\
1 & 12 \\
1 & 18 \\
1 & 4 \\
1 & 19 \\
- & 6 \\
1 & - \\
- & 17 \\
- & 15 \\
- & 13 \\
- & 6 \\
2 & 10 \\
1 & - \\
- & 18 \\
1 & 5 \\
2 & 5 \\
1 & 16 \\
2 & 1 \\
2 & 9 \\
1 & 9 \\
2 & 12 \\
2 & 2 \\
2 & 5 \\
2 & 14 \\
1 & 10\end{array}$ & $\begin{array}{r}d \\
4 \\
7 \\
3 \\
5 \\
8 \\
2 \\
5 \\
8 \\
4 \\
5 \\
4 \\
5 \\
2 \\
10 \\
9 \\
7 \\
4 \\
11 \\
6 \\
6 \\
11 \\
11 \\
7 \\
9 \\
10 \\
8 \\
10 \\
4 \\
2 \\
4 \\
1 \\
8 \\
4 \\
2 \\
5 \\
- \\
9\end{array}$ & 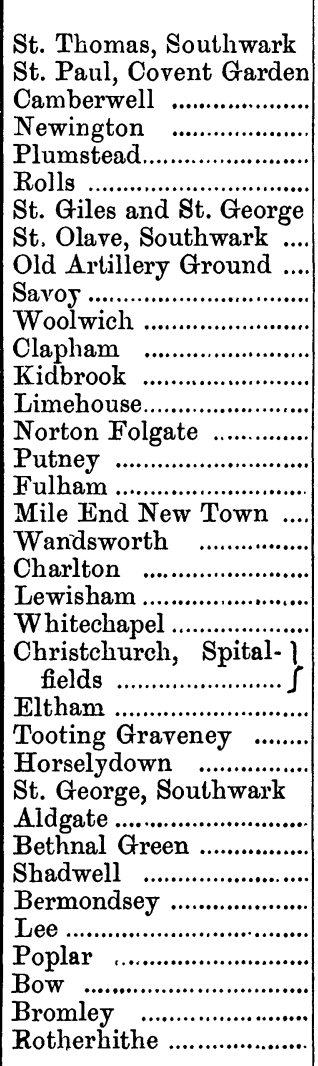 & 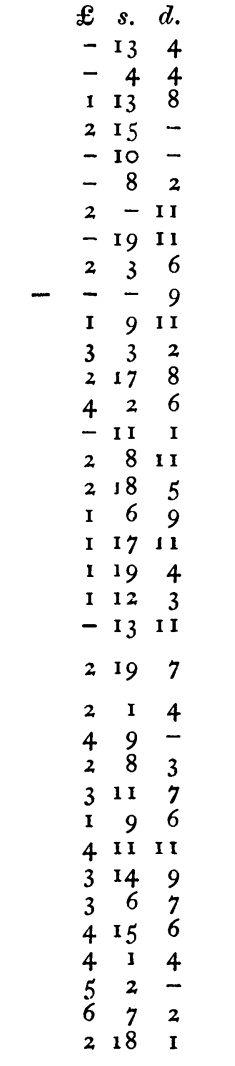 \\
\hline
\end{tabular}

The next causes of differentiation of rates relate to a different class of subject altogether. There is first the early or late date at which parishes or districts in London have become equipped for the purposes of local government. Speaking generally the central parishes were in a fairly forward state at the time of the passing of the Metropolis Management Act in 1855, while the outlying parishes had hardly begun the work of paving, sewerage, workhouses, and other services necessary to bring an area up to the level of the requirements. Since 1855 other necessities have arisen, and some parishes and districts have supplied themselves with those necessities, while others have not; and in case of the riverside 
areas the necessity of embanking has arisen, which does not occur $\mathrm{n}$ other parishes.

The position of the parishes in regard to these matters is practically tested by the loan operations of the various authorities. The following parishes have the highest rate of loan charge :-

\begin{tabular}{|c|c|c|}
\hline & $\begin{array}{c}\text { Rate in the } \& \\
\text { of Loan Charge, } \\
1895-96 .\end{array}$ & $\begin{array}{l}\text { Percentage of } \\
\text { Loans Outstanding to } \\
\text { Rateable Value. }\end{array}$ \\
\hline Bow & $\underset{11 \cdot 38}{d .}$ & \\
\hline St. George, Southwark & $\begin{array}{l}11 \cdot 38 \\
11 \cdot 35\end{array}$ & $\begin{array}{l}45^{\circ} 55 \\
21 \cdot 97\end{array}$ \\
\hline 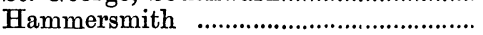 & $11 \cdot 32$ & $29 \cdot 22$ \\
\hline Fulham & $10 \cdot 38$ & 3150 \\
\hline 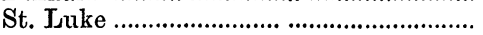 & $10 \cdot 27$ & $41 \cdot 89$ \\
\hline 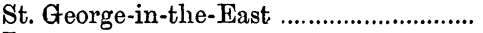 & 8.09 & $34^{\circ} 68$ \\
\hline Lee & 8.00 & $29^{\circ} 29$ \\
\hline 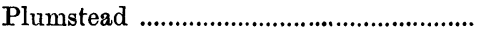 & $7 \cdot 66$ & 28.98 \\
\hline Bethnal Green & $7 \cdot 57$ & $28 \cdot 12$ \\
\hline Putney & $7 \cdot 55$ & 26.06 \\
\hline St. Martin-in-the-Fields & $7 \cdot 41$ & $29^{\circ} 29$ \\
\hline Poplar & $7 \cdot 03$ & $26 \cdot 18$ \\
\hline 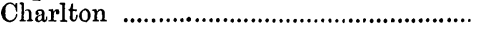 & $7 \cdot 02$ & $18 \cdot 00$ \\
\hline
\end{tabular}

These examples are in contrast with the following cases of the lowest rate of loan charge :-

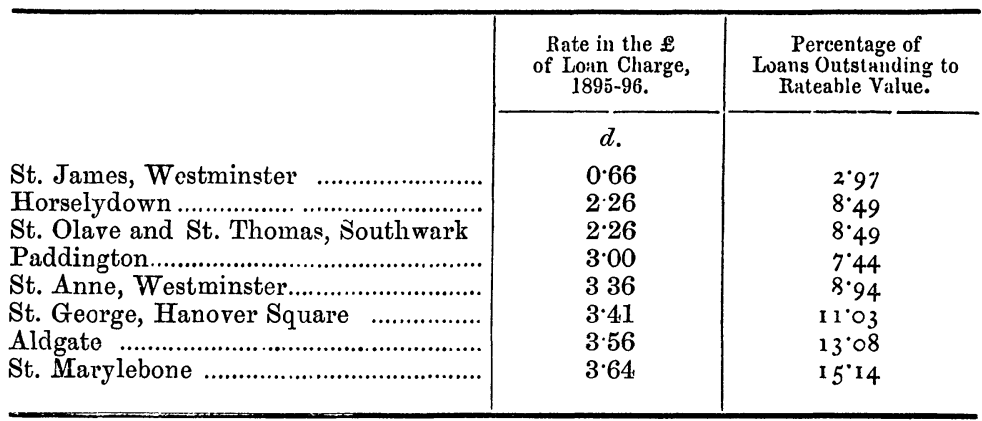

The differences in these two groups of parishes are due to loans for permanent works to meet requirements for purposes common to all London being in active operation in the first group, and either paid off or nearing the finish in the second group; to loans for libraries, baths, cemeteries, electric lighting, \&c., having been incurred by particular localities and not by others; to loans for improvement works raised in some localities and not in others; to loans raised in some localities for works of current purposes, such as wood paving, the equivalent charge for which in other localities is met out of current revenue; and to loans for administrative 
purposes, such as town halls, wharves, depôts, \&c., which do not occur in all places.

The parish of St. James, Westminster, is the best example of places where the lowest charge for debt is incurred. It has now no municipal loans. It incurred a loan for wood and asphalte paving in 1883, and finished paying it off in 1896; it incurred a lnan for the town hall in 1862, and finished paying it off in 1881 . It bears its proportion of poor law loans, and it has a small loan for baths.

The comparative figures, with a view of showing the different stages in municipal and poor law equipment at which each parish has arrived, would be very valuable as an important element in the differentiation of rates. But the information for such a purpose is not readily to hand.

The next cause of differentiation of rates arises from inequalities in local administration. Some parishes or unions may administer their poor law so as to give a larger amount of out-door relief than other parishes or unions, and as the whole of out-door relief remains a parish charge, and is unaffected by the equalisation under the common poor fund, this difference operates upon the parish rates; some parishes may maintain parks and open spaces, baths and washhouses, libraries, and other optional services, which other parishes may not; some parishes also may by their adjoining the river have to incur charges in respect of embankment which do not fall upon other parishes. The differentiation of rates in these cases takes the shape of increasing the rates where these services are administered, and the following table shows the result in each parish :-

\begin{tabular}{|c|c|c|c|c|c|c|c|}
\hline \multirow[b]{2}{*}{ Name of Parish. } & \multicolumn{7}{|c|}{$\begin{array}{c}\text { Charges in respect of the Undermentioned Services, causing Differentiation of Rates } \\
\text { (per Cent. of Rateable Value). }\end{array}$} \\
\hline & $\begin{array}{l}\text { Out-door } \\
\text { Reiief. }\end{array}$ & $\begin{array}{l}\text { Open Spaces } \\
\text { maintained } \\
\text { by Local } \\
\text { Authorities. }\end{array}$ & Burial. & $\begin{array}{c}\text { Baths } \\
\text { and } \\
\text { Wa:hlihouses. }\end{array}$ & Libraries. & $\begin{array}{c}\text { Other } \\
\text { Special } \\
\text { Serrices. }\end{array}$ & Total. \\
\hline & $£$ s. $\quad d$. & s. $\quad d$. & s. $\quad d$. & $\begin{array}{lll}£ & s . & d .\end{array}$ & $s . d$. & És. d & $£$ s. $d$. \\
\hline St. James, Westminster & -14 & - & - & $-1-$ & - & -11 & -35 \\
\hline $\left.\begin{array}{l}\text { St. George, Hanover } \\
\text { Square ........................ }\end{array}\right\}$ & -27 & -3 & - & -86 & 4. 7 & - & -1511 \\
\hline City of London & -4 & 410 & - & - & 一 & -3 & -129 \\
\hline 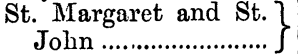 & -27 & -7 & -2 & $-14 \quad 4$ & 84 & - & $\begin{array}{lll}1 & 6 & 2\end{array}$ \\
\hline 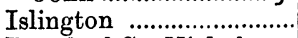 & 18 & 15 & - & -102 & - & - & $2-9$ \\
\hline Deptford St. Nicholas... & 1106 & 29 & 一 & - & - & $-\quad-$ & 113 \\
\hline $\begin{array}{l}\text { St. Andrew and St. } \\
\text { George }\end{array}$ & -158 & -3 & - & 一 & 311 & $-\quad-$ & $1--$ \\
\hline St. Marylebone & -8 & -11 & 33 & -311 & - & -6 & $\begin{array}{lll}1 & 3 & 1\end{array}$ \\
\hline Paddington ........................... & -36 & 25 & - & -410 & - & - & -1010 \\
\hline
\end{tabular}




\begin{tabular}{|c|c|c|c|c|c|c|c|c|}
\hline \multirow[b]{2}{*}{ Name of Parish. } & \multicolumn{8}{|c|}{$\begin{array}{l}\text { Charges in respect of the Undermentioned Services, causing Differentiation of Rates } \\
\text { (per Cent. of Rateable Value). }\end{array}$} \\
\hline & $\begin{array}{l}\text { Out-door } \\
\text { Relief. }\end{array}$ & $\begin{array}{l}\text { Open Spaces } \\
\text { naintained } \\
\text { by Local } \\
\text { Authorities. }\end{array}$ & Burial. & $\begin{array}{c}\text { Baths } \\
\text { and } \\
\text { Washhous }\end{array}$ & & Libraries. & $\begin{array}{c}\text { Other } \\
\text { Special } \\
\text { Services. }\end{array}$ & Total. \\
\hline & $£ \quad s . \quad d$. & s. $d$ & s. $d$. & \& s. $d$ & & s. $d$. & $£$ s. $d$. & \& s. $d$. \\
\hline Ratcliff ..................... & -142 & 11 & 一 & 一 & & - & $-\quad-8$ & -1511 \\
\hline Deptford St. Paul & 110 & $\overline{5}$ & - & -2 & 7 & - & $-\quad-1$ & 1137 \\
\hline St. Anne, Westminster & -1 & 1 & $3 \quad 3$ & - & & - & 1 & -7 \\
\hline Shoreditch .... & -13 & 2 & - & 4 & $\mathbf{5}$ & 59 & - & 15 \\
\hline 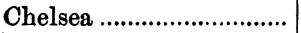 & -15 & 8 & - & 8 & 4 & 79 & - & 112 \\
\hline 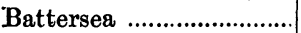 & -145 & 1 & 62 & 5 & 3 & 710 & - & 1141 \\
\hline Lambeth ............................... & 1810 & 3 & - & - & 9 & 711 & - & 11810 \\
\hline Penge & -184 & & - & - & & $7 \quad 1$ & - & 188 \\
\hline St. Clement Danes ......... & -7 & 1 & - & - & & - & -5 & -8 \\
\hline St. Martin-in-the-Fields & -7 & 2 & 一 & -11 & 10 & 84 & - & -19 \\
\hline St. Mary-le-Strand ........ & -7 & 11 & - & - & & - & 6 & $\begin{array}{ll}-15 & 1\end{array}$ \\
\hline Wapping .......................... & -14 & - & 一 & - & & - & - & -1810 \\
\hline pstead ……................... & -4 & 19 & - & 3 & 1 & $8-$ & 5 & $\begin{array}{ll}-17 & 7\end{array}$ \\
\hline Stoke Newington.............. & $\begin{array}{lll}1 & 4 & 7\end{array}$ & - & - & - & & 82 & - & 113 \\
\hline Kensingto & -210 & -6 & -11 & - & 3 & 310 & - & -13 \\
\hline ............ & -158 & 17 & - & - & & 107 & - & 18 \\
\hline St. Saviour ………….......... & -153 & - & -4 & -19 & 9 & 7 & 4 & 23 \\
\hline (........................... & -145 & -2 & 129 & - & & 81 & - & 115 \\
\hline St. Sepulchre & -158 & $-\mathbf{3}$ & 一 & - & & 311 & -2 & $1-$ \\
\hline St. Luke & -158 & $\mathbf{5}$ & 一 & - & & - & - & 11 \\
\hline Hackney & 147 & 2 & - & -16 & 2 & - & - & 25 \\
\hline St. George-in-the-East & 2110 & 3 & - & -2 & 1 & - & -2 & 29 \\
\hline & -125 & 25 & - & -11 & 11 & - & -17 & 114 \\
\hline Saffron Hill, \&c. .................. & -158 & - & - & - & & 311 & -- & $1-$ \\
\hline Christchurch,Southwark & -153 & - & 一 & - & & 710 & 1 & 212 \\
\hline ......................... & 1106 & 1 & - & $\mathbf{3}$ & 9 & - & - & 116 \\
\hline ersmith ........................ & -97 & - & $2-$ & - & & 75 & - & 11 \\
\hline Mil & $\begin{array}{llll}1 & 5 & 11\end{array}$ & - & - & - & & - & - & $\overline{7}$ \\
\hline uthwark & 218 & 43 & - & 一 & & - & - & 29 \\
\hline Covent Garden & -73 & 16 & 一 & & & 84 & 1 & $\begin{array}{lll}2 & 2 & 6\end{array}$ \\
\hline 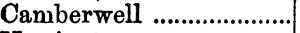 & 210 & - & - & 15 & 6 & 711 & - & $\begin{array}{lll}3 & 13 & 11\end{array}$ \\
\hline Newington ...... & -15 & 39 & - & -7 & 6 & 77 & - & $\begin{array}{lll}1 & 15 & 3\end{array}$ \\
\hline Plumstead & 118 & -1 & 106 & - & & - & - & 29 \\
\hline Rolls ................................... & -7 & 11 & - & - & & - & -5 & -8 \\
\hline Yeorge & -8 & -8 & - & 6 & 9 & $9-$ & - & 45 \\
\hline uthwark .... & 21 & 43 & - & - & & - & -1411 & $3 \quad-10$ \\
\hline Old Artillery Ground ... & -8 & 110 & - & - & & 84 & --6 & -195 \\
\hline Savo & -7 & 11 & - & - & & - & -5 & -8 \\
\hline Woo & 118 & 39 & 101 & - & 3 & - & $-5-$ & 3 \\
\hline Clap & -14 & $-\mathbf{3}$ & 27 & - & & & $-\quad-1$ & 14 \\
\hline 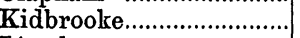 & 118 & - & - & 一 & & - & $-\quad-5$ & $\begin{array}{lll}1 & 18 & 11\end{array}$ \\
\hline $\operatorname{Lim}$ & -14 & - & - & - & & - & --6 & -148 \\
\hline Norton Folgate & -8 & 110 & - & - & & 84 & --6 & -19 \\
\hline 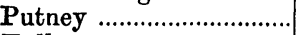 & -14 & -6 & 14. 7 & - & & 73 & --1 & 11610 \\
\hline & -9 & 410 & - & 一 & & 68 & $-\quad-11$ & $12-$ \\
\hline Mile End New Town .... & -8 & 210 & - & - & & 84 & $-\quad-8$ & 1 \\
\hline Wandsworth & -145 & -1 & 48 & - & & 61 & $-\quad-i$ & 15 \\
\hline Charlton & 1186 & - & - & - & & - & -8 & 119 \\
\hline & $\begin{array}{lllll}1 & 9 & 11\end{array}$ & 37 & - & -11 & 8 & $4-$ & --8 & 2910 \\
\hline & -89 & 110 & - & -9 & 7 & 84 & --10 & $\begin{array}{lll}1 & 9 & 4\end{array}$ \\
\hline 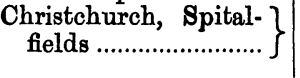 & -89 & 22 & - & - & & 84 & --6 & -199 \\
\hline
\end{tabular}


[Sept.

\begin{tabular}{|c|c|c|c|c|c|c|c|c|}
\hline \multirow[b]{2}{*}{ Name of Parish. } & \multicolumn{8}{|c|}{$\begin{array}{l}\text { Charges in respect of the Undermentioned Services, causing Differentiation of Rates } \\
\text { (per Cent. of Rateable Value). }\end{array}$} \\
\hline & $\begin{array}{l}\text { Out-door } \\
\text { Relief. }\end{array}$ & $\begin{array}{l}\text { Open Spaces } \\
\text { maintained } \\
\text { by Local } \\
\text { Authorities. }\end{array}$ & Burial. & $\begin{array}{r}\text { Bath } \\
\text { and } \\
\text { Wnshlior }\end{array}$ & ases. & Libraries. & $\begin{array}{c}\text { Other } \\
\text { Special } \\
\text { Services. }\end{array}$ & Total. \\
\hline Eltham ........... & $\begin{array}{rrr}£ & s . & d . \\
1 & 9 & 11\end{array}$ & s. $\quad d$. & s. $\quad d$. & $\mathscr{E} s$. & & s. $\quad d$. & $\begin{array}{lll}£ & s . & d . \\
- & - & 2\end{array}$ & $\begin{array}{ccc}£ & s . & d \\
1 & 10 & 1\end{array}$ \\
\hline Tooting Graveney & -145 & - & - & - & & - & $-\quad-1$ & $-14 \epsilon$ \\
\hline Horselydown & $\begin{array}{lll}2 & 1 & 8\end{array}$ & 43 & - & - & & - & $-\quad-7$ & 26 \\
\hline St. George, Southwark & -153 & 16 & - & - & & - & $-1-$ & -17 \\
\hline 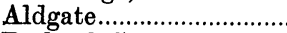 & -89 & 110 & - & - & & 84 & $-\quad-6$ & -19 \\
\hline Bethnal Green.................... & $\begin{array}{lll}1 & 2 & 4\end{array}$ & -5 & - & - & & - & -58 & 18 \\
\hline Shadwell ........................... & -14 & - & - & .- & & - & -194 & 113 \\
\hline Bermondsey & $\begin{array}{lll}2 & 1 & 8\end{array}$ & 29 & - & -3 & 1 & 78 & $-\quad-5$ & 215 \\
\hline 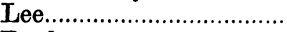 & $\begin{array}{lll}1 & 9 & 11\end{array}$ & -9 & 107 & - & & - & $-\quad-3$ & 21 \\
\hline Poplar .. & $\begin{array}{lll}2 & 2 & 3\end{array}$ & 31 & - & -3 & 8 & 84 & -5 & 33 \\
\hline Bow ......... & 22 & 36 & - & 25 & 5 & - & -1 & 4,12 \\
\hline 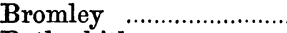 & 22 & $4-$ & - & - & & 84 & -11 & 215 \\
\hline Rotherhithe .......................... & $\begin{array}{lll}2 & 1 & 8\end{array}$ & - & 一 & -15 & 2 & 78 & --11 & 35 \\
\hline
\end{tabular}

The amount of increase stated as due to out-door relief is subject to the qualification that in some parishes and unions the portion of the establishment expenses due to out-door relief is included with the other establishment expenses, while in other parishes it is separately charged to out-door relief. This would cause a slight variation in the amounts entered to out-door relief, but does not materially affect the point to which this table is directed.

It will be seen that differentiation of rates due to those special causes ranges between $4 l .12 s .8 d$. per cent. in Bow, and $3 s .5 d$. per cent. in St. James, Westminster. In out-door relief St. James, Westminster, stands at is. $4 d$. per cent., and Camberwell at 2l. IOs. $5 d$. per cent.; for open spaces several parishes do not incur charges at all, while the highest-St. Luke's - incurs 5s. $3^{d}$. per cent.; for burial boards there are only fourteen parishes charged, the highest being Putney at $14 s .7 d$. per cent.; for baths and washhouses only twenty-eight parishes are charged, the highest being Bow, at $2 l$. $5 s .5 d$. per cent.; for public libraries thirty-eight parishes are charged, the highest being Clerkenwell, at IOs. $7 d$. per cent.; other special services range from nil in two parishes, up to Christchurch at $\mathrm{I} l .8 s .6 d$. per cent. These services account for a considerable proportion of the differentiation in rates.

I will now endeavour to estimate the effect of these special causes of differentiation of rates among the various parishes of the county. The following table summarises those which have already been given in detail, and shows the position occupied by 
each parish in the scale of differentiation, (1) before allowing for these ascertained causes of differentiation; and (2) after allowing for these ascertained causes.

It would be instructive, even with the limited information at command, to show in one table the several causes of differentiation which have been ascertained and put into terms of rating. It will be seen that in the same parish there may be causes of increased rating and causes of decreased rating, the net result being the amount of differentiation which does not come under the present systems of equalisation. These figures, imperfect as they must be characterised, are stated in the following table :-

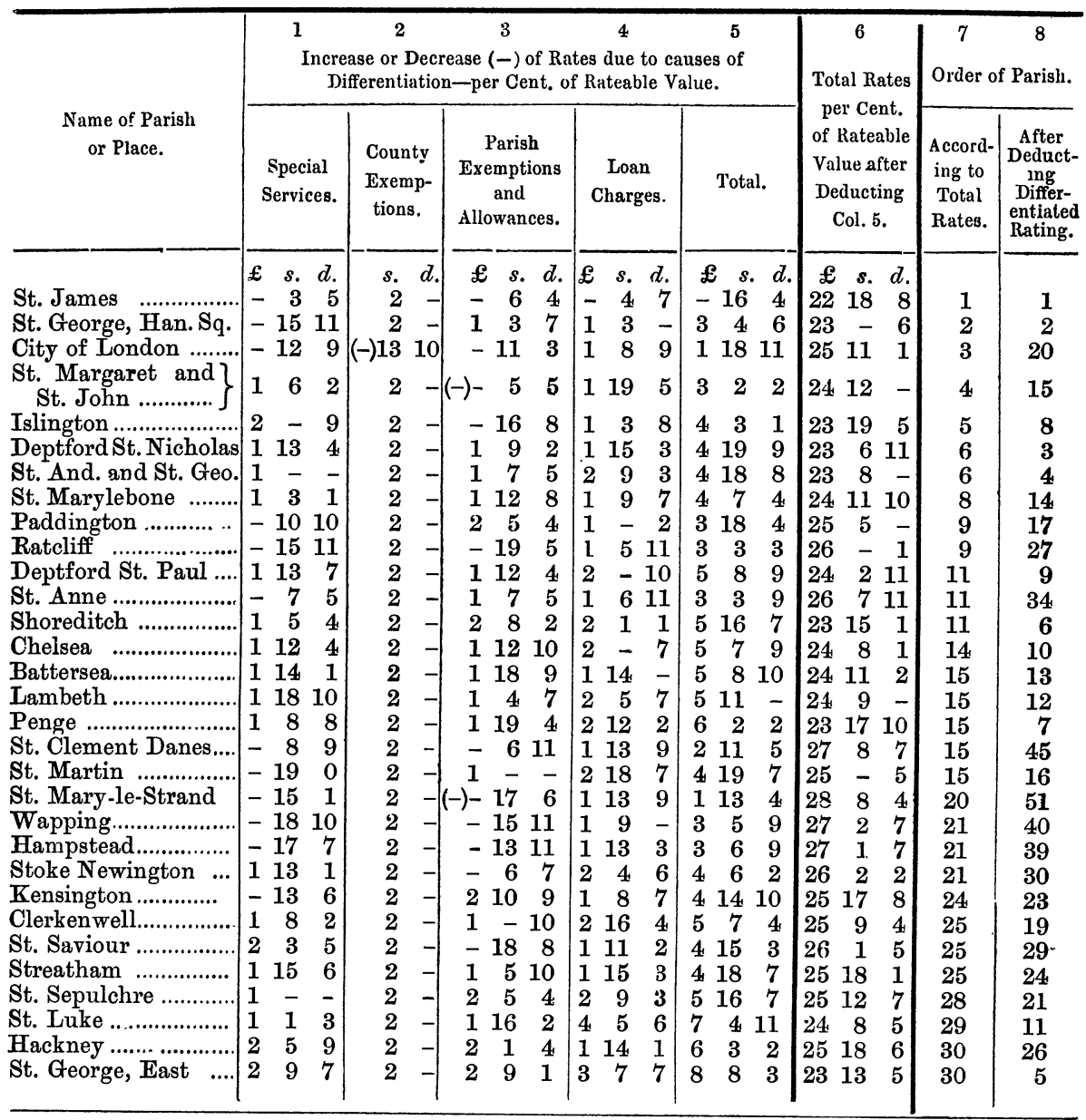

VOL. LXI. PART III.

$2 \mathrm{~L}$ 


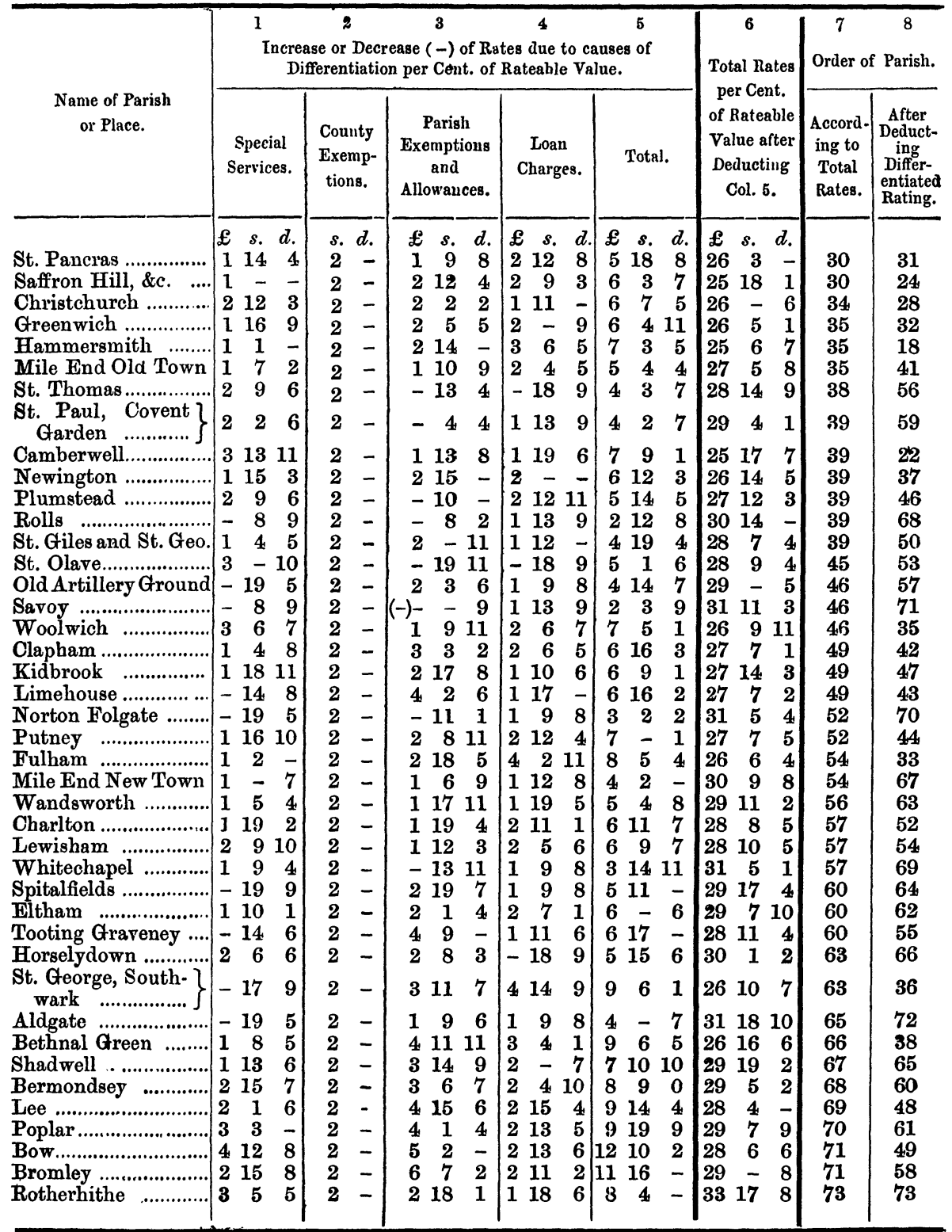


The result of this is to show that the range of differentiation, after accounting for these special causes, is still very considerable, namely, from 22l. I $8 s$. 8d. per cent. in St. James's, to $33 l .{ }_{1} 7 s .8 d$. per cent. in Rotherhithe.

This account of the differentiation of rates shows how important the subject is to the London ratepayer. And yet there is no means of affording the ratepayers any adequate information on the point. Considering the frequency of removals in London from one rating area to another, it is at least due to the ratepayer that he should be able to compare the rates of one parish with the rates of another. This at present he cannot do. Few reforms would be more beneficial than the adoption of a common form of demand note in every parish, and this could easily be accomplished by empowering the County Council to prescribe such a form as would meet the case. At present there are no two forms alike, and there is no single form which gives correct and adequate information as to local rates.

The incidence of rates levied on the rateable value of property is a subject of much controversy, and I can do no more than express my views of the matter. I believe, in the first place, that all local taxation should properly fall upon the owners of site value, because these owners benefit by local expenditure. We have seen that much of local expenditure falls upon allocated imperial taxation and upon local indirect taxation, and my conclusion is that owners are relieved, by this system, of a certain amount of taxation which should properly fall upon them. I believe, in the second place, that all direct taxation on rateable value of property does at present fall upon owners, but in the most unfair proportions. By reason of the absurd system of including: in rateable value the value of the buildings and deducting from the total a percentage for repairs, the falling of the rates on individual hereditaments is most unequal and burdensome. This question, however, opens up a subject which cannot now be dealt with, but it would have been unpardonable in an examination of a local taxaticn system such as that of London to have passed this question over in absolute silence.

It would not be proper to finish a paper on London local taxation, without referring to the cases of taxation in other hands than those of public authorities. They are as follows :-

(a) Appropriations from Imperial taxes-Voluntary Schools.

(b) Indirect taxation :-

Covent Garden Market.

Spitalfields Market.

Shadwell Market. 
(c) Direct taxation :-

Chelsea Waterworks Company.

East London Waterworks Company.

Grand Junction Waterworks Company.

Kent Waterworks Company.

Lambeth Waterworks Company.

New River Waterworks Company.

Southwark and Vauxhall Water Company.

West Middlesex Waterworks Company.

The amount appropriated to London ont of imperial taxation in respect of voluntary schools is made up of, first, the annual parliamentary grants based on average attendance and efficiency, these amounted in 1894-95 to $166,267 l$; secondly, the fee grants under the Elementary Education Act of 1891, based on the number of children between the ages of 3 and 15 in average attendance, these amounted in 1894-95 to about 83,900l.; thirdly, the Science and Art grants based on examination in specific subjects, these amounted in 1894-95 to $953 l$. These are grants in which all elementary schools (i.e., board as well as voluntary) participate alike, the total amount paid to voluntary schools in London in 1894-95 being about 25 I, I $20 l$.

By the Voluntary Schools Act of 1897, an additional grant is made to voluntary schools amounting to 5 s. per scholar in average attendance. The total grant estimated for England and Wales for the year is 616,000l., and assuming that London receives $5 \mathrm{~s}$. in respect of each scholar in average attendance (1894-95), its share might be estimated at about $44,000 l$.

The latest information about the tolls levied from the markets in private hands is contained in the Markets Commission Report of 1891 (vol. xiii, part 1, p. 26). The amount of taxation is as follows:-

\begin{tabular}{|c|c|c|}
\hline & $£$ & \\
\hline 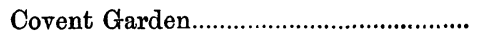 & I 3,000 & \\
\hline (1) & 4,857 & \\
\hline 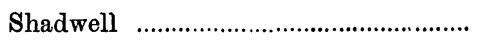 & 400 & \\
\hline
\end{tabular}

The amount of taxation levied by the water companies is not to be obtained from the published accounts of the companies, because the total revenue of each of the companies, as stated in the accounts, includes the amount received from sale of water by meter, and from extra charges. From a return prepared for the Council of the property liable to be rated for water purposes within the 
areas of the eight companies, it appears that the total amount raised by rates in London by each of the companies may be estimated as follows :-

\begin{tabular}{|c|c|c|c|c|c|}
\hline Company. & Amount. & $\begin{array}{c}\text { Rates per } \mathscr{E} \\
\text { of } \\
\text { Rateable Value. }\end{array}$ & \multicolumn{3}{|c|}{$\begin{array}{l}\text { Rate per Ceut. } \\
\text { of } \\
\text { Rateable Value. }\end{array}$} \\
\hline Chelsea & $\begin{array}{c}£ \\
99,204\end{array}$ & $\begin{array}{c}d . \\
8 \cdot 6\end{array}$ & $\begin{array}{l}£ \\
3\end{array}$ & $\begin{array}{l}s . \\
11\end{array}$ & $\begin{array}{l}d . \\
7\end{array}$ \\
\hline East London ....................... & 133,603 & $12^{\circ} \circ$ & 5 & - & - \\
\hline Grand Junction..................... & 103,384 & $8 \cdot 0$ & 3 & 6 & 5 \\
\hline Kent & 78,919 & 12.7 & 5 & 5 & 9 \\
\hline 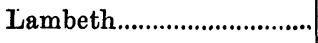 & 154,767 & 154 & 6 & 8 & 2 \\
\hline 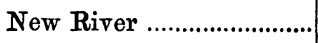 & 343,046 & $8 \cdot 4$ & 3 & 10 & 1 \\
\hline Southwark and Vauxball & 164,148 & $12 \cdot 0$ & 5 & - & - \\
\hline West Middlesex.................... & 143,830 & $8 \cdot 0$ & 3 & 6 & 7 \\
\hline Total …................ & $1,220,901$ & $9^{\cdot 8}$ & 4 & 1 & 10 \\
\hline
\end{tabular}

These rates are not raised equally over any established rating area. They vary, not only in different parts of the county, but in different parts of the same parish. The highest rated parish for water is Penge, where the charge is equal to an average rate of Is. $3.8 d$. in the $f$, and the lowest is the city of London, where the charge is equal to an average rate of $7.5 d$. in the $£$.

The present anomalous position in which the ratepayers of London are placed in respect of the rating for water supply is not confined to the one cause of differences in charge, serious as these differences are, but also to the creation of different rating areas marked off from the rest of the county on the one hand by an arbitrary line fixed for the convenience of the companies and, on the other hand, extended beyond the county boundary. The principle of all valuation for rating is that higher valuations shall assist the lower valuations, and to such an extent is this recognised in London, that the common poor fund and the equalisation fund were established to extend the principle to the case of local charges, which are made thereby a common charge on the whole county, as in the case of services administered by central authorities. The county area, therefore, has become by this plan, which is peculiar to London, an area in which the incidence of taxation 
is specially marked off from that obtaining in neighbouring counties, and every extension of the area of taxation beyond the county boundary, as in the case of water, constitutes a departure from the principle of common rating for common purposes, which can only be justified by very exceptional circumstances.

I have, in conclusion, to offer an apology for using figures which I have to a great extent already used in giving evidence to the Royal Commission on Local Taxation; but my apology must be accompanied by an explanation : there are no other figures. It might be expected that the local taxation accounts published by the Local Government Board would at least concern itself with taxation. But this seems to be the very last object in view, at least it is not an object which is attained. It is not possible to ascertain the local taxation of a single taxing unit in the kingdom. I do not think it would be going too far to say that the real taxation account of any one of the three kingdoms is unascertainable.

Certainly that of the capital of the empire is not ascertainable. The statement published by the Local Government Board of metropolitan taxation does not show receipts and expenditure as they affect local taxation in respect of a taxing area. Thus, the principle on which receipts from other local authorities and payments to other local authorities are dealt with, is that the authority actually making the payment for any service is credited with the whole amount paid, even though part of it is recovered from another authority for whom the service is rendered and upon whose local taxation the charge actually falls. For instance, the London County Council pays interest on behalf of Middlesex, and recovers it from the Middlesex County Council. The charge is, therefore, defrayed out of the local taxation of Middlesex; the local taxation returns, however, show it to be paid out of the local taxation of London.

Again, the local taxation returns ignore amounts set aside for repayment of debt through the council's consolidated loans fund, although these amounts are actually provided out of local taxation. The consequence is that every year the expenditure of the London County Council is shown at an amount much below the receipts, while in 1929 , when the $3 \frac{1}{2}$ per cent. metropolitan consolidated stock is redeemable, the council will be credited with a payment of some millions in excess of its receipts.

Another point is that the statistics relating to poor law authorities only relate to that monstrosity of statistics, the registration county, and therefore in the case of London exclude those for Penge.

Several adjustments are necessary. The Thames Conservancy 
(lower navigation) account is not included in the summary given in the local taxation returns, although it levies taxes on London. The amounts raised for equalisation purposes should be added to the county rates, and deducted from the parish rates. Receipts from imperial taxation, from indirect taxation, from municipal property, and from other sources should be separately stated. 


\section{A P PEN D IX.}

A.-Expenditure by Local Authorities in respect of each Parish in the Year 1895-96,

Rateable

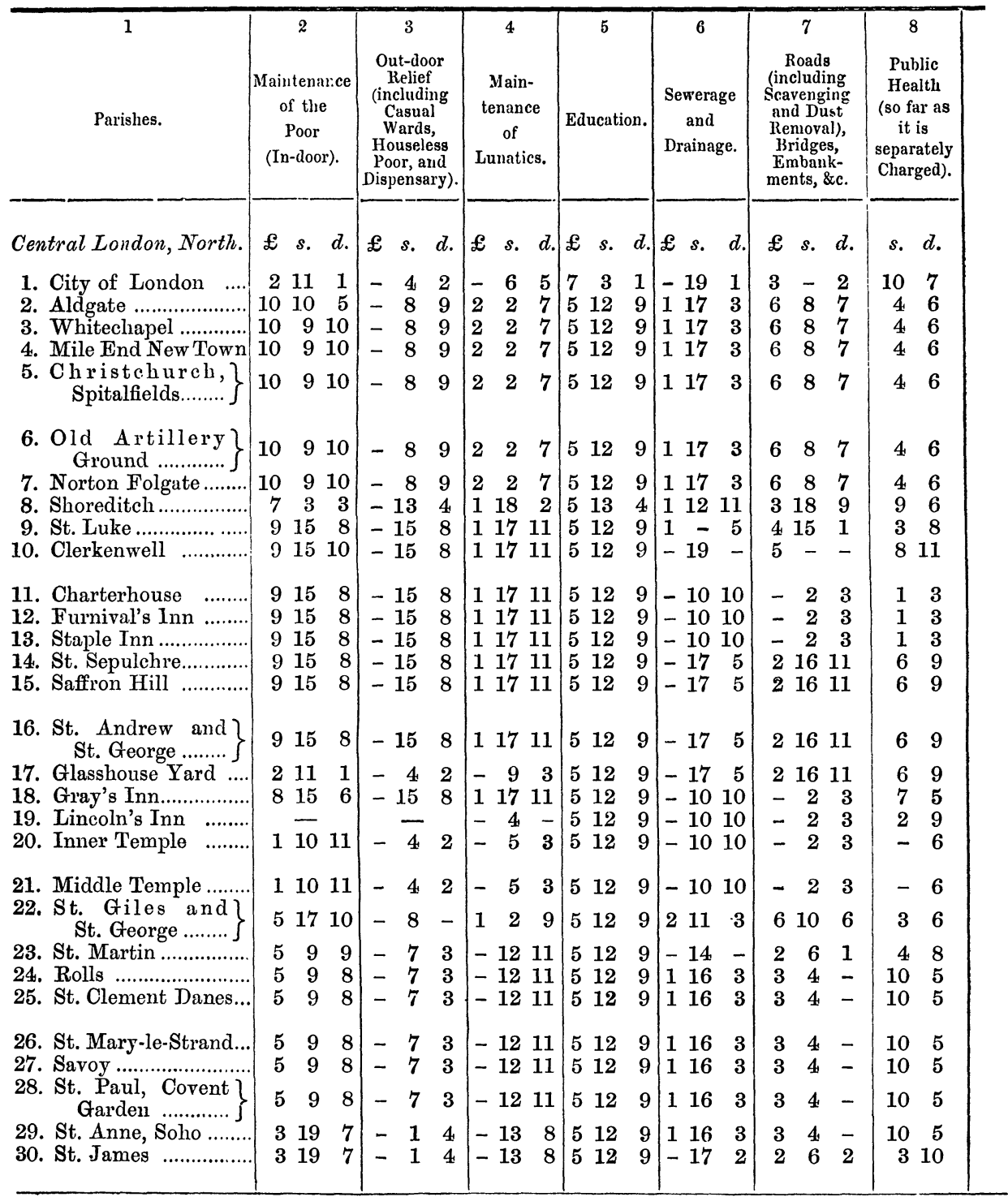




\section{A P P E N D IX.}

analysed according to the principal heads of Charge; reduced to Percentages of Value.

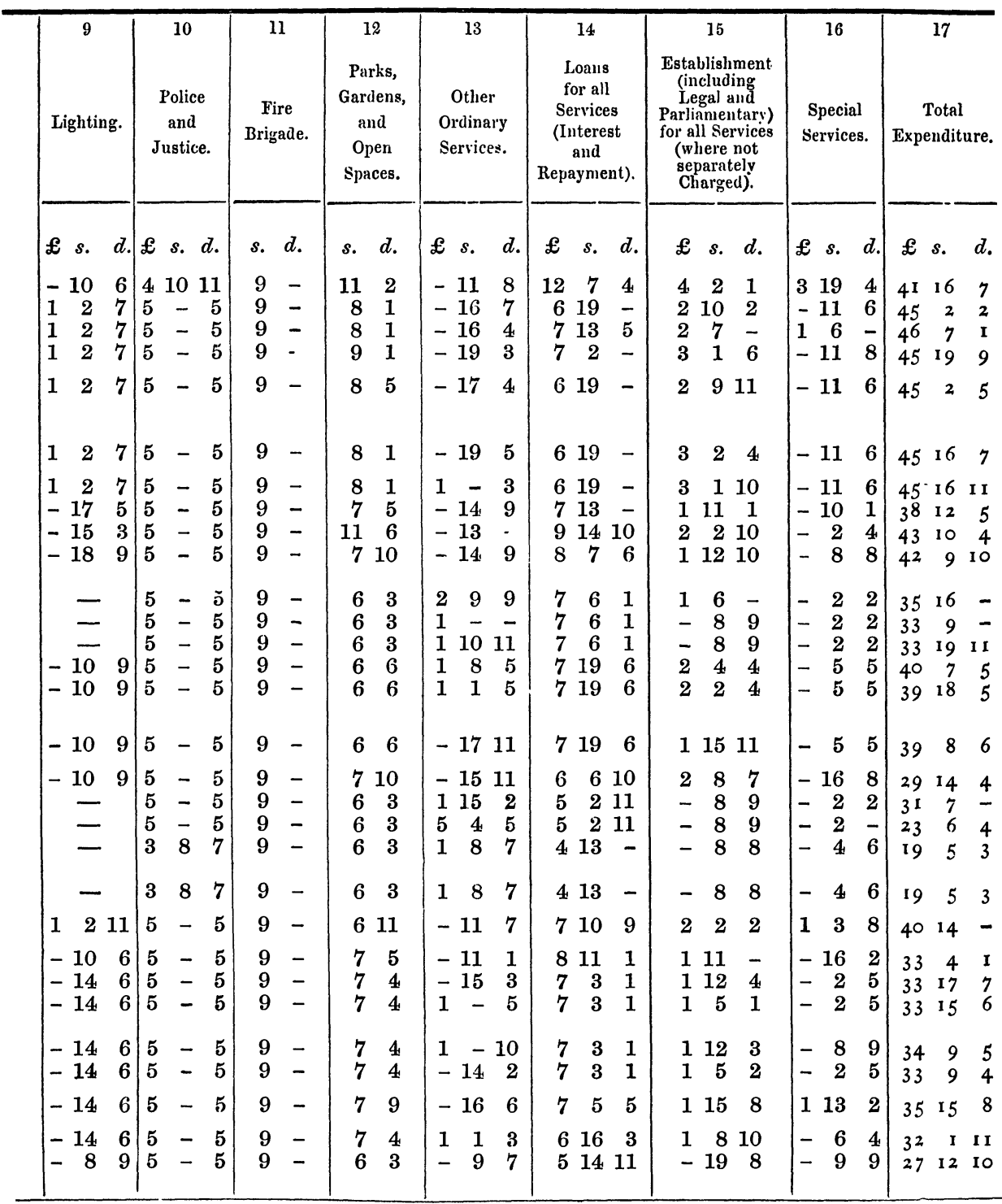


A-Contd. Expenditure by Local Authorities in respect of each Parish in 1895-96, analysed

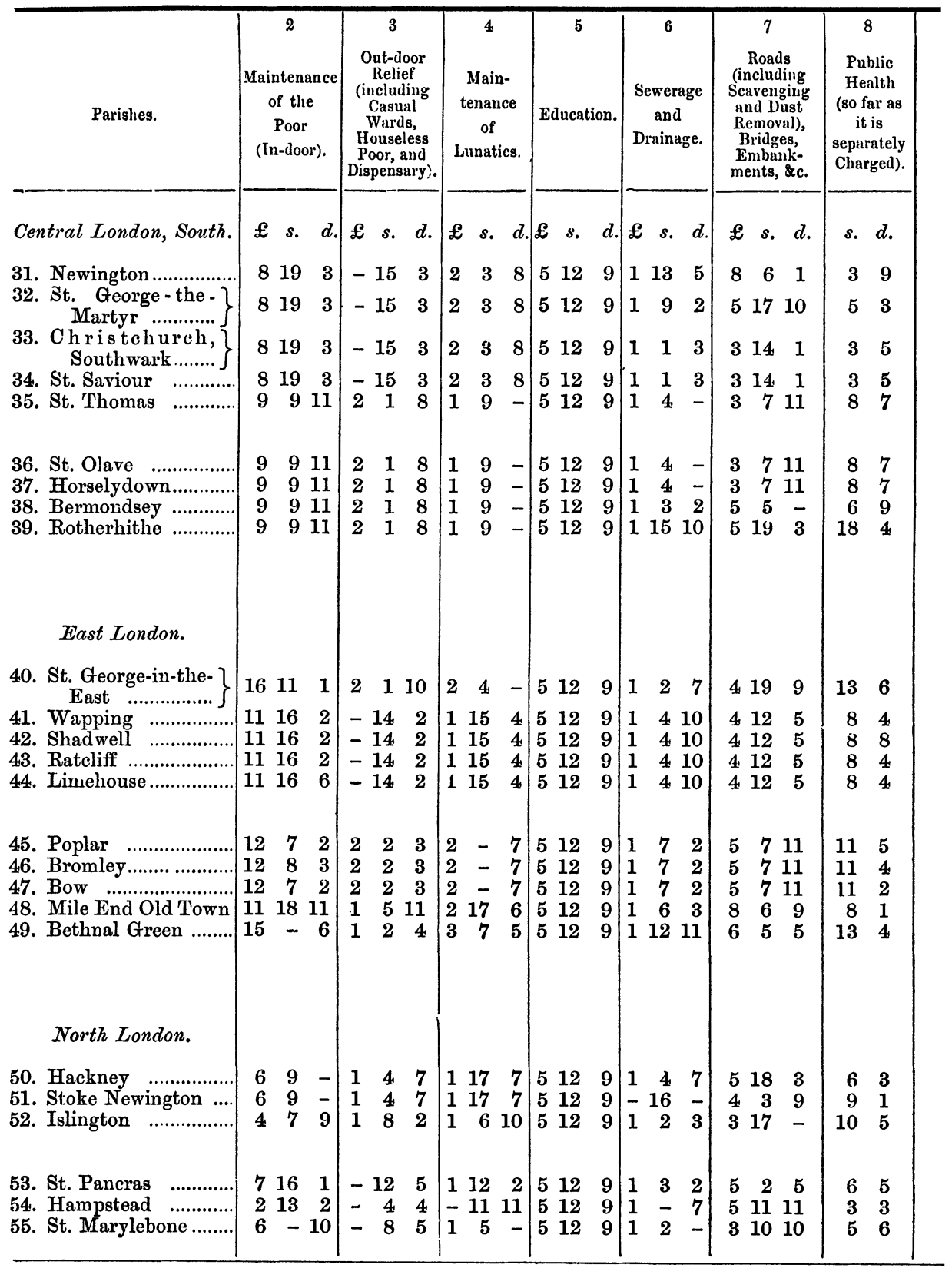


according to the principal heads of Charge; reduced to Percentages of Rateable Value.

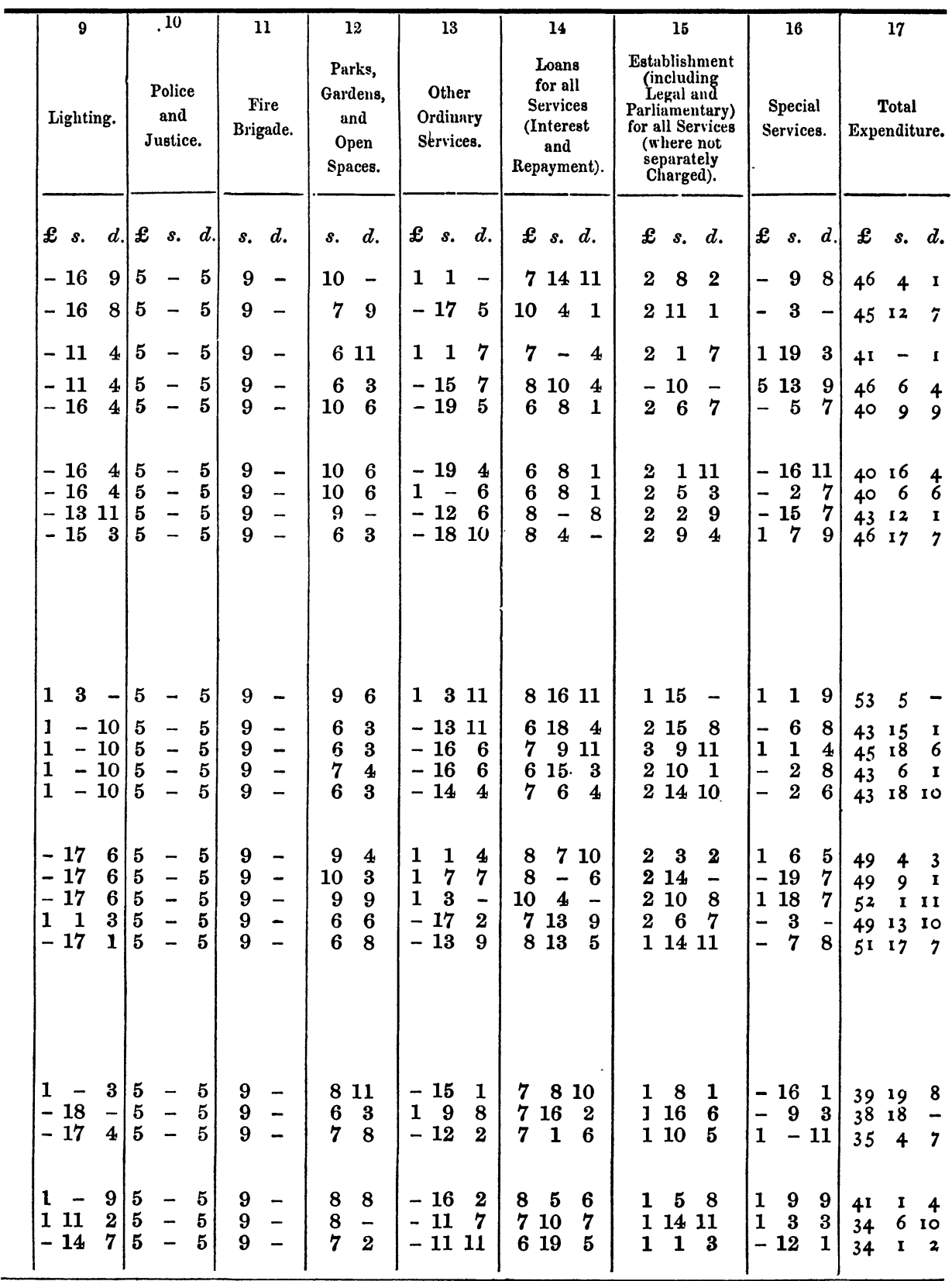


A-Contd. Expenditure by Local Authorities in respect of each Parish in 1895-96, analysed

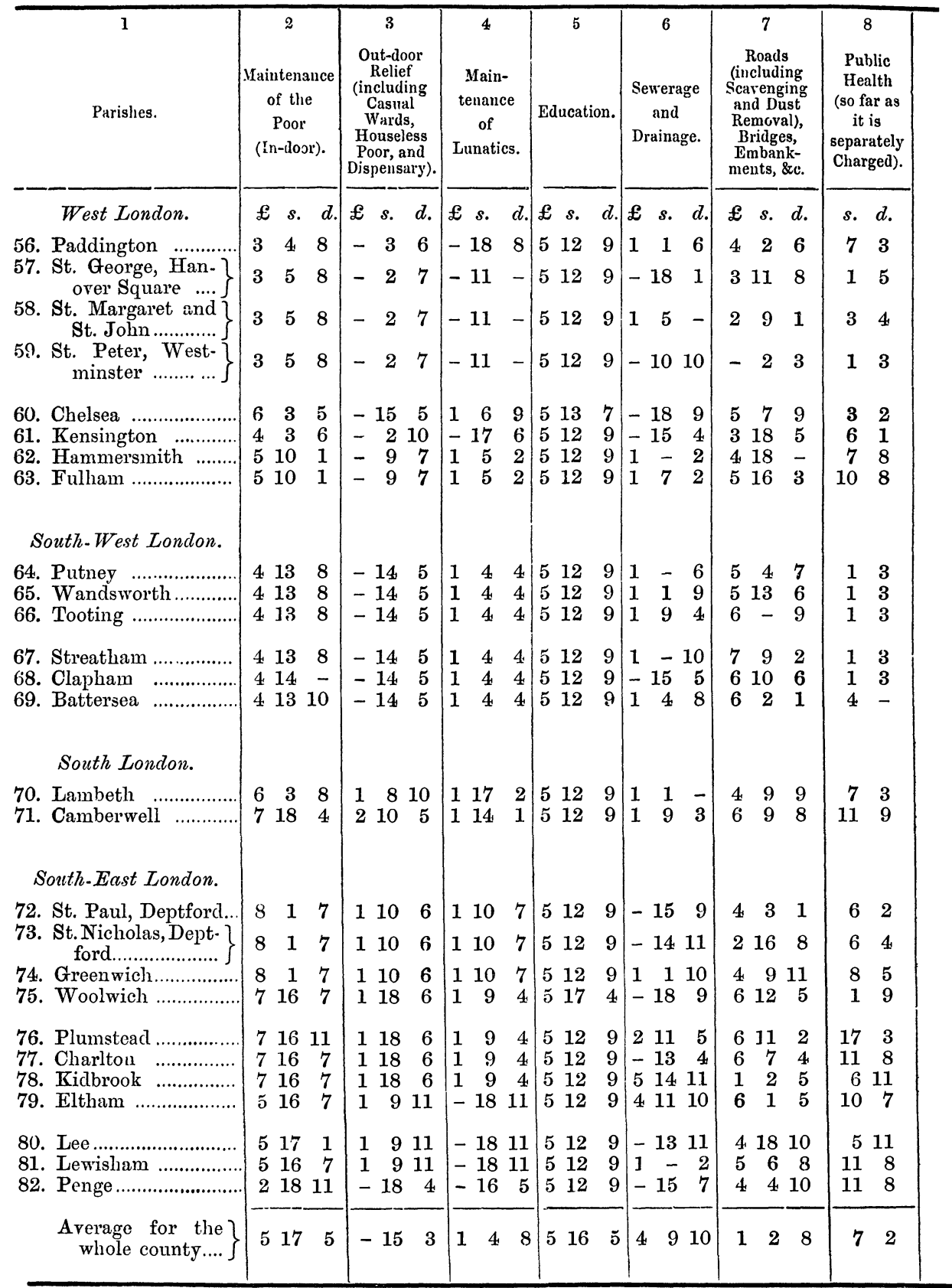


according to the principal heads of Charge; reduced to Percentages of Rateable Value.

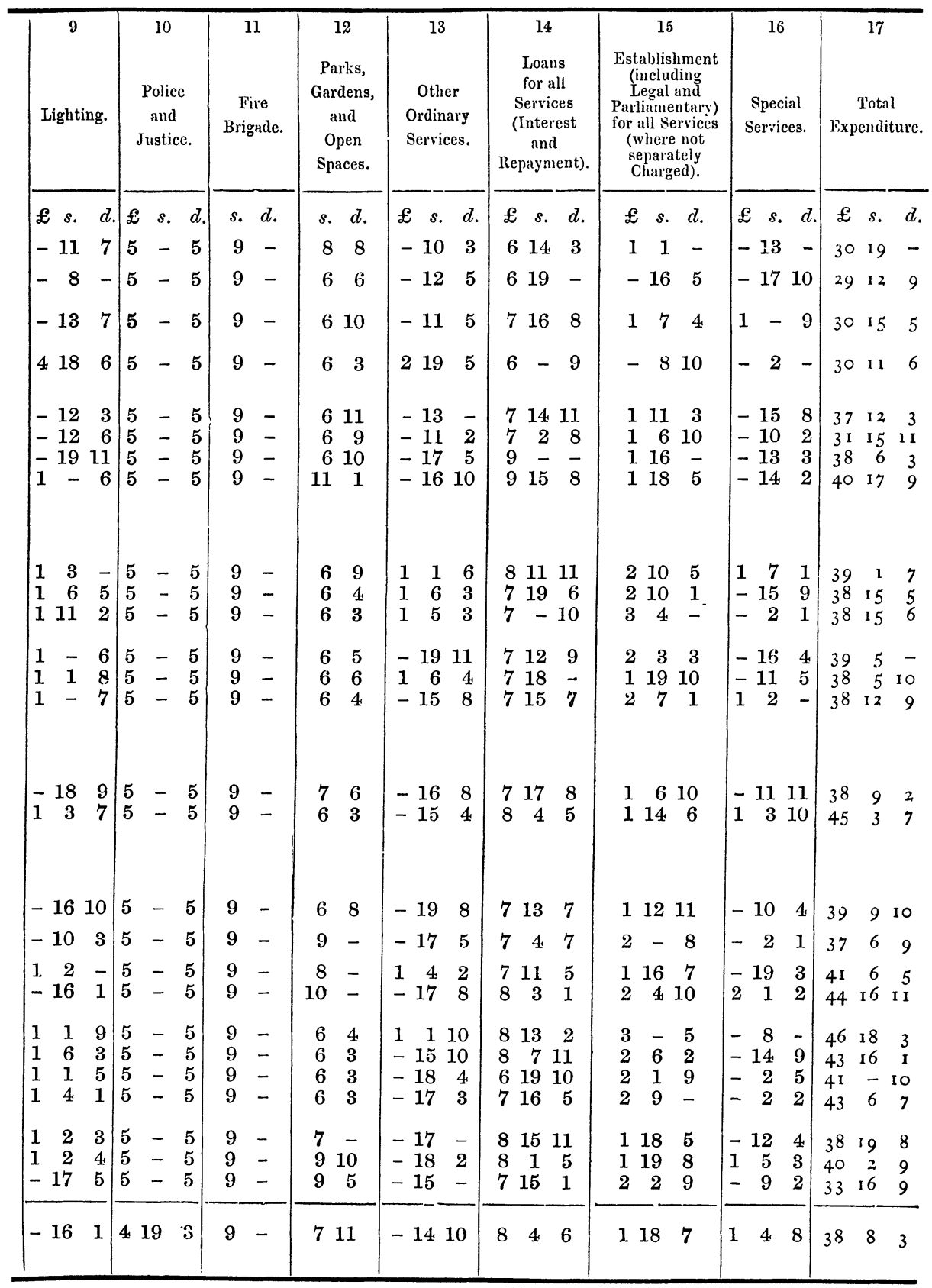


B.-Expenditure brought forward, Deductions and Additions determining the Charge on Alterations in the Charge caused by the Operation of the County Grants, the Loss by Empty Properties, \&\&.; Reduced to Percentages of Rateable Value.

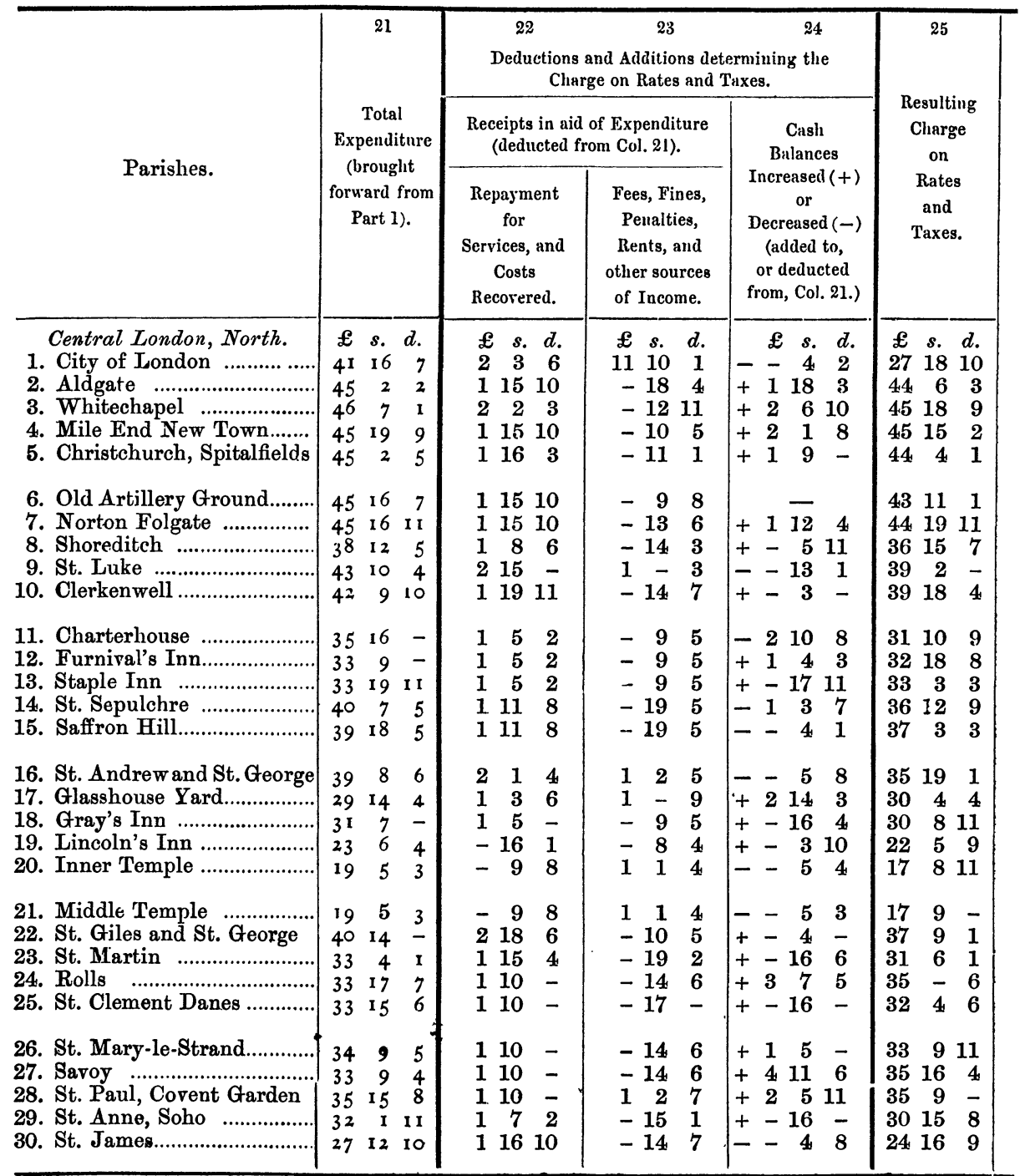


Rates and Taxes, and the Resulting Charge on Rates and Taxes after taking account of Equalisation Fund and the Common Poor Fund, and by the Amount Charged in respect of

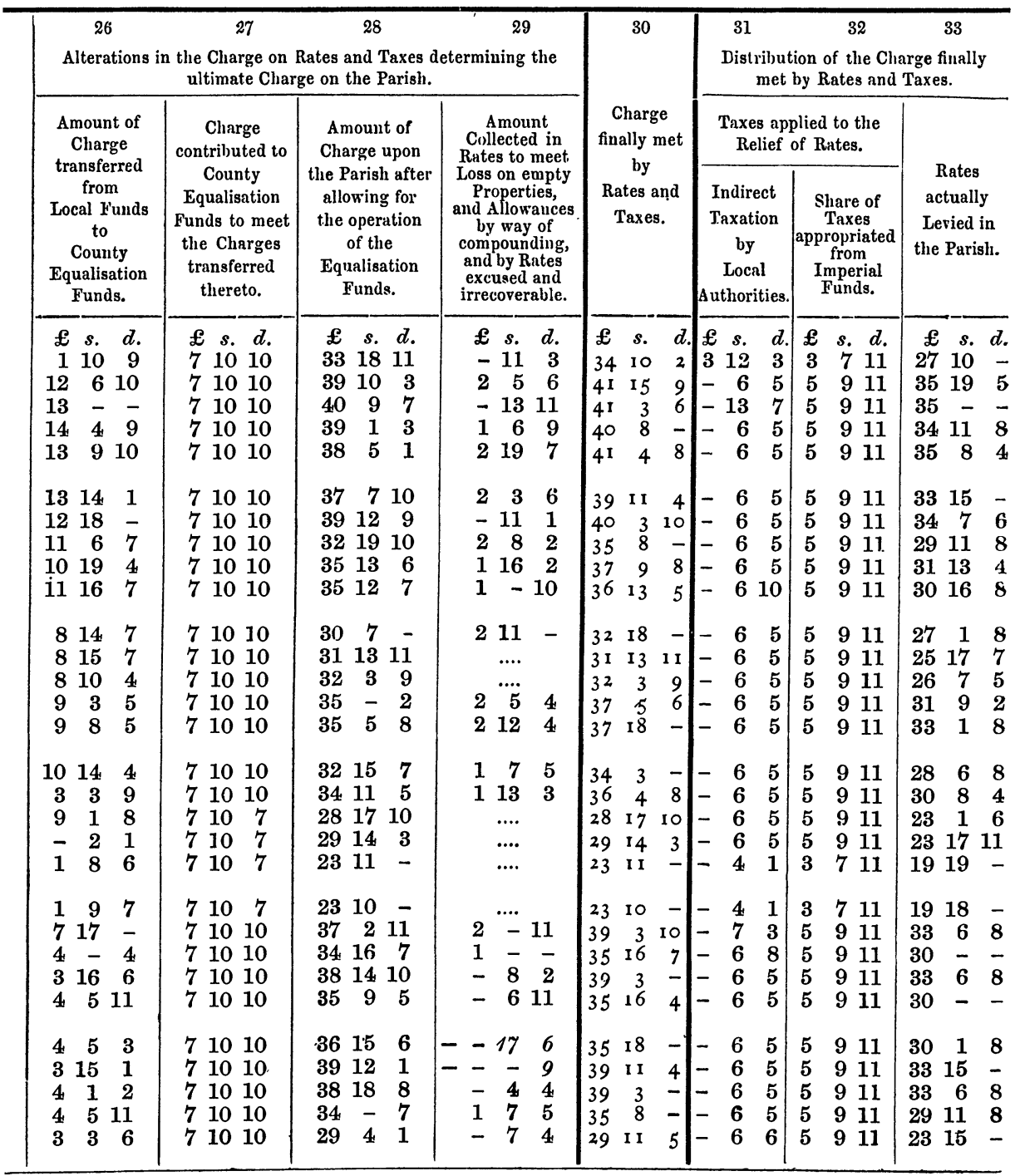


B. Contd.-Expenditure brought forward, \&c.,

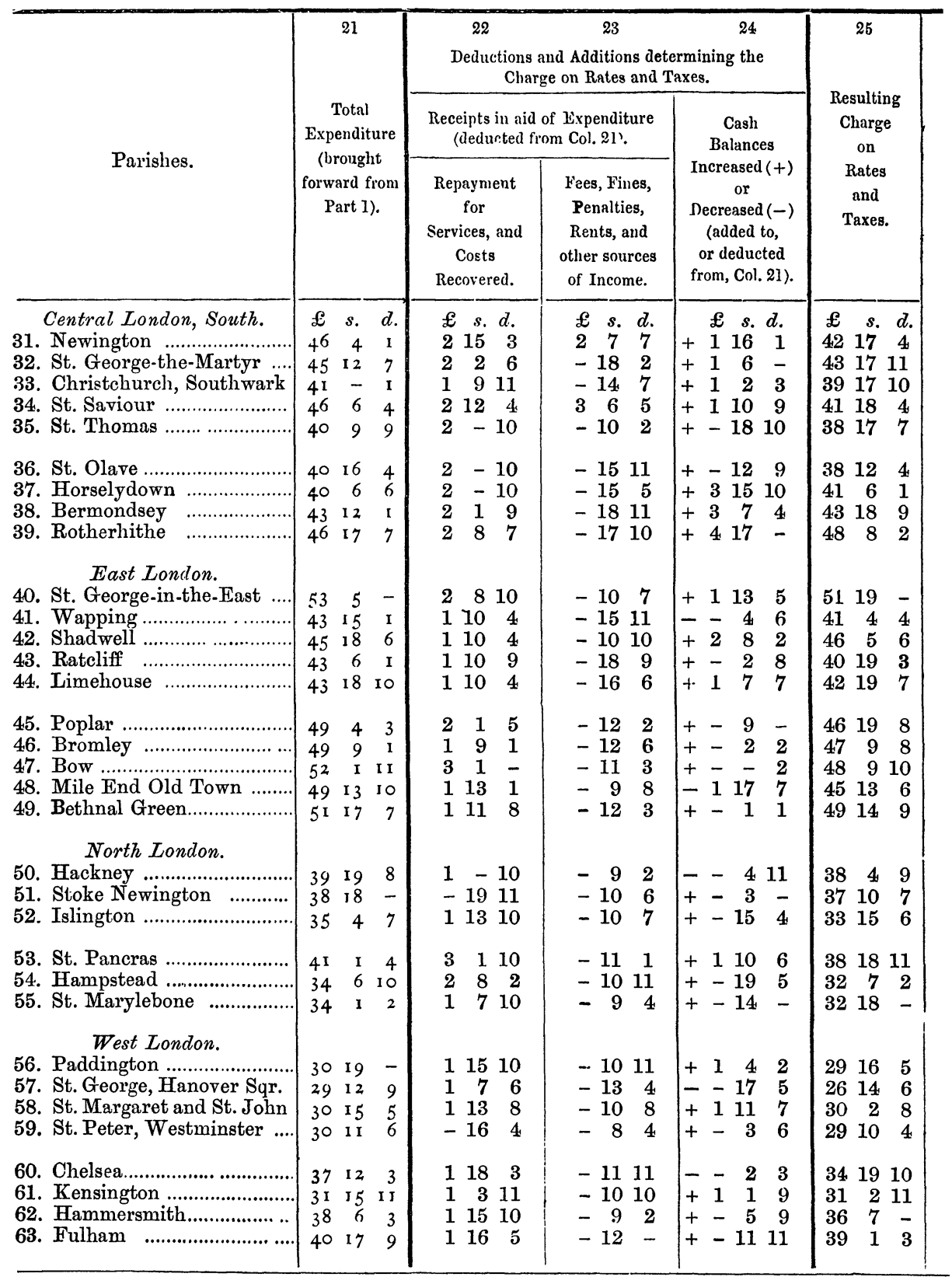


Reduced to Percentages of Rateable Value.

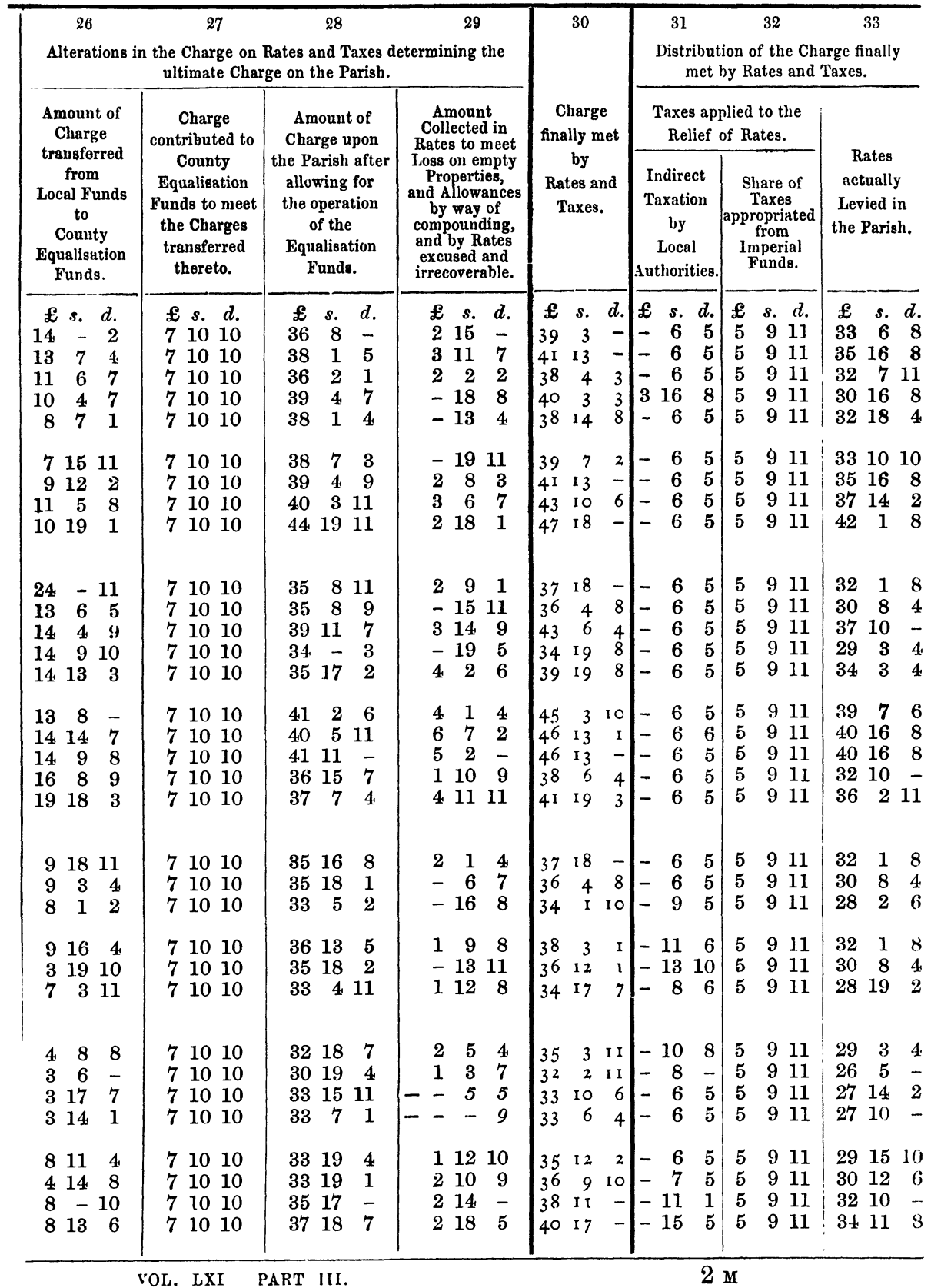


[Sept.

B. Contd.-Expenditure brought forward, \&c.,

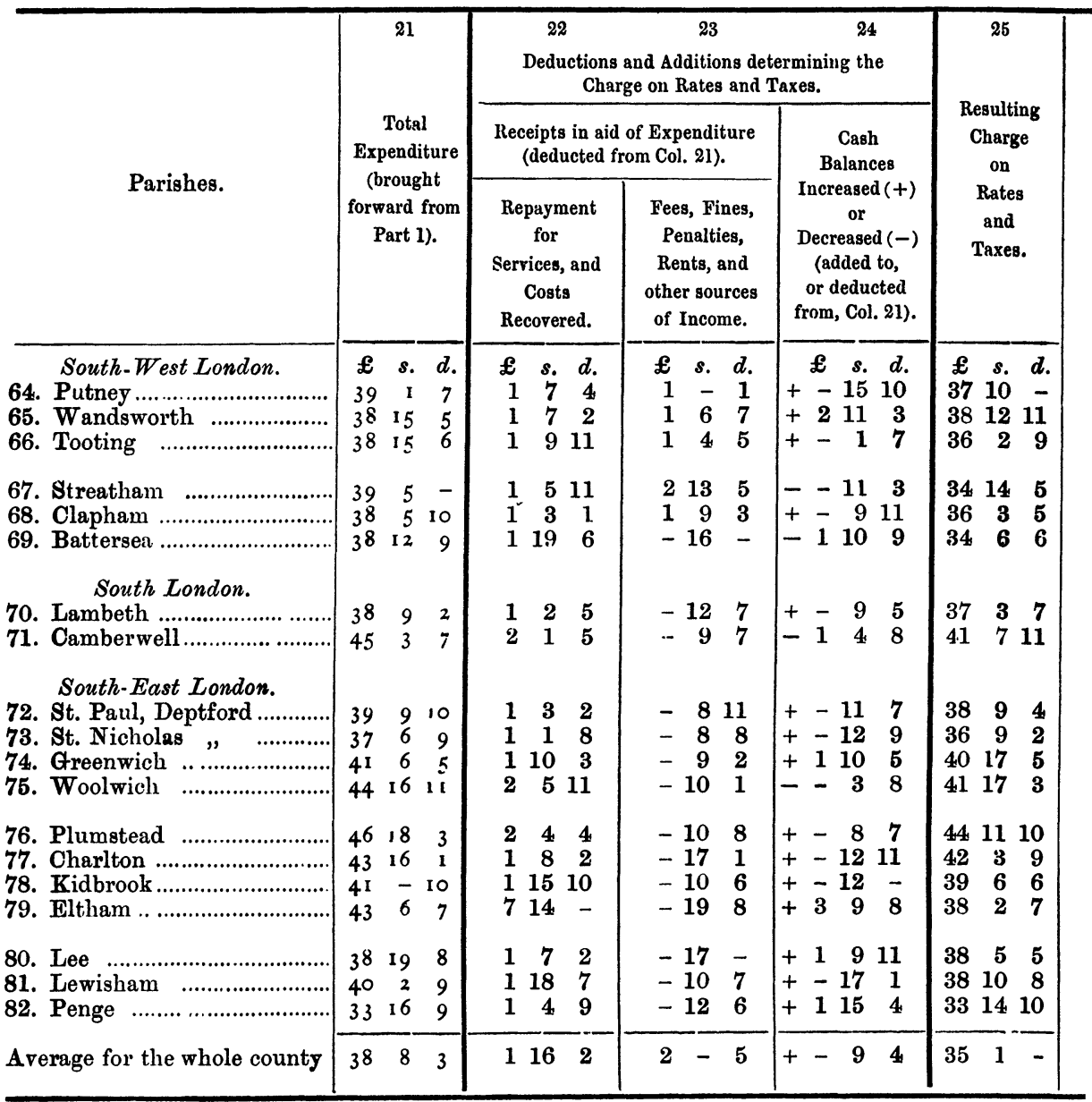


Reduced to Percentages of Rateable Value.

\begin{tabular}{|c|c|c|c|c|c|c|c|c|c|}
\hline \multirow{2}{*}{\multicolumn{4}{|c|}{ 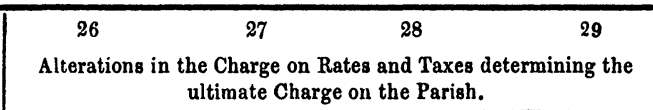 }} & \multirow{2}{*}{\multicolumn{2}{|c|}{30}} & \multirow{2}{*}{\multicolumn{4}{|c|}{$\begin{array}{c}31 \\
\text { Distribution of the Charge finally } \\
\text { met by Rates and Taxes. }\end{array}$}} \\
\hline & & & & & & & & & \\
\hline \multirow{2}{*}{$\begin{array}{c}\text { Amount of } \\
\text { जlarge } \\
\text { transferred } \\
\text { from } \\
\text { Local Funds } \\
\text { to } \\
\text { County } \\
\text { Equalisation } \\
\text { Funds. }\end{array}$} & \multirow{2}{*}{$\begin{array}{l}\text { Charge } \\
\text { contributed to } \\
\text { County } \\
\text { Equalisation } \\
\text { Funds to meet } \\
\text { the Charges } \\
\text { transferred } \\
\text { thereto. }\end{array}$} & \multirow{2}{*}{$\begin{array}{l}\text { Amount of } \\
\text { Charge upon } \\
\text { the Parish after } \\
\text { allowing for } \\
\text { the operation } \\
\text { of the } \\
\text { Equalisation } \\
\text { Funds. }\end{array}$} & \multirow{2}{*}{$\begin{array}{l}\text { Amount } \\
\text { Collected in } \\
\text { Rates to meet } \\
\text { Loss on empty } \\
\text { Properties, } \\
\text { and Allowances } \\
\text { by way of } \\
\text { compounding, } \\
\text { and by Rates } \\
\text { excused and } \\
\text { irrecoverable. }\end{array}$} & \multirow{2}{*}{\multicolumn{2}{|c|}{$\begin{array}{c}\text { Charge } \\
\text { finally met } \\
\text { by } \\
\text { Rates and } \\
\text { Taxes. }\end{array}$}} & \multicolumn{2}{|c|}{$\begin{array}{l}\text { Taxes applied to the } \\
\text { Relief of Rates. }\end{array}$} & \multirow{2}{*}{\multicolumn{2}{|c|}{$\begin{array}{c}\text { Rates } \\
\text { actually } \\
\text { Levied in } \\
\text { the Parish. }\end{array}$}} \\
\hline & & & & & & $\begin{array}{c}\text { Indirect } \\
\text { Taxation } \\
\text { by } \\
\text { Local } \\
\text { Authorities. }\end{array}$ & $\begin{array}{c}\text { Share of } \\
\text { Taxes } \\
\text { appropriated } \\
\text { from } \\
\text { Imperial } \\
\text { Funds. }\end{array}$ & & \\
\hline $\begin{array}{llr}£ & s . & d . \\
6 & 13 & 5 \\
6 & 16 & 11 \\
6 & 17 & 11\end{array}$ & $\begin{array}{ccc}£ & s . & d . \\
7 & 10 & 10 \\
7 & 10 & 10 \\
7 & 10 & 10\end{array}$ & $\begin{array}{rrr}£ & s . & d . \\
38 & 7 & 5 \\
39 & 6 & 10 \\
36 & 15 & 8\end{array}$ & $\begin{array}{rrr}£ & s . & d . \\
2 & 8 & 11 \\
1 & 17 & 11 \\
4 & 9 & -\end{array}$ & $\begin{array}{cc}£ & s . \\
40 & 16 \\
4 \mathrm{I} & 4 \\
4 \mathrm{I} & 4\end{array}$ & & $\begin{array}{lrr}£ & s . & d . \\
- & 18 & 11 \\
- & 19 & - \\
- & 6 & 5\end{array}$ & $\begin{array}{rrr}f & s . & d . \\
5 & 9 & 11 \\
5 & 9 & 11 \\
5 & 9 & 11\end{array}$ & $\begin{array}{ccc} \pm & s . & d \\
34 & 7 & \\
34 & 15 & 1 \\
35 & 8 & \end{array}$ & \\
\hline $\begin{array}{lll}6 & 14 & 5 \\
6 & 16 & 3 \\
7 & 15 & 11\end{array}$ & $\begin{array}{lll}7 & 10 & 10 \\
7 & 10 & 10 \\
7 & 10 & 10\end{array}$ & $\begin{array}{rrr}35 & 10 & 10 \\
36 & 18 & - \\
34 & 1 & 5\end{array}$ & $\begin{array}{rrr}1 & 5 & 10 \\
3 & 3 & 2 \\
1 & 18 & 9\end{array}$ & $\begin{array}{rr}36 & 16 \\
40 & 1 \\
36 & -\end{array}$ & & 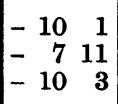 & $\begin{array}{lll}5 & 9 & 11 \\
5 & 9 & 11 \\
5 & 9 & 11\end{array}$ & $\begin{array}{rr}30 & 16 \\
34 & 3 \\
30 & -\end{array}$ & \\
\hline $\begin{array}{rrr}9 & 18 & 10 \\
11 & 3 & 3\end{array}$ & $\begin{array}{lll}7 & 10 & 10 \\
7 & 10 & 10\end{array}$ & $\begin{array}{lll}34 & 15 & 7 \\
37 & 15 & 6\end{array}$ & $\begin{array}{rrr}1 & 4 & 7 \\
1 & 13 & 8\end{array}$ & $\begin{array}{ll}36 & - \\
39 & 9\end{array}$ & & $\begin{array}{ll}-10 & 3 \\
-12 & 7\end{array} \mid$ & $\begin{array}{lll}5 & 9 & 11 \\
5 & 9 & 11\end{array}$ & $\begin{array}{ll}30 & \overline{6} \\
33 & 6\end{array}$ & \\
\hline $\begin{array}{rrr}11 & 15 & 10 \\
11 & 6 & 2 \\
12 & 2 & 2 \\
10 & 14 & 10\end{array}$ & $\begin{array}{lll}7 & 10 & 10 \\
7 & 10 & 10 \\
7 & 10 & 10 \\
7 & 10 & 10\end{array}$ & $\begin{array}{rrr}34 & 4 & 4 \\
32 & 13 & 10 \\
36 & 6 & 1 \\
38 & 13 & 3\end{array}$ & $\begin{array}{rrr}1 & 12 & 4 \\
1 & 9 & 2 \\
2 & 5 & 5 \\
1 & 9 & 11\end{array}$ & $\begin{array}{rr}35 & 16 \\
34 & 3 \\
38 & 11 \\
40 & 3\end{array}$ & & $\begin{array}{rr}-15 & 1 \\
-\quad 6 & 5 \\
-11 & 7 \\
-18 & 3\end{array}$ & $\begin{array}{ll}9 & 11 \\
9 & 11 \\
9 & 11 \\
9 & 11\end{array}$ & $\begin{array}{rr}29 & 11 \\
28 & 6 \\
32 & 10 \\
33 & 15\end{array}$ & $\begin{array}{l}8 \\
8 \\
- \\
-\end{array}$ \\
\hline $\begin{array}{rrr}13 & 3 & 8 \\
9 & 18 & 4 \\
9 & 15 & 4 \\
6 & 10 & 1\end{array}$ & $\begin{array}{lll}7 & 10 & 10 \\
7 & 10 & 10 \\
7 & 10 & 10 \\
7 & 10 & 10\end{array}$ & $\begin{array}{rrr}38 & 19 & - \\
39 & 16 & 3 \\
37 & 2 & - \\
39 & 3 & 4\end{array}$ & $\begin{array}{rrr}- & 10 & - \\
1 & 19 & 4 \\
2 & 17 & 8 \\
2 & 1 & 4\end{array}$ & $\begin{array}{rr}39 & 9 \\
41 & 15 \\
39 & 19 \\
41 & 4\end{array}$ & $\begin{array}{l}- \\
7 \\
8 \\
8\end{array}$ & $\begin{array}{rrr}- & 12 & 5 \\
1 & 5 & 8 \\
- & 6 & 5 \\
- & 6 & 5\end{array}$ & $\begin{array}{ll}9 & 11 \\
9 & 11 \\
9 & 11 \\
9 & 11\end{array}$ & $\begin{array}{ll}33 & 6 \\
35 & - \\
34 & 3 \\
35 & 8\end{array}$ & $\begin{array}{l}8 \\
4 \\
4\end{array}$ \\
\hline $\begin{array}{rr}6 & 8 \\
6 & 13 \\
3 & 19\end{array}$ & $\begin{array}{rrr}7 & 10 & 10 \\
7 & 10 & 10 \\
4 & 1 & 6\end{array}$ & $\begin{array}{rrr}39 & 8 & 2 \\
39 & 8 & 1 \\
33 & 17 & -\end{array}$ & $\begin{array}{lll}4 & 15 & 6 \\
1 & 12 & 3 \\
1 & 19 & 4\end{array}$ & $\begin{array}{ll}44 & 3 \\
41 & - \\
35 & 16\end{array}$ & $\begin{array}{l}8 \\
4 \\
4\end{array}$ & $\left|\begin{array}{rr}-15 & 5 \\
-10 & 5 \\
-6 & 5\end{array}\right|$ & $\begin{array}{lll}5 & 9 & 11 \\
5 & 9 & 11 \\
5 & 9 & 11\end{array}$ & $\begin{array}{ll}37 & 18 \\
35 & - \\
30 & -\end{array}$ & \\
\hline 710 & 7105 & $351-$ & $\begin{array}{lll}2 & 1 & 4\end{array}$ & $37 \quad 2$ & & $\begin{array}{ll}-17 & 5\end{array}$ & $4 \quad 9$ & $31-$ & \\
\hline
\end{tabular}




\section{Discussion on Mr. Gomme's Paper.}

The Chairman (Mr. A. E. Bateman, C.M.G.) said they were all much indebted to $\mathrm{Mr}$. Gomme for his valuable and comprehensive paper. He was sure everyone would agree with him that the paper was full of valuable statistics, and that it would be read with interest by those who had not been able to attend the meeting. It was the first paper that had been read at the Society dealing with the financial aspect of this great county of London, ta which most of those present belonged, and he hoped it would not be the last paper that Mr. Gomme would favaur them with. He (the Chairman) was not an expert on the subject, but he was sure there were several present who could contribpte to the discussion of the controversial points dealt with in the paper.

Mr. C. S. Loch said the paper contained a fund of information which was inaccessible elsewhere. The question that interested him was the problem of differentiation. By that he understood Mr. Gomme to mean all those causes which brought about a variation of the rate as between district and district. Differentiation was of two kinds. In one class of cases it was produced by the intervention of statutes in consequence of which the proceeds of Exchequer grants were received by the various local authorities, or some kind of equalisation, such as that promoted by the Metropolitan Common Poor Fund, was set on foot. Secondly, it was produced by actual differences in local administration. Differentiation of the first kind was adopted in order to introduce modifications in the incidence of the rate on the localities. It was supported on grounds of equity, or in order to put a bonus on a course of action which appeared to be of general advantage to the community, and which unaided the locality would be inclined to shirk. For instance, when the central government desired that medical officers should be appointed throughout the country, they placed a bonus on such appointments. Such a system would continue for a long period. Its purpose would be served; and then it would tend to become an anomaly. This was now the position of some Exchequer grants that may have been just and reasonable when first initiated.

As to the second kind of differentiation, that due to actual differences in local administration, he was not sure that Mr. Gomme had separated it from the other with sufficient clearness in his classification. Yet it was generically different. The one was imposed on the community with a view to the promotion of a better or a more equitable administration. The other was due to management. Being interested in matters connected with poor-relief, he had referred to the table on p. 490, where out-door relief was entered in a special service account. This seemed to take it out of the 
category of ordinary administration. Nevertheless, out-door relief was really part and parcel of the administration of poor relief, and could hardly be dissociated from all other branches of the work of poor law guardians. Accordingly he could not think it right to classify it with "open spaces" and "baths and washhouses." If it was to be fairly dealt with, it should be dealt with as a normal administrative charge, increased or reduced according to the ability or carefulness of the local administration. But from Table A, pp. 500-504, it seemed that "out relief" in the table on p. 490 included really more than "out relief." For in Col. 3 of Table A the heading was, "Out-door Relief (including Casual Wards, Houseless Poor, and Dispensary)." Was it not a pity, he asked, to bring these various items together?

To most people it would seem that the casual ward, and even the poor law dispensary served a different purpose from ordinary outdoor relief. In St. George-in-the-East, according to the tables, the percentage on rateable value under this heading was $2 l$. rs. rod., which as a normal charge for out-door relief in that union seemed to him, compared with the similar charge incurred by other unions, very large. In St. George-in-the-East the out-door relief test was a very small one. Possibly the largeness of the percentage was due to some special charges being incurred by the guardians in the year in question; that might account for the excess.

The rateable value of St. George-in-the-East in 1894 was 1 $93,878 l$., and in 1895-96 the cost of out-door relief was returned by the Local Government Board at $330 l$., which would give a much smaller percentage on rateable value than that set down in the table. Medicines were charged to the Metropolitan Common Poor Fund. So were the salaries and rations of dispensary officers. Normal out-door relief was not so charged. Was it not a pity to classify in one column items chargeable to the Metropolitan Common Poor Fund and items not so chargeable? Thus, the differentiation due to administration as against that due to equalisation was, apparently, not discriminated. He suggested that the net result of a consideration of these figures might be said to be : firstly, in regard to the Exchequer grants, that they should localise certain expenditure entirely, and thus get rid of the grants from the Exchequer in aid of local rates. Secondly, in regard to the relations between the county authority and the local or district authority, that the whole weight of responsibility as to expenditure, in regard to certain definite charges and definite administration, should fall upon the county anthority, while the whole weight of responsibility in regard to all other local charges and as to local administration should fall upon the local or district area. The end they had in view was, it seemed, to draw out from the local community the greatest interest in local administration and the strongest sense of local responsibility. That the representatives of the local community had to pay bills and consider ways and means was of course one of the chief means of education in municipal work, as it was relatively in domestic arrangements. He would ask Mr. Gomme whether or not the system of common poor fund could not be superseded by some other system, which possibly 
might not give to poorer districts the same advantages or disadvantages with regard to particular charges, but which would so allocate responsibility that local charges would be met locally, altogether without regard to doses of relief from any higher authority. The intricacies of the present system seemed infinite, and, in a great degree, unnecessary. He hoped that the statement that they had heard that evening would help towards the clearance of complexities and difficulties. If local government was to be in the best sense popular, it was essential that the methods of local taxation should be simple. The paper was a good plea for simplicity, but simplicity might require some such adjustment of charges as between the larger county authority and the local authority as he had suggested.

Mr. Noel HuMPhREYs, while thoroughly agreeing that the registration county was a statistical monstrosity, ventured to suggest that Mr. Gomme should have spoken of the poor law union county rather than of the registration county. Unfortunately with regard to registration statistics the RegistrarGeneral had been hampered for sixty years by the provisions of the Registration Act. He had been forced by these provisions to retain the poor law unions as the statistical unit, and the poor law county, which was an aggregation of unions, was the result of poor law administration-it was only an accident of registration, and therefore he suggested that the lecturer should have complained of the poor law county rather than of the registration county.

Mr. E. Cannan said he could not profess to understand London local taxation, which was much more complicated even than that of the country. But both in London and the country the whole system was based on the principle of one authority receiving money and paying it away to other authorities, till the taxpayer could not tell in the least who had spent it. With regard to the distribution of the Exchequer grant between London and the country, he noticed that Mr. Gomme attacked that on the ground that it was not quite fair according to the principle adopted ; but the principle adopted was so hopelessly absurd that really it did not very much matter: at least Mr. Gomme could not expect anyone to feel it very keenly if London got a very small fraction less than it should properly receive on that basis. The distribution should be attacked on wider grounds. At present it was a sort of inverted land-tax. Just as the land tax was collected in proportions from the various districts regardless of all changes since the original settlement, so was the estate duty grant distributed. It was an extraordinary thing that just when Chancellors of the Exchequer were trying to get rid of the remains of the land-tax, they should be basing a system of distribution on the same principle, and thus preparing infinite embarrassment for their successors.

Mr. R. Price-Williams said that the statistics showed the 
most startling inequalities. He had the consolation of thinking that although the paper had been very inadequately discussed, it would, through the medium of the press, receive the consideration which it deserved, and the unfair treatment which London suffered would be publicly brought forward, and he thought the time had come when glaring anomalies of the incidence of taxation would have to be remedied. He could only express his great regret that an opportunity could not have been afforded to have had the valuable paper beforehand, so that they could have studied it, and fairly fastened upon the main points which had been so forcibly brought forward.

Sir Juland Danvers called attention to the system of assessment that prevailed in different parishes as being unfair and irregular. It not unfrequently happened that two houses in the same street, of equal value, were assessed at different rates. There were also cases where houses had been similarly assessed, and where the owner of one appealed but the other did not. The one who appealed might get a reduction of the rate, while the other would go on for some three or four years paying the higher amount. He asked whether some more systematic system could not be adopted which would avoid the injustice and irregularities that so often occurred from the present course of procedure.

Mr. J. A. BaInes, C.S.I., said that perhaps the last question was one for a vestryman like himself to deal with elsewhere rather than for a statistical expert. The subject dealt with in the paper had already been before the London County Council for some time, and he had no doubt that it would continue to be considered there in the future. Much of the statistical matter in the paper had, as mentioned by Mr. Gomme, been presented to the Royal Commission upon Local Taxation, and Mr. Gomme had been specially complimented by Lord Balfour of Burleigh for the excellent way in which he bad marshalled his figures. There were two main questions here raised : one was the injustice to London under the present system of local taxation grants, and the other was the distribution of local burdens between local and imperial taxation. The latter point had naturally been dealt with in less detail than the former. He hoped the paper would be made use of not merely by the Statistical Society, but that it would be distributed to municipal and county officers throughout the country, in order that further criticisms might be obtained from different points of view. He might perhaps say that before the facts dealt with by Mr. Gomme had been brought before the County Council and Royal Commission, Londoners were not aware how badly they were being treated. At the same time he did not consider that the case was quite as black as it appeared upon paper. There were several items to be put per contra. He agreed that the present system of Exchequer grants was one that required revision; it was irrational and unfair, and was not profitable to many of the areas that were subject to it. He also agreed with Mr. Gomme as to the present diversity in form of demand notes in London. It was but right 
that ratepayers should be able to compare what they had to pay in different parishes, but this could not be ascertained under the system now prevailing. He instanced the demand note to which Sir Juland Danvers and he himself were subjected, as being of a peculiarly voluminous nature, but beyond the intelligence of the average prospective occupier of $20 l$. houses. As to the basis on which local taxation grants should be apportioned, no one basis could, in his opinion, be adopted. Population must in some cases be taken into account, with rateable value, rated buildings, \&c., and local expenditure, and the ratios be compounded to get the "figure of merit" for each unit. The Commission now sitting would have to give some opinion upon this subject. The whole difficulty with regard to London rested upon this, that in the legislation of 1888 it was treated as a county, when in fact it was not a county or a county borough, but an aggregate of peculiar urban circumstances, complicated by the question of the City. The time honoured customs which prevailed in the City might no doubt be ultimately brought into line with the conditions of the rest of Iondon. He thought that the financial relations between the two could very well be settled, as there was a provision in the Act of 1888 under which conferences on that subject could be held between the City and the London County Council. Such an agreement was very important in connection with the police charges. In conclusion, he proposed a hearty vote of thanks to Mr. Gomme for his comprehensive and interesting paper.

Mr. Gомме, in reply, expressed his pleasure at being present that evening to read the paper before the Society. With regard to the statement just made, to the effect that London was not a county, he might point out that an Act of Parliament said that it was, and gave it the county organisation. There was nothing mysterious in this; it was only a case of development. The subjects discussed were very important, but they might be summed up in almost a sentence. He thought Mr. Loch had put the case very clearly indeed, namely, that it was a fight now as to whether administrative bodies should have control of their taxation, or should be allowed to dip into other people's taxation. The suggestion of another speaker, that the common poor fund should be superseded by another system which would obviate the iniquities of the present dose system, went really to the root of the whole question. Administrative bodies should be responsible to their constituencies for the taxation which was caused by their administration. But there were some local services which were so far nationalised that they might be with safety transferred to the national government to be paid for out of the national taxes. On the other hand there were some which could be properly transferred from local to county administration and taxation. As an example of the latter he might refer to lunacy, which had become a county charge, but by the most cumbersome machinery imaginable. Upon the whole, he thought Mr. Loch had laid stress apon the important lesson which might be learnt from the paper. $\mathrm{He}$ quite agreed with Mr. Humphreys that he should have said "poor 
law county;" but it was one of those pieces of stupidity of modern legislation that registration should have been placed in the hands of poor law authorities; really it had nothing to do with poor law. Poor law authorities at that time were the most prominent of local authorities, and accordingly they were entrusted with the administration. If things were properly adjusted a great deal of expense could be got rid of with the greatest ease. Mr. Cannan had objected to his criticism of the London case against the system of allocating Parliamentary grants, because the principle was so bad that any small damage to any particular locality was not of very great importance; but he happened to be dealing with London taxation, and therefore thought a small matter was well worthy of being brought before that Society. One of his points about the present system was that if it were a rough and ready method of doing justice, and if practically justice were done, you might shrug your shoulders and say that although it was a stupid way of doing justice, still justice was done. But he contended that it did not effect the desired end, and therefore he thought the detailed criticism was of some importance. With regard to the suggestion that a new basis was required which should take into consideration the question of rateable value, population, and expenditure, he did not think that any system of doling from the central authority to a local authority was a good one. In fact he thought it was vicious and bad in the extreme, and any basis by which an artificial area-grouping of a tax collected nationally seemed to be one of those kind of things which could only be defended by proof that the use of a rough and ready method attained a good result. That it did not do, as it relieved owners of property of their due share of taxation. This was sought to be adjusted by alterations in the system of imperial taxation. The only possible way of dealing with the subject was to let, local taxation pay for local purposes, and for that purpose transfer to local purposes such taxation now included in imperial taxation as really was local, and transfer to imperial administration and taxation such services as had outgrown their local character and had become national. 